Zabytkoznawstwo i Konserwatorstwo XXXVIII, Toruń 2010

Teresa Łękawa-Wysłouch

Uniwersytet Mikołaja Kopernika w Toruniu

\title{
Badania materiałów stosowanych do uzupełniania ubytków zapraw w malowidłach na płótnie
}

\section{Wprowadzenie}

Z agadnień związanych z uzupełnianiem ubytków zapraw nie można uznać za temat wyczerpany i zamknięty, mimo bogatych doświadczeń kilku pokoleń konserwatorów. W codziennej pracy konserwatora-restauratora rodzi się wiele pytań związanych z tą problematyką, np. jaka jest trwałość i możliwości usunięcia z konserwowanego obiektu współczesnych środków; czy słuszne jest uzupełnianie ubytków masami, których skład i właściwości znacznie różnią się od zapraw oryginalnych? Zastanawia też fakt stosowania identycznych pod względem receptury kitów do wypełniania ubytków zapraw na, tak różniących się, podłożach tekstylnym i drewnianym. Ideałem byłoby istnienie uniwersalnej, wolnej od wad receptury, jednakże prowadzone od lat badania formułuja jednoznaczną opinie, że receptura, która spełniałaby wszystkie wymagania stawiane kitom, nie została opracowana. Ponadto w handlu pojawiają się wciąż nowe, gotowe preparaty, których główną zaletą jest łatwość użycia, niewymagająca czasochłonnego przygotowywania masy o złożonym składzie. Producenci nierzadko polecają swoje produkty jako spełniające wszelkie wymagania stawiane im przez konserwatorów.

* Artykul powstał na podstawie pracy magisterskiej wykonanej przez autorke pod kier. prof. dr Marii Roznerskiej w Zakładzie Konserwacji Malarstwa i Rzeźby Polichromowanej Instytutu Zabytkoznawstwa i Konserwatorstwa UMK w Toruniu w 1999 r. 
Perspektywa przyspieszenia i ułatwienia pracy skłania niekiedy konserwatora do siegnięcia po gotowy preparat i bezkrytycznego zaufania do producenta, bez oglądania się na publikacje fachowe (które, notabene, nieczęsto towarzyszą wprowadzanym i upowszechnianym środkom). Ich brak powoduje, że nie jest możliwe zapoznanie się z charakterystyką i właściwościami produktu przed zastosowaniem go. Zwykle też wytwórcy strzegą receptury tajemnicą handlową i skład materiałów firmowych nie jest ujawniany. Wobec powyższego niemożliwe jest określenie warunków, w jakich środki te mogą być stosowane, a co gorsza, także określenie ich trwałości i odwracalności.

Celem podjętej pracy było przebadanie i ustalenie zespołu właściwości fizykochemicznych kilku kitów fabrycznych oraz komponowanych przez konserwatorów, a także sprawdzenie ich przydatności w konserwacji malarstwa sztalugowego na podłożu płóciennym. Przeprowadzone specjalistyczne badania laboratoryjne pozwoliły na określenie podstawowego składu chemicznego kilku gotowych produktów, co w praktyce ułatwi ich ocenę i umożliwi ewentualne modyfikacje.

Do badań wytypowano nastepujące gotowe preparaty:

1. Kit Spakelli Pukitti, zwany dalej kitem Tikkurila. Produkt firmy Tikkurila - Finlandia, przedstawicielstwo - TECH PRO-impex, Sopot;

2. Kit Italstucco. Produkt firmy Ditta F. Follador - Mediolan, Włochy;

3. Kit Modostuc. Produkt firmy Plasvero S.p.A. - Vellezzo Bellini, Włochy;

4. Kit BEVA® Gesso-P oraz

5. Kit BEVA® Gesso- $V$. Produkty CPC Conservators Products Company - USA, przedstawicielstwo - PP-U Restauro-Technika, S. Przedpełski J. Wieliński Sp.c. Torun.

Jako materiały porównawcze wybrano dwa kity sporządzane według receptur:

6. Kit emulsyjny, tzw. „wiedeński”, o następującym składzie i proporcjach:

15\% roztwór wodny polialkoholu winylu - 1 część wagowa,

3\% roztwór wodny metylocelulozy - 1 część wagowa,

kreda szampańska - 3,5 części wagowe,

25\% mastyks w olejku terpentynowym - 0,3 części wagowe, terpentyna wenecka - 0,15 części wagowe. 
7. Kit modyfikowany klejowo-kredowy, reprezentujący grupe materialów z udziałem tradycyjnego spoiwa, kleju glutynowego. Za podstawę receptury posłużył przepis podany przez Slanskiego, o składzie zmodyfikowanym terpentyną wenecką, mającą za zadanie poprawienie cech tradycyjnego kitu klejowo-kredowego. Skład kitu:

10\% roztwór kleju króliczego - 1 część wagowa, wypełniacz - 3 części wagowe, o następującym składzie i proporcjach:

kreda szampańska + kreda bolońska - 3:1, terpentyna wenecka - 0,2 części wagowe.

Przeprowadzono następujące badania (w których poszczególnym kitom przyporządkowano powyższe numery):

1. Składu chemicznego - metodą termicznej analizy różnicowej (z użyciem derywatografu) oraz metodą spektroskopii absorpcyjnej w podczerwieni ( $z$ użyciem aparatu Specord 75 IR), które pozwoliły na identyfikację i określenie ilościowej zawartości podstawowych składników - spoiw i wypełniaczy.

2. Łatwości użycia, przygotowania i wszelkich cech, mających związek z aplikowaniem kitów: ich plastyczności, lepkości, konsystencji, wyglądu, twardości i możliwości opracowywania powierzchni utworzonych przez wyschnięte kity, a także możliwości modyfikacji pozwalających na dostosowanie do indywidualnych wymagań obiektu, zdolności wysychania - tj. czasu odparowania rozpuszczalników z materiałów.

3. Przydatności do odciskania faktur na powierzchni wypełnienia za pomoca negatywowych form z Aralditu CY 221 oraz z kauczuku silikonowego.

4. Zmian objętości podczas wysychania materiałów naniesionych w różnych grubościach na podłoże płócienne; skurczu, powstawania spekkan - określone na podstawie analizy wizualnej.

5. Przyczepności materiałów (adhezji) do podłoża płóciennego przeklejonego metylocelulozą (imitującego reperacje lokalne) oraz do płótna przesyconego masą woskowo-żywiczną (imitującego podłoża konserwowane z użyciem tego spoiwa) - badania na zrywarce, określające siłę powodującą naruszenie stabilności układu kit-płótno. 
Badania uzupełniono porównawczą oceną prób całkowitego odrywania kitów od płótna przez mechaniczne podważanie krawędzi próbek z użyciem skalpela.

6. Wartości określających kwasowość (pomiar pH) materiałów świeżych niezwiązanych oraz po ich związaniu i sezonowaniu (po przeprowadzeniu jonów wodorowych do roztworu wodnego) - z użyciem pH-metru typu N 512 Lic Polymetron MERA-ELMAT.

7. Elastyczności kitów naniesionych w jednakowych grubościach na podłoże płócienne i wyginanych na walcach o różnej średnicy. Zbadano tę właściwość materiałów w zróżnicowanych warunkach wilgotności względnej i temperatury powietrza, określając istnienie zależności elastyczności od tych parametrów.

8. Higroskopijności - zdolności do pochłaniania przez materiały pary wodnej - w warunkach podwyższonej wilgotności powietrza na próbkach kitów uformowanych w kształtki oraz naniesionych na szkiełka przedmiotowe w warstwach o jednakowej grubości.

9. Chłonności i zwilżalności powierzchni kitów przez wodne spoiwo farb - właściwości determinujące pomyślność i trwałość barwnych uzupełnień warstwy malarskiej - na próbkach wyszlifowanych nieizolowanych kitów, na próbkach pokrytych werniksem retuszerskim, a także na próbkach werniksowanych i zwilżonych żółcią wołową. Wszystkie próbki były naniesione w jednakowej grubości na szkiełka przedmiotowe.

10. Przyczepności powłok utworzonych przez akwarelowe i akrylowe farby o wodorozcieńczalnym spoiwie, stosowane do uzupełniania ubytków barwnych warstw malarskich. Badanie wykonano według normy PN-73/C-81531 za pomocą noża krążkowego na powłokach farb naniesionych na wyszlifowane i werniksowane próbki kitów na podłożu szklanym.

11. Odporności na atak mikrobiologiczny w warunkach podwyższonej wilgotności - na próbkach kitów naniesionych na szkiełka przedmiotowe i przechowywanych w cieplarce przez sześć miesięcy.

12. Odporności na starzenie w skrajnych warunkach temperatury i wilgotności powietrza - próbki założone na różnych podłożach płóciennych - nowym płótnie przeklejonym metylocelulozą, starym 
płótnie z wyekstrahowanym spoiwem dublażowym i przeklejonym metylocelulozą, starym płótnie dublażowym przesyconym masą woskowo-żywiczną oraz kity wprowadzone w ubytki zaprawy we fragmentach destruktu XVII-wiecznego obrazu - poddano w dwóch etapach działaniu skrajnych warunków temperaturowo-wilgotnościowych, umieszczając je w szafie klimatycznej (I etap - wysokie temperatury i niskie wilgotności) oraz w komorze wilgotnościowej (II etap - średnie temperatury i wysokie wilgotności). Łączny czas trwania badań wynosił pięć miesięcy.

13. Odwracalności - możliwości usunięcia kitów z obiektów po kilkumiesięcznym okresie starzenia w skrajnych warunkach temperatury i wilgotności - przetestowano metody mechaniczne i chemiczne.

\section{Charakterystyka materiałów użytych do badań}

\subsection{Charakterystyka kitu Spakkeli Pukitti na podstawie informacji producenta}

Produkt firmy Tikkurila - Finlandia.

Szpachlówka akrylowa do wyrównywania ubytków w drewnianych powierzchniach we wnętrzach (meblach, drzwiach, stropach, podłodze, boazerii itp.). Rozpuszczalna w wodzie, po wyschnięciu wodoodporna, odporna także na kwasy i zasady. Występuje w kilku kolorach: biały, czarny, mahoń, sosna, brzoza, dąb, buk.

Dane techniczne:

- masa stała: $67 \%$,

- gestość: $1,8 \mathrm{~kg} / 1$,

- czas wysychania w temp. $23^{\circ} \mathrm{C}$ i RH 50\%: cienka warstwa kitu może być szlifowana po upływie ok. 4 godzin, głębsze ubytki po 24 godzinach;

- opakowania: 1/31, 11, 101.

Kit należy nakładać za pomocą szpachelki na suchą powierzchnię, większe ubytki wypełniać dwu- lub kilkakrotnie. Jeśli to konieczne, można go rozcieńczyć wodą. Powierzchnia może być lakierowana lub werniksowana. 
Kit nieodporny na przemarzanie - temperatura powietrza przy aplikowaniu powinna wynosić co najmniej $+5^{\circ} \mathrm{C}$.

\subsection{Charakterystyka kitu Italstucco - stucco bianco per legno e muri na podstawie informacji producenta}

Produkt firmy Ditta F. Follador - Mediolan, Włochy.

Do produktu nie jest dołączona żadna ulotka. Podstawowe, skąpe informacje w języku włoskim są umieszczone na pojemniku, w którym kit jest konfekcjonowany. Według tych danych Italstucco jest białą szpachlówką przeznaczoną do wypełniania ubytków w materiałach porowatych, jak mury i drewno (tynki, ściany, podłogi, meble, boazerie itp.).

Szpachlówka jest materiałem łatwym w użyciu i szybko wysychającym. Może być rozcieńczana wodą i nakładana pędzlem. Po wyschnięciu stanowi dobre podłoże pod wszelkie farby. Znosi obciążenia do $100 \mathrm{~kg} / \mathrm{cm}^{2}$.

\subsection{Charakterystyka kitu Modostuc - stucco speciale per legno e muro na podstawie informacji producenta}

Produkt firmy Plasvero S.p.A. - Vellezzo Bellini, Włochy.

Modostuc w paście jest specjalnie sporządzonym kitem do profesjonalnego użytku, idealnym do pokrycia jakichkolwiek nierówności i defektów w drewnie i ścianie. Jego skład jest nastepujący:

- żywica: wodna dyspersja polioctanu winylu (50\%); 1,5-3\% stałej masy,

- środki konserwujące: 0,08-0,11\%,

- wypełniacze: weglan wapnia 65-70\%, siarczan baru 12-33\% (ogólem 96-98\%),

- dodatki: nitrobenzen 0,02\%,

- pigmenty (tlenki żelaza - żółty, czerwony, czarny - dotyczy kitów barwnych): 0-4,5\%.

Kit ma następujące właściwości:

- gęstość: 1,85-1,95 g/ml,

- masa stała: 78\%,

- lepkość: wysoka. 
Zapewnia doskonała powierzchnię do malowania emalią i farbami o wodnym spoiwie emulsyjnym. Jest łatwy w nakładaniu, szybkoschnący i zupełnie pozbawiony zapachu. Produkt nie zawiera toksycznych i niebezpiecznych substancji, jest niepalny, odwracalny w razie potrzeby, nierozpuszczalny w wodzie. Występuje w dziesięciu kolorach: biały, kość słoniowa, dąb, orzech włoski, ciemny orzech włoski, jasna sosna, daglezja, mahoń, palisander oraz teak. Przy przechowywaniu w pomieszczeniu o temperaturze między +5 a $+40^{\circ} \mathrm{C}$ i szczelnym zamknięciu pojemnika stabilny i przydatny do użycia przez okres trzech lat. Nie poleca się stosowania na niesezonowane drewno. Sposób nakładania - za pomocą giętkiej, stalowej lub plastikowej szpachelki. Grube warstwy można uzyskiwać przez sukcesywne aplikowanie kitu. Występuje w opakowaniach: $1 / 4 \mathrm{~kg}$ (tylko biały), $1 / 2 \mathrm{~kg}, 1 \mathrm{~kg}, 5 \mathrm{~kg}, 25 \mathrm{~kg}$.

Centralne Laboratorium Badawcze w Amsterdamie w 1991 roku przeprowadziło badania składu kitu Modostuc metodą spektroskopii w podczerwieni (FTIR - Fourier Transform Infrarood Spectroscopie). W ich wyniku stwierdzono w składzie kitu obecność węglanu wapnia, polioctanu winylu, estru akrylowego i śladowych ilości kaolinu ${ }^{1}$.

\subsection{Charakterystyka kitów BEVA® Gesso-P i BEVA® Gesso- $V$ na podstawie informacji producenta}

Produkty CPC Conservators Products Company - USA, przedstawicielstwo - PP-U Restauro-Technika, S. Przedpełski J. Wieliński Sp.c. Toruń.

Kit BEVA® Gesso jest zagęszczoną kombinacją chemicznie obojętnego mineralnego pudru, buforu $\mathrm{pH}$, inhibitora utleniania, stabilizatora UV i żywic BEVA. Kity zawierają mineralny wypełniacz o granulacji drobnej (BEVA ${ }^{\circledR}$ Gesso-P) lub średniej (BEVA ${ }^{\circledR}$ Gesso-V). Zastosowane wypełniacze są krystalicznymi materiałami o wysokiej porowatości (a co za tym idzie o podwyższonej objętości i niskiej gęstości). Wypełniacz jest nierozpuszczalny w wodzie, a jego zdolność absorpcji wody wynosi poniżej 1\% - jest przekształcony w gliniastą mase, jak gips modelarski, urabianą rękami.

1 Informacje te i wyniki badań uzyskano dzięki uprzejmości Pani Gwenn Tauber, konserwatora dzieł sztuki, pracującej w Rijksmuseum w Amsterdamie. 
Kity mają następujące własności:

- wysoka elastyczność i odporność na rozszerzanie i kurczenie materiału na skutek wahań atmosferycznych lub wibracji podczas transportu,

- $\quad$ szeroki zakres elastyczności, którą dodatkowo może jeszcze zwiększyć niewielki dodatek BEVA 371,

- stabilność (przewidywalne zachowanie właściwości przez ok. 100 lat), nieuleganie rozkładowi podczas przechowywania w zamkniętym słoiku lub puszce, możliwość reaktywowania stwardniałego kitu na obiekcie i w magazynowaniu toluenem, ksylenem lub w niskoaromatycznych ropopochodnych rozpuszczalnikach,

- dobra przyczepność do różnych materiałów (tektura, tkanina, drewno, ceramika, plastik, metal i farby) przy równoczesnym niewchodzeniu z nimi w reakcje,

- gotowość do użycia w każdej chwili, możliwość nakładania prosto z puszki (nie wymaga wstępnego ogrzania) i opracowywania na mokro, sucho, z ogrzaniem $\left(65-70^{\circ} \mathrm{C}\right)$, a także pod ciśnieniem, co pozwala na odciskanie różnych faktur, uzyskanie gładkiej, a nawet połyskliwej powierzchni, imitującej różne materiały,

- BEVA® Gesso-P schnie na biało, a BEVA® Gesso- $V$ na beżowo, w krótszym czasie niż kity olejowe lub klejowe. Istnieje możliwość barwienia kitów przez dodatek suchych pigmentów, olejnych lub alkoholowych farb Maimeri (w mniejszym stopniu także wodnych),

- kompatybilność z większością mediów do retuszu (wodne emulsje akrylowe, Paraloid B-72, werniksy, politura francuska, olej chiński), możliwość stosowania retuszy bezpośrednio na suchych wypełnieniach (nie jest absorbentem),

- jest zbuforowany do utrzymania niekwasowego $\mathrm{pH}$,

- prawie całkowita niezmienność wymiarów po wyschnięciu,

- całkowita odwracalność w podwyższonej temperaturze lub w niskoaromatycznych weglowodorowych rozpuszczalnikach.

Jak podaje producent, kity BEVA ${ }^{\circledR}$ Gesso były testowane w laboratorium prof. Domingo IsaacaTellechea w São Paulo w Brazylii. Przeprowadzone badania przyspieszonego starzenia poprzez ekspozycje na promieniowanie radiacyjnej lampy Xenonowej o mocy 5000 W w cyklach 60 minut naświetlania 
i 6 godzin nawilżania, które odpowiadały około 15 latom normalnego starzenia, nie ujawniły w badaniu rentgenowskim zmian w materiale. W 1993 roku kit BEVA ${ }^{\circledR}$ Gesso został zastosowany w restauracji pięciu monumentalnych płócien $(8,9 \mathrm{~m} \times 5,5 \mathrm{~m})$ Joségo Maria Berta, które poważnie ucierpiały podczas bombardowań Ambasady Izraelskiej w Argentynie. Kity nie przeszkadzały w zwijaniu obrazów na walce, podwieszaniu do sufitu, napinaniu i odrywaniu płócien. Zdaniem prof. Tellechea, zastosowanie BEVA ${ }^{\circledR}$ Gesso ułatwiło retusze i zredukowało ich pracochłonność do około 70\%.

\subsection{Charakterystyka kitu emulsyjnego, tzw. „wiedeńskiego”}

Receptura kitu emulsyjnego „wiedeńskiego” została uzyskana około połowy lat 70. XX wieku w pracowni konserwatorskiej w Wiedniu przez mgr. Ziemowita Michałowskiego i przywieziona do Polski, do Zakładu Konserwacji Malarstwa i Rzeźby Polichromowanej UMK w Toruniu², gdzie stała się przedmiotem badań i obserwacji. Jak podaje M. Wiciejowska-Stankiewicz ${ }^{3}$, która uzyskała ją do swej pracy od mgr. Michałowskiego, oryginalna receptura kitu zawierała żywicę Alkydale - zmodyfikowaną żywicę alkidową (Bayer, RFN). Trudno dziś ustalić w szczegółach pierwotny skład i proporcje składników, gdyż przez blisko trzydzieści lat receptura kitu kilkakrotnie ulegała zmianom, co było wynikiem dążenia do udoskonalenia właściwości, a także licznych modyfikacji, mających na celu dostosowanie do indywidualnych wymagań obiektów. Liczne ślady tych działań można odnaleźć w dokumentacjach konserwatorskich obrazów, których konserwacje wykonano w ZKMiRP UMK w Toruniu. Jakkolwiek od samego początku receptura bazowała na połączeniu składników naturalnych z syntetycznymi. Na polskim gruncie zawiera: metyloceluloze, polialkohol winylowy (lub zamiennie żelatynę), mastyks, terpentynę wenecką i kredę lub pigmenty. Modyfikacje polegały na zmianach stężenia i proporcji poszczególnych materiałów, a także

2 Informacja ustna przekazana przez prof. dr M. Roznerską.

3 M. Wiciejowska-Stankiewicz, Kity w obrazach na płótnach przesyconych woskiem, maszynopis pracy magisterskiej napisanej pod kier. doc. Z. Wolniewicz w ZKZR UMK, Toruń 1978, przypis 7 , s. 30. 
na stosowaniu różnych gatunków wypełniaczy. Zamieszczony poniżej zarys stanu badań opracowano na podstawie ustaleń prac magisterskich, które zajmowały się badaniem kitu emulsyjnego „wiedeńskiego”, oraz informacji zamieszczonych w dokumentacjach konserwowanych obrazów.

Po raz pierwszy kit emulsyjny „wiedeński” został włączony do badań przeprowadzonych przez B. Tańską w 1977 roku i zawierał:

$4 \%$ metyloceluloze,

10\% żelatynę (spoiwa w stosunku 1:1, jednak bez proporcji wobec pozostałych składników),

2-3 części kredy,

25-30\% terpentynę wenecką (bez odnotowania proporcji) ${ }^{4}$.

Autorka oceniła, że kit charakteryzuje się łatwością zakładania i obróbki, dobrą przyczepnością do płótna przeklejonego żelatyną oraz przewoskowanego, dobrą elastycznością, na którą nie mają znacznego wpływu zmiany wilgotności powietrza, a także dobrą zwilżalnością przez wodę i zadowalającą adhezją retuszy ${ }^{5}$. Spośród pięciu przebadanych w pracy kitów to właśnie „wiedeński” uzyskał najwyższą ocenę. Autorka postuluje opracowanie kilku wariantów receptury, opierając się na modyfikacjach dostępnych materiałów ${ }^{6}$.

Zapewne opinia ta miała wpływ na fakt, że już po upływie roku kit został ponownie poddany badaniom pod katem zastosowania w obrazach na płótnach przesyconych woskiem ${ }^{7}$. Prowadząca te badania M. Wiciejowska-Stankiewicz podaje już zmienioną, a zarazem nieco bardziej precyzyjną recepturę:

3\% metyloceluloza - 1 część,

15\% żelatyna lub polialkohol winylu (nie precyzuje, które ze spoiw użyto) - 1 czesść,

kreda lub pigment (czerwień żelazowa lub umbra palona) - 2 części,

4 B. Tańska, Kity na podłożu tekstylnym, maszynopis pracy magisterskiej napisanej pod kier. doc. Z. Wolniewicz w ZKZR UMK, Toruń 1977, s. 17.

5 Ibidem, s. 39.

6 Ibidem, s. 42.

7 M. Wiciejowska-Stankiewicz, op. cit. 
30\% mastyks w olejku terpentynowym i terpentyna wenecka - obie żywice w ilościach, jak podaje autorka, na końcu łyżeczki do herbaty (nie określając, na jaką ilość masy).

Kity zostały przygotowane $\mathrm{w}$ wersjach: $\mathrm{z}$ wypełniaczem kredowym, z tym samym wypełniaczem izolowane $15 \%$ Paraloidem w toluenie, z wypełniaczem pigmentowym. Kit „wiedeński” badany w zestawieniu z dwoma kitami: woskowo-żywicznym i na bazie spoiwa BEVA 371, ponownie uzyskał najwyższą ocenę. Autorka podkreśla jego dobrą elastyczność w warunkach normalnych i po nawilżeniu, dobrą adhezję do przewoskowanego podłoża, możliwość nakładania różnymi narzędziami w grubszych i cieńszych warstwach oraz szlifowania na sucho skalpelem i na mokro korkiem lub szmatką, a także opracowywania faktury przez rysowanie ostrym narzędziem w zwilżonej powierzchni kitu. Przyczepność retuszy wykonanych farbami akrylowymi, akwarelowymi i olejnymi do kitu ocenia jako dobrą. Zaleca izolacje kitu 15\% Paraloidem w toluenie lub szelakiem przed rozpoczęciem punktowań, z powodu „lekkiej chłonności kitu”. Wyniki uzyskane przez autorkę świadczą o tym, że nieco gorsze właściwości mają kity z wypełniaczem pigmentowym - zarówno pod względem elastyczności po przesuszeniu kitów, jak i przyczepności powłoki retuszów do powierzchni kitów ${ }^{9}$. W końcowej konkluzji badaczka stwierdza, że właściwości kitu „wiedeńskiego” pozwalają na zastąpienie nim tradycyjnych kitów woskowych ${ }^{10}$.

W latach 80. XX wieku ustalił sie, funkcjonujący do niedawna, podstawowy skład kitu emulsyjnego „wiedeńskiego”, co ma potwierdzenie w dokumentacjach obrazów konserwowanych w tym czasie w ZKMiRP w Toruniu. Dobra opinia, jaką kit nadal się cieszy, sprawia, że podejmowane są próby zastosowania go na innych podłożach niż dotychczas sprawdzone płócienne i drewniane. Ewa Kuśnierz ${ }^{11}$ w 1986 roku włączyła go do badań materiałów

8 Ibidem, s. 28.

9 Ibidem, s. 18-23.

10 Ibidem, s. 29.

11 E. Kuśnierz, Materiały służące do uzupełniania ubytków zaprawy i warstw malarskich w obrazach na podobraziach metalowych, maszynopis pracy magisterskiej napisanej pod kier. doc. dr M. Roznerskiej w ZKMiRP UMK, Toruń 1986. 
do uzupełniania ubytków zaprawy i warstw malarskich na podobraziach metalowych. Receptura kitu jest tu następująca:

15\% polialkohol winylu - 1 część wagowa,

3\% metyloceluloza - 1 cześć wagowa,

kreda pławiona - 2-3 części wagowe,

25\% mastyks w olejku terpentynowym - 0,2-0,4 części wagowe,

terpentyna wenecka - 0,1-0,2 części wagowe.

Wyniki badań pokazały jednak, że mieszanina ta nie jest odpowiednia do stosowania na podobrazie metalowe. Badany na płytkach metalowych kit wykazał słabą przyczepność do podłoża, niską elastyczność, a przede wszystkim niekorzystne oddziaływanie na podłoże. Z powodu zawartości wody kit inicjuje i stymuluje procesy korozyjne, w wyniku których następuje przebarwienie wypełnienia produktami korozji, dezintegracja - aż do utraty spójności kitu z podłożem ${ }^{12}$.

W tym samym roku kit „wiedeński”, o identycznym jak wyżej składzie, został też przebadany pod kątem przydatności do odciskania faktur za pomocą form negatywowych przez D. Nowacką ${ }^{13}$. Autorka zwraca uwage, że kit ten wysycha bardzo twardo, a po kilkunastu minutach traci właściwości plastyczne, co sprawia, że odciskanie faktury musi być wykonywane stosunkowo szybko (w ciągu kilku minut od nałożenia). Przy zachowaniu tego rygoru kit daje możliwości bardzo dobrego i dobrego odwzorowania faktury podczas zastosowania negatywowych form z elastycznych tworzyw ${ }^{14}$.

Zagadnieniem przydatności materiałów do konserwacji obrazów na płótnie eksponowanych w ekstremalnych warunkach zajmowała się w 1998 roku A. Markowska ${ }^{15}$, badając też kit „wiedeński” w grupie materiałów do uzupełnień ubytków zaprawy. Kity były naniesione na płótna przeklejone

12 Ibidem, s. 82.

13 D. Nowacka, Problematyka opracowywania faktur w kitach stosowanych do uzupełnień ubytków malowideł sztalugowych, maszynopis pracy magisterskiej wykonanej pod kier. doc. dr M. Roznerskiej w ZKMiRP UMK, Torun 1986.

14 W tym przypadku autorka uzyskała takie wyniki, stosując modele z Aralditu CY 221 i z kauczuku silikonowego Polastosil M-69. Ibidem, s. 88.

15 A. Markowska, Materiały do konserwacji obrazów na płótnie eksponowanych w ekstremalnych warunkach, maszynopis pracy magisterskiej wykonanej pod kier. prof. dr B. Rouby w ZKMiRP UMK, Toruń 1998. 
żelatyną oraz Paraloidem B-72, a także na płytki szklane. Kit „wiedeński” we wszystkich badaniach wykazał dużą odporność na działanie czynników zewnętrznych. Na płótnie zaimpregnowanym Paraloidem B-72 odznaczył się największą odpornością, elastycznością i brakiem tendencji do odspojeń i spękań ${ }^{16}$.

Z analizy zapisów dotyczących kitu emulsyjnego „wiedeńskiego”, znajdujących się w dokumentacjach konserwatorskich obrazów, wynika, że nazywano tak mieszaniny różniące się między sobą składem, stężeniem, proporcjami, a co za tym idzie - także właściwościami. Niestety rzadko autorzy podawali uwagi, określające własności stosowanych przez nich mas kitujacych - a jeśli już, to bardzo ogólnikowe. Często także zamieszczane receptury są nieścisłe i nieprecyzyjne do tego stopnia, że sporządzenie kitu na ich podstawie byłoby niemożliwe.

W podawanych recepturach stężenia spoiw oscylują dla metylocelulozy między $1 \%$ a 4\%, dla polialkoholu winylu między 7\% a 20\%, a dla żelatyny, używanej zamiennie z PAW, między 10\% a 15\%. Poszczególne spoiwa stosowano w ilościach od 0,5 do 3 cześci, w stosunku wzajemnym 1:1 lub z przewagą ilościową jednego z nich. Niekiedy rezygnowano z łączenia dwóch spoiw, zwiększając ilość lub stężenie samego PAW lub MC. Stężenia mastyksu (niekiedy zastępowanego damarą) w olejku terpentynowym wahają się między 20\% a 40\%, ilości żywicy od kilku kropel do 0,5 cześci wagowych, natomiast ilości wypełniacza między 2 a 4 cześciami wagowymi. Jako wypełniacze były stosowane kredy: pławiona, szampańska, strącana, bolońska, mielona i szkolna; białe pigmenty: bolus biały, biel cynkowa, biel tytanowa, talk; kolorowe pigmenty (najcześciej ziemne): siena palona, ugier, czerwień żelazowa, umbra palona, czerń kostna - występujące samodzielnie lub łączone ze sobą.

Ta mnogość materiałów daje potencjalne możliwości uzyskania kitów o szerokiej gamie właściwości. Każde zastapienie jednego materiału innym - nawet w ramach jednej receptury - skutkuje zmianą właściwości sporządzonego kitu, gdyż różne są właściwości poszczególnych jego składników ${ }^{17}$.

16 Ibidem, s. 44. Pozostałe badane kity to: Gesso akrylowe z kreda, kit kredowy na bazie BEVA 371, trzy kity woskowo-żywiczne.

17 Na przykład inną higroskopijnością charakteryzują się pigmenty ziemne, inną biel cynkowa, jeszcze inną kreda, i to w zależności od gatunku. To samo dotyczy spoiw. 
Powodów tej różnorodności wariantów receptury należy szukać, z jednej strony, w dążeniu do ulepszania jej składu i właściwości, ale też, w pewnej mierze, sytuacja ta jest odbiciem problemów z dostępnością dobrych gatunkowo materiałów.

Spośród najczęściej sygnalizowanych wad kitu „wiedeńskiego” można wymienić: niewystarczającą elastyczność, dużą sztywnośći pękanie na krawędziach krajek po nabiciu obrazu na krosna. Problemy te były rozwiązywane na kilka sposobów: przez modyfikacje podstawowego składu kitu zwiększoną ilością spoiwa (najcześciej zwiększenie ilości metylocelulozy ${ }^{18}$ ), miękkich żywic naturalnych (głównie terpentyny weneckiej lub mastyksu ${ }^{19}$ ), modyfikacje dodatkami balsamów (balsamu kanadyjskiego) lub niewielkich ilości gliceryny czy 50\% polioctanu winylu albo też przez równoczesne zwiększenie udziału jednego lub dwóch składników i dodatek plastyfikatora ${ }^{20}$. Próba poprawienia elastyczności kitu przez zastosowanie talku jako wypełniacza okazała się niefortunna, gdyż spowodowało to poważne problemy z doczyszczaniem warstwy malarskiej ${ }^{21}$. Przyczyną jest drobnocząsteczkowa budowa talku (źródłem podobnych problemów może też być biel tytanowa). Modyfikacje składu nie zawsze przynosiły pożądany efekt, dlatego też niekiedy ponownie uzupełniano ubytki zaprawy kitem o podstawowym składzie po przełamaniu krajek i naciągnięciu obrazu na krosna ${ }^{22}$. Jednak najcześciej - zwłaszcza w drugiej połowie lat 70. i w latach 80. - eliminowano ten problem przez

18 Przykład zastosowania: zwiększenie ilości metylocelulozy do 1,5 części wag., w: L. Tymińska, Dokumentacja konserwatorska obrazu Pejzaż bagienny, nr inw. ZKMiRP 894, Toruń 1995/1996.

19 Przykład zastosowania: zwiększenie ilości mastyksu do 0,5 części wag., w: D. Raczkowska, Dokumentacja konserwatorska obrazu Portret Felicjana Karnickiego, nr inw. ZKMiRP 683, Toruń 1990. Autorka dodatkowo zastosowała zabezpieczenie krajek przez zaklejenie ich dwiema warstwami bibułki japońskiej na 7\% PAW.

20 Przykład zastosowania: zwiększenie ilości metylocelulozy, terpentyny weneckiej i dodatek gliceryny, w: U. Lis, Dokumentacja konserwatorska obrazu Choragiew cechu kuśnierzy, nr inw. ZKMiRP 156, Toruń 1984.

21 M. Świerkocka, Dokumentacja konserwatorska obrazu Portret nieznanej kobiety, nr inw. ZKMiRP 467, Toruń 1986. Autorka odnotowuje, że przeprowadzała czyszczenie lica ośmiokrotnie.

22 Przykład zastosowania w: J. Arszyńska, Dokumentacja konserwatorska obrazu Wizja Św. Bernarda, nr inw. ZKMiRP 624, Toruń 1988. 
zastosowanie na krawędziach obrazu innego kitu o większej elastyczności zwykle woskowo-żywicznego ${ }^{23}$. W latach 90. w celu uelastycznienia kitu „wiedeńskiego” przeprowadzano impregnację kitów założonych na krajkach 10\% roztworem BEVA 371 w benzynie lakowej ${ }^{24}$.

Innym zagadnieniem wyłaniającym się z analizy dokumentacji, związanym ze stosowaniem kitu „wiedeńskiego”, są problemy z uzyskaniem odpowiednio zaizolowanej powierzchni kitu pod uzupełnienia barwne. Autorzy wzmiankują o wielokrotnym nanoszeniu werniksu retuszerskiego w celu zlikwidowania efektu matowości kitów: najcześciej partie matowych wypełnień są lokalnie kilkakrotnie werniksowane tym samym werniksem, który jest użyty do pokrycia całej warstwy malarskiej ${ }^{25}$. Inne stosowane rozwiązania polegają na, poprzedzającym werniksowanie, izolowaniu kitów $10 \%$ alkoholowym roztworem szelaku ${ }^{26}$ lub $1-3 \%$ roztworem wodnym metylocelulozy ${ }^{27}$.

Problemem wspominanym kilkakrotnie przez autorów konserwacji jest deformacja płótna w wyniku reakcji wrażliwego podobrazia na wilgoć, wprowadzoną wraz z nakładanym kitem lub dodatkowo podczas opracowywania na mokro oraz odciskania faktury w zwilżonym kicie. Jeśli woda powodowała

23 Przykłady zastosowania w: M. Gawłowska, Dokumentacja konserwatorska obrazu Portret duchownego z Muzeum Narodowego w Szczecinie, nr inw. ZKMiRP 466, Toruń 1982. Autorka zastosowała kit woskowo-żywiczny na krawędziach; J. Mowińska, Dokumentacja konserwatorska obrazu Stary Żuraw w Gdańsku, nr inw. ZKMiRP 897, Toruń 1996. Autorka na krajkach zastosowała kit poliakrylowy z 50\% Primalu AC33 z kredą w stosunku 1:3.

24 Przykład zastosowania w: W. Kakareko, Dokumentacja konserwatorska obrazu Chrystus Zmartwychwstały, nr inw. ZKMiRP 868, Torun 1995.

25 Przykład zastosowania w: I. M. Malarska, Dokumentacja konserwatorska obrazu Portret Zofii Elżbiety von Kanitz Leonarda Schorera z 1750 r., nr inw. ZKMiRP 945, Toruń 1997. Autorka do kitu barwionego w masie zastosowała werniks retuszerski damarowy z benzyną lakową 1:2.

26 Przykład zastosowania w: D. Lizun, Dokumentacja konserwatorska obrazu Autoportret Kazimierza Kostynowicza, nr inw. ZKMiRP 973, Toruń 1998. Autor do kitu kredowego zastosował izolację z 10\% szelaku w alkoholu etylowym, a następnie retuszerski werniks damarowy - matowy z błyszczącym i benzyną lakową w stosunku 2:1:3.

27 Przykład zastosowania w: E. Grzesiuk, Dokumentacja konserwatorska obrazu Ukrzyżowanie ze Św. Maria Magdalena, nr inw. ZKMiRP 730, Torun 1992/1993. Autorka do kitu z kredą i pigmentami zastosowała równomiernie i cienko rozprowadzoną międzywarstwę z 3\% MC, po czym dwukrotnie zawerniksowała. 
tylko zafalowanie i pojawienie się nierówności płótna, wówczas jego skuteczne prostowanie odbywało się na stole próżniowym z wykorzystaniem podwyższonej temperatury ${ }^{28}$. Jako środek zaradczy stosowano też zakładanie kitu na niewielką powierzchnię i opracowywanie go przed wypełnieniem następnej partii ${ }^{29}$. W przypadku uzupełniania ubytków o znacznej głębokości, gdy grubość wypełnienia jest duża, wprowadzenie wilgoci oprócz deformacji płótna może spowodować pękanie kitu. Dzieje się tak zwłaszcza wtedy, gdy ubytki mają znaczną powierzchnię. W takiej sytuacji kity najczęściej były ścieniane, częściowo usuwane, zakładane ponownie, a obraz prostowany na stole próżniowym, co pozwalało też na lepsze związanie kitów z podłożem i ustabilizowanie całego układu $^{30}$.

\subsection{Charakterystyka modyfikowanego kitu klejowo- -kredowego według Slanskiego}

Receptura kitu pochodzi z dokumentacji konserwatorskiej obrazu na podłożu drewnianym Adoracja Dzieciatka ${ }^{31}$. Jego skład jest następujący:

10\% roztwór kleju króliczego - 1 część objętościowa,

kreda strącana - 3 części wagowe,

kreda bolońska - 1 część wagowa,

terpentyna wenecka - 0,2 części objętościowej.

Modyfikacja w stosunku do receptury podanej przez Slanskiego ${ }^{32}$ jest dosyć poważna, gdyż polega na zmianie charakteru kitu z emulsyjnego na

28 Przykład takiego rozwiązania w: M. Stepińska, Dokumentacja konserwatorska obrazu Tobiasz i Anioł, nr inw. ZKMiRP 834, Toruń 1996, s. 24.

29 Przykład takiego rozwiązania w: D. Chojnicka, Dokumentacja konserwatorska obrazu Zadumany starzec, nr inw. ZKMiRP 556, Toruń 1987. Autorka podaje, że jednorazowo zakładała kit na powierzchnie ok. $25 \mathrm{~cm}^{2}$.

30 Przykład takiego rozwiązania w: A. Kubejko, Dokumentacja konserwatorska obrazu Amorek, nr inw. ZKMiRP 968, Toruń 1999.

31 K. Wantuch, Dokumentacja konserwatorska obrazu Adoracja Dzieciatka Lazzaro Bastianiego, nr inw. ZKMiRP 685, Torun 1994, s. 51.

32 B. Slansky, Technika malarstwa, t. 2: Badanie i konserwowanie obrazów, Warszawa 1965, s. 240. Skład kitu emulsyjnego: 4 części kredy + 1 cześć wody klejowej o stężeniu 1:10 + + 0,5 cześci oleju polimeryzowanego lub zwykłego. 
klejowo-kredowy przez zmniejszenie ilości plastyfikatora i zastąpienie oleju polimeryzowanego terpentyną wenecką. Autorka określiła też precyzyjnie gatunek użytej kredy, co do którego brak jest szczegółowych wskazówek w publikacji źródłowej. Slansky ${ }^{33}$ wymienia kredę bolońską, szampańską i pławioną, jako odpowiednie do sporządzenia kitu do uzupełniania ubytków zaprawy w malarstwie sztalugowym, nie preferując jednoznacznie żadnej z nich. Jedynie przy okazji omawiania problemów związanych z uzupełnianiem ubytków zaprawy na drewnianych rzeźbach polichromowanych wskazuje na kredę bolońską, jako właściwą do przyrządzenia kitu ${ }^{34}$. W charakterystyce tego wypełniacza autor odnotowuje, że z klejem skórnym daje ona bardzo wartościowe i elastyczne podłoża wykorzystywane m.in. w złoceniu na poler ${ }^{35}$. Potwierdza to T. Sadziak ${ }^{36}$, pisząc, że grunty z kreda bolońską zakładane nawet w warstwach o grubości $1 \mathrm{~cm}$ nie pekają. Wypełniacz ten wymaga zastosowania około 20\% roztworu kleju - a więc mocniejszego niż kreda szampańska czy rugijska - i podgrzewania jedynie do $50^{\circ} \mathrm{C}$, aby nie stracić delikatnej struktury. Podkreśla ponadto, że nazwa kreda bolońska, którą błędnie określa się często różne gatunki kredy, w istocie rzeczy oznacza gips pławiony. Jako zalety gruntu z kredą bolońską wymienia także mniejszy skurcz liniowy podczas wysychania, podkłady bielsze od kredowych, odporność na pękanie czy kruszenie powierzchni podczas szlifowania na sucho. Do wad gruntu z kredą bolońską T. Sadziak zalicza małą zdolność krycia i trudniejsze od innych gruntów zakładanie. Ponadto zauważa, że grunty te mają tendencje do wykwitów igieł gipsu na powierzchni warstwy malarskiej, nawet jeśli pośrednią warstwę stanowi grunt kredowy ${ }^{37}$.

Kreda strącana, która wraz z kredą bolońską została użyta przez K. Wantuch do sporządzenia kitu, jest nazywana sztuczną z powodu otrzymywania jej przez stracenie weglanem sodu $\mathrm{z}$ roztworu chlorku wapnia ${ }^{38}$. Od kredy

33 Ibidem, s. 237.

34 Ibidem, s. 312.

35 B. Slansky, Technika malarstwa, t. 1: Materiały do malarstwa i konserwacji, Warszawa 1960, s. 30.

36 T. Sadziak, Klejowe i olejne prace pozłotnicze, „Biblioteka Muzealnictwa i Ochrony Zabytków", seria B, t. 69, Warszawa 1981, s. 40.

37 Ibidem, przypis 107, s. 79.

38 B. Slansky, Technika malarstwa, t. 1: Materiały, s. 30. 
naturalnej różni się tym, że jest czystsza i drobniejsza. Uważa się, że bardziej regularna budowa cząsteczek kredy strącanej powoduje większe ich uszczelnienie („upakowanie”), redukujące absorpcję spoiwa, co może skutkować niecałkowitym sklejeniem masy ${ }^{39}$. Naturalna kreda pozłotnicza - szampańska, rugijska - która ma cząsteczki o różnym i nieregularnym kształcie oraz wielkości, jest chętniej używana i polecana jako wartościowa do sporządzania gruntów i kitów. Jako jej wady wymienia się: kruchość powłoki, trudności obróbki na sucho i pękanie przy pracującym podłożu drewnianym ${ }^{40}$.

Wybór odpowiedniego kitu w przypadku konserwacji obrazu Adoracja Dzieciatka został poprzedzony wstepnymi próbami z kitem emulsyjnym „wiedeńskim” i klejowo-kredowym modyfikowanym. Autorka założyła obie masy w ubytki w dwóch oznaczonych miejscach na obrazie i pozostawiła na okres letnich wakacji w warunkach około 60-80\% wilgotności względnej. W ocenie autorki kit klejowo-kredowy modyfikowany wypadł lepiej w tym porównaniu, dlatego zdecydowała się go zastosować, mimo że jego użycie wiązało się z pewną niedogodnością, jaką jest rozgrzewanie i nakładanie na ciepło $^{41}$.

\section{Badanie właściwości fizykochemicznych}

\subsection{Opis materiałów poddanych testom badawczym}

Pięć gotowych kitów i dwa sporządzone według receptur w postaci świeżych, niezwiązanych preparatów poddano analizie wizualnej, biorąc pod uwage podstawowe właściwości fizyczne. Obserwacje zestawiono w poniższej tabeli.

39 J. Green, J. Seddon, A study of materials for filling losses in easel paintings, and their receptiveness to casting of textures, [w:] ICOM Comittee for Conservation, 6th Triennial Meeting, Ottawa 1981, s. 81/2/12-6.

40 T. Sadziak, op. cit., s. 40.

$41 \quad$ K. Wantuch, op. cit., s. 70. 
Tab. 1. Wyniki wizualnej analizy świeżych, niezwiązanych preparatów

\begin{tabular}{|c|c|c|c|c|}
\hline Rodzaj kitu & Konsystencja & Kolor & $\begin{array}{c}\text { Charakterystyczny } \\
\text { zapach }\end{array}$ & $\begin{array}{l}\text { Opakowanie } \\
\text { firmowe }\end{array}$ \\
\hline 1. Tikkurila & $\begin{array}{l}\text { gesta, zwarta pasta (jak } \\
\text { chałwa) }\end{array}$ & śnieżnobiały & amoniaku & $\begin{array}{c}\text { metalowa } \\
\text { puszka }\end{array}$ \\
\hline 2. Italstucco & $\begin{array}{l}\text { dość rzadka pasta } \\
\text { (jak gęsta śmietana) }\end{array}$ & biały & brak & $\begin{array}{l}\text { plastikowy } \\
\text { pojemnik }\end{array}$ \\
\hline 3. Modostuc & $\begin{array}{l}\text { nieco ciagliwa, gesta pasta } \\
\text { (jak surowe ciasto) }\end{array}$ & $\begin{array}{l}\text { biały o cieplym } \\
\text { odcieniu }\end{array}$ & migdałów & $\begin{array}{l}\text { plastikowy } \\
\text { pojemnik }\end{array}$ \\
\hline 4. BEVA Gesso-P & $\begin{array}{l}\text { gęsta, niezbyt zwarta, } \\
\text { „puszysta” pasta }\end{array}$ & jasny ugier & toluenu & $\begin{array}{l}\text { metalowa } \\
\text { puszka }\end{array}$ \\
\hline 5. BEVA Gesso-V & $\begin{array}{l}\text { gesta, niezbyt zwarta, } \\
\text { „puszysta” pasta } \\
\text { z widoczną granulacją } \\
\text { wypełniacza }\end{array}$ & ciemny ugier & toluenu & $\begin{array}{c}\text { metalowa } \\
\text { puszka }\end{array}$ \\
\hline $\begin{array}{l}\text { 6. Emulsyjny } \\
\text { „wiedeński” }\end{array}$ & $\begin{array}{l}\text { rzadka pasta o znacznej } \\
\text { płynności (jak niezbyt } \\
\text { gęsta śmietana) }\end{array}$ & $\begin{array}{c}\text { biały o ciepłym } \\
\text { odcieniu }\end{array}$ & $\begin{array}{c}\text { olejku } \\
\text { terpentynowego } \\
\text { i terpentyny } \\
\text { weneckiej }\end{array}$ & - \\
\hline $\begin{array}{l}\text { 7. Kredowo-klejowy } \\
\text { modyfikowany }\end{array}$ & $\begin{array}{l}\text { gesta zżelowana, po } \\
\text { ogrzaniu upłynniająca się } \\
\text { (do konsystencji niezbyt } \\
\text { gęstej śmietany) }\end{array}$ & $\begin{array}{c}\text { biały o ciepłym } \\
\text { odcieniu }\end{array}$ & $\begin{array}{l}\text { kleju glutynowego } \\
\text { i terpentyny } \\
\text { weneckiej }\end{array}$ & - \\
\hline
\end{tabular}

\subsection{Badania składu chemicznego gotowych preparatów fabrycznych}

\subsubsection{Badanie składu chemicznego gotowych preparatów fabrycznych metodą termicznej analizy różnicowej ${ }^{42}$}

Termiczna analiza różnicowa (DTA) daje możliwość identyfikacji jakościowej i ilościowej niektórych związków chemicznych. Metoda ta polega na rejestrowaniu zmian zachodzących w badanej próbce pod wpływem wahań temperatury, równomiernych w czasie, oraz na analizie ilościowej ${ }^{43}$.

42 Badania zostały przeprowadzone w Zakładzie Konserwacji Detalu Architektonicznego i Rzeźby przez dr Marię Kęsy-Lewandowską.

43 T. Bąk, J. Ptak, Analiza termiczna, [w:] Metody badawcze stosowane w identyfikacji i diagnostyce dzieł sztuki, Zeszyty Naukowe ASP w Krakowie, Kraków 1980, s. 20-26. 
Materiały wytypowane do badań:

1. Kit Tikkurila.

2. Kit Italstucco.

3. Kit Modostuc.

Przygotowanie próbek do badań:

Próbki poszczególnych kitów w ilości ok. 600 mg każda pozostawiono do związania i wyschnięcia w warunkach powietrzno-suchych (ok. $20^{\circ} \mathrm{C}$, 50\% RH) i w takich samych warunkach poddano sezonowaniu trwającemu trzy tygodnie. Po upływie tego czasu dosuszono je w suszarce próżniowej w temp. $50^{\circ} \mathrm{C}$, po czym je zmielono i kolejno umieszczano w tygielku.

Badania składu chemicznego wykonano metodą termicznej analizy różnicowej (DTA) na Q derywatografie (MOM, Wegry).

Warunki pomiaru:

TG: $200 \mathrm{mg}$, zakres temperatur: $20^{\circ} \mathrm{C}-1000^{\circ} \mathrm{C}$, szybkość grzania: $10^{\circ} \mathrm{C} / \mathrm{min}$,

DTA: $250 \mu \mathrm{V}$,

DTG: $500 \mu \mathrm{V}$,

szybkość przesuwu taśmy: $2,5 \mathrm{~mm} / \mathrm{min}$,

tygiel ceramiczny, atmosfera powietrza.

\subsubsection{Badanie składu chemicznego gotowych preparatów fabrycznych metodą spektroskopii absorpcyjnej w podczerwieni ${ }^{44}$}

Spektroskopia absorpcyjna w podczerwieni (IR), pozwalająca na identyfikację wielu związków chemicznych, polega na poddawaniu badanej substancji promieniowaniu podczerwonemu i obserwacji tego promieniowania ${ }^{45}$. Materiały wytypowane do badań:

Identycznie jak w punkcie 2.2.1.

44 Badania zostały przeprowadzone w Zakładzie Konserwacji Detalu Architektonicznego i Rzeźby przez dr Marię Kęsy-Lewandowską.

45 B. Mitka, Spektrofotometria, [w:] Metody badawcze stosowane, s. 53-57. 
Przygotowanie próbek do badań:

Podobnie jak w punkcie 2.2.1. Po zmieleniu próbek wykonano przezroczyste tabletki w bromku potasu. Związki organiczne ekstrahowano chloroformem.

Badania składu chemicznego wykonano metodą spektroskopii absorpcyjnej w podczerwieni na aparacie SPECORD 75 IR (CARL ZEISS JENA, NRD), metodą pastylki z $\mathrm{KBr}$ w zakresie drgań promieniowania 400-4000 $\mathrm{cm}^{-1}$. Podsumowanie wyników badań (tab. 2) i wnioski:

Tab. 2. Skład chemiczny gotowych preparatów - zestawienie wyników badań metodą termicznej analizy różnicowej oraz metoda spektroskopii absorpcyjnej w podczerwieni

\begin{tabular}{|c|c|c|c|}
\hline $\begin{array}{l}\text { Rodzaj } \\
\text { kitu }\end{array}$ & $\begin{array}{l}\text { Termiczna analiza } \\
\text { różnicowa }\end{array}$ & $\begin{array}{c}\text { Spektroskopia absorpcyjna } \\
\text { w podczerwieni }\end{array}$ & $\begin{array}{l}\text { Jakościowy skład } \\
\text { chemiczny }\end{array}$ \\
\hline 1. Tikkurila & $\begin{array}{l}\text { ok. } 46,76 \% \text { węglanu } \\
\text { wapnia; } \\
\text { ok. } 35,48 \% \text { weglanu } \\
\text { magnezu (?) na podstawie } \\
\text { ubytku masy w zakresie } \\
\text { temp. } 600^{\circ} \mathrm{C}-780^{\circ} \mathrm{C} \\
\text { (interpretacja niepewna, } \\
\text { wymaga potwierdzenia } \\
\text { badaniem metodą dyfrakcji } \\
\text { rentgenowskiej); } \\
8,69 \% \text { substancji } \\
\text { organicznej } \\
\text { (ubytek masy w zakresie } \\
\text { temp. } 120^{\circ} \mathrm{C}-518^{\circ} \mathrm{C} \text {, } \\
\text { któremu towarzyszy efekt } \\
\text { egzotermiczny) }\end{array}$ & $\begin{array}{l}\text { widmo IR dla pastylki z KBr zawiera } \\
\text { pasma charakterystyczne dla weglanów; } \\
\text { widmo IR błonki uzyskanej z ekstraktu } \\
\text { chloroformowego zawiera szereg pasm } \\
\text { absorpcji charakterystycznych dla } \\
\text { polimerów akrylowych (pasma przy } \\
826,1163,1250 \text { i } 1730 \mathrm{~cm}^{-1} \text { ) }\end{array}$ & $\begin{array}{l}\text { - weglan wapnia; } \\
\text { - prawdopodobnie } \\
\text { weglan magnezu; } \\
\text { - składnik } \\
\text { pochodzenia } \\
\text { organicznego - } \\
\text { przypuszczalnie } \\
\text { z grupy polimerów } \\
\text { akrylowych }\end{array}$ \\
\hline 2. Italstucco & $\begin{array}{l}\text { 77,24\% węglanu wapnia; } \\
\text { 19,36\% gipsu; } \\
\text { 3,14\% substancji } \\
\text { organicznej } \\
\text { (ubytek masy w zakresie } \\
\text { temp. } 180^{\circ} \mathrm{C}-600^{\circ} \mathrm{C} \text {, } \\
\text { któremu towarzyszy efekt } \\
\text { egzotermiczny) }\end{array}$ & $\begin{array}{l}\text { widmo IR wykonane metodą pastylki } \\
\text { z KBr zawiera pasma charakterystyczne } \\
\text { dla gipsu i weglanów; } \\
\text { widmo błonki uzyskanej z ekstraktu } \\
\text { chloroformowego zawiera pasma } \\
\text { absorpcji wskazujące z dużym } \\
\text { prawdopodobieństwem na polioctan } \\
\text { winylu (pasma przy } 714,943,1235 \text {, } \\
1370 \text { i } 1739 \mathrm{~cm}^{-1} \text { ) }\end{array}$ & $\begin{array}{l}\text { - gips; } \\
\text { - węglan wapnia; } \\
\text { - prawdopodobnie } \\
\text { polioctan winylu }\end{array}$ \\
\hline
\end{tabular}


Tab. 2. Skład chemiczny gotowych preparatów (ciagg dalszy)

\begin{tabular}{|c|c|c|c|}
\hline $\begin{array}{l}\text { Rodzaj } \\
\text { kitu }\end{array}$ & $\begin{array}{l}\text { Termiczna analiza } \\
\text { różnicowa }\end{array}$ & $\begin{array}{c}\text { Spektroskopia absorpcyjna } \\
\text { w podczerwieni }\end{array}$ & $\begin{array}{l}\text { Jakościowy skład } \\
\text { chemiczny }\end{array}$ \\
\hline 3. Modostuc & $\begin{array}{l}76,41 \% \text { weglanu wapnia; } \\
6,38 \% \text { substancji } \\
\text { organicznej } \\
\text { (ubytek masy do } 600^{\circ} \mathrm{C} \text {, } \\
\text { któremu towarzyszy efekt } \\
\text { egzotermiczny) }\end{array}$ & $\begin{array}{l}\text { widmo IR otrzymane metodą pastylki } \\
\text { w KBr zawiera pasma absorpcji } \\
\text { charakterystyczne dla węglanów oraz } \\
\text { siarczanów; } \\
\text { próba na zabarwienie płomienia } \\
\text { wskazuje na prawdopodobieństwo } \\
\text { obecności związków baru - wobec } \\
\text { tego nie wyklucza się występowania } \\
\text { siarczanu baru; } \\
\text { widmo błonki otrzymanej z ekstraktu } \\
\text { chloroformowego kitu zawiera pasma } \\
\text { absorpcji charakterystyczne dla } \\
\text { polioctanu winylu (pasma przy } 714 \text {, } \\
943,1370 \text { i } 1739 \mathrm{~cm}^{-1} \text { ) }\end{array}$ & $\begin{array}{l}\text { - węglan wapnia; } \\
\text { - prawdopodobnie } \\
\text { siarczan baru; } \\
\text { - prawdopodobnie } \\
\text { polioctan winylu }\end{array}$ \\
\hline
\end{tabular}

Wyniki uzyskane z obu powyższych badań potwierdzają skład jakościowy (podstawowe składniki) kitu Modostuc podany przez producenta. Badania nie pozwoliły na zidentyfikowanie dodatków, które zostały użyte w znikomych ilościach. Z analogiczną sytuacją należy się liczyć w przypadku dwu pozostałych, badanych tymi metodami kitów (nr 1 i nr 2).

\subsection{Ocena właściwości związanych z aplikacją i wiązaniem badanych kitów}

W trakcie przygotowywania próbek do badań kity przetestowano pod kątem łatwości użycia, możliwości zakładania za pomocą różnych narzędzi w ubytki zaprawy, czasu wysychania, a także czasu, po którym możliwe jest opracowywanie powierzchni. Zwrócono uwagę na zachowanie się materiałów podczas nanoszenia ich na płótno, na możliwość (ewentualnie konieczność) rozcieńczania lub zagęszczania, na wygląd i charakter powierzchni po wyschnięciu uzupełnienia.

Omówienie wyników badań (zob. tab. 3):

Wszystkie badane kity występują w postaci past różniących się nieco między sobą konsystencją - od gęstej i zwartej do płynnej i rozlewnej. Kity od nr 1 do nr 6 można stosować bezpośrednio z pojemnika, w którym są 
przechowywane, bez dodatkowego przygotowywania. Pewną niedogodnością przy stosowaniu kitu nr 7 - klejowo-kredowego - jest konieczność rozgrzania i trzymania w czasie pracy na łaźni wodnej, co pozwala na upłynnienie zżelowanego kleju. W przypadku nanoszenia kitów nr 4 i nr 5, szczególnie rozprowadzania ich w rozległych ubytkach, trudności może przysparzać „rozrywanie się” mas spowodowane ich nieznaczną lepkością. Jednakże odpowiedni sposób operowania narzędziem, polegający na prowadzeniu go w jednym kierunku z niezbyt mocnym dociskaniem, powoduje wygładzenie powierzchni i umożliwia uzyskanie zwartego, jednorodnego wypełnienia.

Konsystencja kitów determinuje dobór narzędzia, za pomocą którego wypełnianie ubytków jest najłatwiejsze i najbardziej efektywne. Wszystkie kity można łatwo aplikować za pomocą elastycznych szpachelek malarskich, skalpeli i łopatek dentystycznych, co jest najwygodniejsze w przypadku ubytków niewielkich i o średniej wielkości. Taki sposób uzupełniania ubytków wiąże się z możliwością zabrudzenia substancji oryginalnej w bezpośrednim sąsiedztwie, którą w takim przypadku należy przed przystapieniem do wypełniania ubytków zabezpieczyć werniksem ochronnym. W przypadku ubytków, które wymagają uzupełniania za pomocą pędzla (np. duże powierzchnie, nieznaczne grubości warstw malarskich), możliwość taką daje kit nr 6 , jako najbardziej płynny, a po rozcieńczeniu wodą również kity nr 1, nr 2, nr 3 i nr 7. Jednakże w przypadku rozcieńczania kitów należy się liczyć z możliwością zwiększenia ich skurczu podczas wysychania, a także nieznacznego obniżenia stężenia spoiw, sklejających wypełniacze w kitach. Trzeba też pamiętać, że zarówno rozcieńczanie rozpuszczalnikami, jak i zagęszczanie za pomoca wypełniaczy czy też znaczny dodatek pigmentów barwiących mase może w pewnym stopniu wpłynąć na zmianę właściwości kitu w stosunku do podstawowej, poddanej niniejszym badaniom postaci. Wobec tego po dokonaniu jakichkolwiek modyfikacji wskazane jest wykonanie podstawowych prób na ścieralność, elastyczność i twardość kitu, zanim zastosuje się go w obrazie.

Czas wysychania określano na próbkach kitów o grubości 0,5 mm, które naniesiono za pomocą szablonu na płótno lniane. Warunki, w których przeprowadzono badania i obserwacje, wynosiły: temp. $23^{\circ} \mathrm{C}$ i RH ok. $65 \%$. Czas wysychania dla poszczególnych rodzajów kitów jest nieco zróżnicowany. Można wyodrębnić dwie fazy tego procesu: pierwszą, w której następuje 
Tab. 3. Właściwości fizyczne kitów związane z aplikacją materiałów na płótno

\begin{tabular}{|c|c|c|c|c|}
\hline $\begin{array}{l}\text { Rodzaj } \\
\text { kitu }\end{array}$ & $\begin{array}{l}\text { Sposób } \\
\text { aplikacji }\end{array}$ & $\begin{array}{l}\text { Rozcieńczanie (I), } \\
\text { zagęszczanie (II), } \\
\text { barwienie (III) }\end{array}$ & $\begin{array}{l}\text { Czas wysychania } \\
\text { kitu o gr. } 0,5 \mathrm{~mm} \\
\text { w temp. } 23^{\circ} \mathrm{C} \\
\text { i RH } 65 \%[\mathrm{~min}]\end{array}$ & $\begin{array}{l}\text { Wygląd powierzchni } \\
\text { po wyschnięciu }\end{array}$ \\
\hline 1. Tikkurila & $\begin{array}{l}\text { szpachelka, } \\
\text { skalpel, łopatka, } \\
\text { po rozcieńczeniu } \\
\text { pedzel }\end{array}$ & $\begin{array}{l}\text { (I) może być konieczne } \\
\text { - woda } \\
\text { (II) zbędne } \\
\text { (III) suchy pigment, } \\
\text { farba akrylowa }\end{array}$ & $\begin{array}{l}\text { I faza } \\
\text { ok. } 35-45 \\
\text { II faza } \\
\text { ok. } 160\end{array}$ & $\begin{array}{l}\text { gładka, biała, matowa, } \\
\text { mogą wystepować } \\
\text { maleńkie dziurki } \\
\text { po pęcherzykach } \\
\text { powietrza }\end{array}$ \\
\hline 2. Italstucco & $\begin{array}{l}\text { szpachelka, } \\
\text { skalpel, łopatka, } \\
\text { po rozcieńczeniu } \\
\text { pedzel }\end{array}$ & $\begin{array}{l}\text { (I) woda } \\
\text { (II) kreda } \mathrm{CaCO}_{3} \\
\text { (III) suchy pigment, } \\
\text { farba akrylowa }\end{array}$ & $\begin{array}{l}\text { If faza } \\
\text { ok. } 30 \\
\text { II faza } \\
\text { ok. 120-150 }\end{array}$ & $\begin{array}{l}\text { biała, gładka, równa, } \\
\text { matowa }\end{array}$ \\
\hline 3. Modostuc & $\begin{array}{l}\text { szpachelka, } \\
\text { skalpel, łopatka, } \\
\text { po rozcieńczeniu } \\
\text { pędzel }\end{array}$ & $\begin{array}{l}\text { (I) woda } \\
\text { (II) zbędne } \\
\text { (III) suchy pigment, } \\
\text { farba akrylowa }\end{array}$ & $\begin{array}{l}\text { If faza } \\
\text { ok. } 30 \\
\text { II faza } \\
\text { ok. } 120-150\end{array}$ & $\begin{array}{l}\text { biała o ciepłym } \\
\text { odcieniu, gładka, } \\
\text { równa, matowa }\end{array}$ \\
\hline $\begin{array}{l}\text { 4. BEVA } \\
\text { Gesso-P }\end{array}$ & $\begin{array}{l}\text { szpachelka, } \\
\text { skalpel, łopatka }\end{array}$ & $\begin{array}{l}\text { (I) rozpuszczalniki } \\
\text { alifatyczne - benzyna } \\
\text { lakowa - i aromatyczne } \\
\text { - ksylen, toluen } \\
\text { (II) zbędne } \\
\text { (III) suchy pigment }\end{array}$ & $\begin{array}{l}\text { I faza } \\
\text { ok. 15-20 } \\
\text { II faza } \\
\text { ok. 45-50 }\end{array}$ & $\begin{array}{l}\text { jasnougrowa, gładka, } \\
\text { równa, matowa }\end{array}$ \\
\hline $\begin{array}{l}\text { 5. BEVA } \\
\text { Gesso- } V\end{array}$ & $\begin{array}{l}\text { szpachelka, } \\
\text { skalpel, łopatka }\end{array}$ & $\begin{array}{l}\text { (I) rozpuszczalniki } \\
\text { alifatyczne - benzyna } \\
\text { lakowa - i aromatyczne } \\
\text { - ksylen, toluen } \\
\text { (II) zbędne } \\
\text { (III) suchy pigment }\end{array}$ & $\begin{array}{l}\text { I faza } \\
\text { ok. 15-20 } \\
\text { II faza } \\
\text { ok. } 45-50\end{array}$ & $\begin{array}{l}\text { ugrowa, gładka lub } \\
\text { porowata z widoczną } \\
\text { granulacją wypełniacza, } \\
\text { matowa }\end{array}$ \\
\hline $\begin{array}{l}\text { 6. Emulsyjny } \\
\text { „wiedeński” }\end{array}$ & $\begin{array}{l}\text { szpachelka, } \\
\text { skalpel, łopatka, } \\
\text { pecdzel }\end{array}$ & $\begin{array}{l}\text { (I) woda } \\
\text { (II) kreda } \mathrm{CaCO}_{3} \\
\text { (III) suchy pigment }\end{array}$ & $\begin{array}{l}\text { If faza } \\
\text { ok. 50-60 } \\
\text { II faza } \\
\text { ok. 150-180 }\end{array}$ & $\begin{array}{l}\text { biała o ciepłym } \\
\text { odcieniu, gładka } \\
\text { z nieznacznie } \\
\text { odwzorowaną } \\
\text { strukturą płótna }\end{array}$ \\
\hline $\begin{array}{l}\text { 7. Kredowo- } \\
\text {-klejowy } \\
\text { modyfikowany }\end{array}$ & $\begin{array}{l}\text { szpachelka, } \\
\text { skalpel, łopatka, } \\
\text { po rozcieńczeniu } \\
\text { pędzel }\end{array}$ & $\begin{array}{l}\text { (I) woda, słaba woda } \\
\text { klejowa } \\
\text { (II) zbędne } \\
\text { (III) suchy pigment, } \\
\text { wodorozcieńczalne } \\
\text { farby }\end{array}$ & $\begin{array}{l}\text { I faza } \\
\text { ok. 15-20 } \\
\text { II faza } \\
\text { ok. } 150\end{array}$ & $\begin{array}{l}\text { biała o ciepłym } \\
\text { odcieniu, gładka lub } \\
\text { nieco porowata, równa, } \\
\text { matowa }\end{array}$ \\
\hline
\end{tabular}


odparowanie części najbardziej lotnych i zestalenie się, stwardnienie masy kitu w zewnętrznej warstwie (dotknięcie palcem nie powoduje przyklejania ani odwzorowania odcisku na powierzchni, jednak wyczuwa się, że kit jest nadal mokry i chłodny; powierzchnia nie wykazuje w tej fazie odporności na próby stawiania na niej skalpela - pod własnym ciężarem narzędzia jego czubek zagłębia się, pozostawiając niewielkie wgłębienie). Podczas drugiej fazy wysychania następuje całkowite odparowanie wody i rozpuszczalników, po którym wypełnienia stają się zupełnie suche, uzyskują odporność na niezbyt silne (bierne) urazy mechaniczne, dają się szlifować i ścinać. Stan taki wszystkie kity osiagają po kilku godzinach.

Wygląd powierzchni po wyschnięciu w dużej mierze zależy od narzędzia, sposobu nanoszenia i grubości kitu. Generalnie wszystkie badane kity dają możliwość uzyskania gładkiej, matowej, równej powierzchni. W przypadku rozcieńczania i nanoszenia kitów za pomocą pędzla możliwe jest odwzorowanie na powierzchni nierówności płótna, a także duktu pędzla (co może być wykorzystane do uzyskania na powierzchni kitu faktury zgodnej z otaczającą warstwą malarską). Kolory wyschniętych kitów w zasadzie odpowiadają kolorom mokrych preparatów. Wyjątkiem są tutaj kity BEVA Gesso-P i BEVA Gesso-V, które znacznie jaśnieją po wyschnięciu - pierwszy z nich uzyskuje kolor rozbielonego ugru, drugi jasnego ugru.

\subsection{Badania przydatności materiałów do odciskania faktur z użyciem form z tworzyw sztucznych}

Odciskanie faktur na powierzchniach kitów wykonano z użyciem form negatywowych $^{46}$ z Aralditu CY 221 i kauczuku silikonowego Polastosil M-69. Wybrano cztery różne formy, po dwie dla każdego rodzaju tworzywa: dla Aralditu - pierwszy model o wymiarach $25 \mathrm{~mm} \times 70 \mathrm{~mm} \times 10 \mathrm{~mm}$, z fakturą płótna (odlew zdjęty z odwrocia obrazu), oraz drugi model o wymiarach

46 Wykorzystane w badaniach formy zostały wykonane przez D. Nowacka w ramach pracy magisterskiej dotyczacej problematyki opracowywania faktur w kitach i załączone przez autorkę do egzemplarza przechowywanego w bibliotece Zakładu Konserwacji Malarstwa i Rzeźby Polichromowanej UMK w Toruniu. Sposób przygotowania form został opisany szczegółowo w: D. Nowacka, op. cit., s. 80-83. 
$25 \mathrm{~mm} \times 50 \mathrm{~mm} \times 10 \mathrm{~mm}$, z odlewem faktury utworzonej przez grubo naniesioną warstwę farby olejnej. W przypadku kauczuku silikonowego modele powtarzały dwa rodzaje faktury utworzonej przez pedzel: pierwszy model o wymiarach $35 \mathrm{~mm} \times 55 \mathrm{~mm} \times 10 \mathrm{~mm}$ odwzorowujący dukt ukośnie prowadzonego szczecinowego pedzla, drugi o wymiarach $25 \mathrm{~mm} \times 65 \mathrm{~mm} \times$ $\times 25 \mathrm{~mm}$ o fakturze grubej, modelowanej pędzlem warstwy farby olejnej (il. 1-5).

Przygotowanie próbek do badań:

Zdekatyzowane płótno lniane, wyprasowane i przeklejone 2\% metylocelulozą, naciągnięto na sztywną płyte pilśniową i przymocowano do niej za pomocą zszywek tapicerskich wzdłuż krawędzi. Powierzchnię płótna podzielono w pionie na dwie, a w poziomie na siedem równych cześci, przyporządkowując każdemu kitowi jedną z nich. Próbki nanoszone na lewą część przeznaczono do badania z użyciem form z Aralditu, a na prawą część - form z kauczuku silikonowego. Poszczególne próbki nakładano kolejno za pomocą szablonu z wyciętym otworem o wymiarach $35 \mathrm{~mm} \times 24 \mathrm{~mm}$. Szablon mocowano taśmą do podłoża i aplikowano masę za pomocą szpachli, wyrównywano powierzchnię kitu, po czym szablon usuwano. Dla każdej formy przeznaczono po dwa powtórzenia, co dla każdego kitu dało łącznie osiem próbek. Próbki pozostawiano do wstępnego wyschnięcia, którego czas odpowiadał w przybliżeniu I fazie odnotowanej w punkcie 2.3. Nastepnie natartą talkiem lub olejem lnianym formę przykładano do powierzchni kitu i przyciskano palcem, a po chwili model zdejmowano z próbki. W przypadku zniszczenia lub uszkodzenia próbki na skutek cześciowego lub całkowitego oderwania od podłoża wraz z formą - całą procedure powtarzano od początku, modyfikując ten element metodyki, który uniemożliwił za pierwszym razem odłączenie dwóch materiałów (czas wysychania próbki, rodzaj środka antyadhezyjnego, ewentualne podgrzanie formy). Po wyschnięciu wszystkich próbek z odciśniętą fakturą płótno nabito na krosna malarskie. Wyniki badań:

Uzyskanie faktury na powierzchni wypełnienia z użyciem form z tworzyw z Aralditu i kauczuku silikonowego jest możliwe w przypadku wszystkich badanych materiałów, jednakże różny jest stopień dokładności i wierności odwzorowania faktury (il. 1-4). Wyniki badań zestawiono w poniższej tabeli. 
Tab. 4. Odwzorowanie faktury na powierzchni kitów z zastosowaniem form negatywowych

\begin{tabular}{|l|c|c|c|c|}
\hline \multirow{2}{*}{ Rodzaj kitu } & \multicolumn{4}{|c|}{ Odwzorowanie faktury za pomocą form } \\
\cline { 2 - 5 } & Araldite CY 221 & \multicolumn{2}{c|}{ kauczuk silikonowy Polastosil M-69 } \\
\cline { 2 - 5 } & splot płótna & $\begin{array}{c}\text { modelunek } \\
\text { w warstwie farby }\end{array}$ & dukt pędzla & $\begin{array}{c}\text { modelunek } \\
\text { w warstwie farby }\end{array}$ \\
\hline 1. Tikkurila & +++ & ++- & +++ & ++- \\
\hline 2. Italstucco & +++ & +++ & +++ & ++- \\
\hline 3. Modostuc & +++ & +++ & +++ & ++- \\
\hline 4. BEVA Gesso-P & ++- & ++- & +-- & +-- \\
\hline 5. BEVA Gesso-V & +-- & ++- & +-- & +-- \\
\hline 6. „Wiedeński” & ++- & +-- & ++- & +-- \\
\hline 7. Klejowo-kredowy & +-- & +-- & ++- & ++- \\
\hline
\end{tabular}

Objaśnienia:

+++ bardzo dobre i wierne odwzorowanie faktury,

++- dobre, dość dokładne odwzorowanie faktury,

+ - - słabe, częściowe odwzorowanie faktury.

Omówienie wyników badań i wnioski:

Z przeprowadzonych badań i powyższego zestawienia wynika, że faktury odwzorowane na powierzchni badanych materiałów nie w każdym przypadku są zadowalające. Efekt jest uzależniony zarówno od właściwości samego kitu, jak i od rodzaju faktury, która ma być na nim uzyskana. Generalnie najlepszy rezultat jest osiaggany w przypadku niezbyt głębokich, ale wyrazistych reliefów, takich jak splot płótna i dukt pędzla szczecinowego. Najwięcej możliwości dają kity nr 2, nr 3, nr 1, które okazały się najbardziej plastyczne i podatne na modelowanie. Wszystkie rodzaje faktur - od subtelnych, reliefowych do bardziej rozbudowanych, impastowych - są możliwe do łatwego odciśnięcia w podsychających kitach. Kity te odwzorowują i zachowuja nadane im ukształtowanie powierzchni, przy dobrym odizolowaniu formy antyadhezyjnym środkiem (w tym przypadku talkiem) nie przywierają do niej i podczas oddzielania obu materiałów zachowują dobrą przyczepność do płótna. Sam moment odciskania musi być jednak dobrze dobrany, gdyż zbyt świeże materiały mimo izolacji mogą przykleić się do formy - zwłaszcza jeśli jej powierzchnia jest bardziej „rozrzeźbiona”. 
Kit nr 6 najlepiej odwzorowuje stosunkowo płytkie, ale jednocześnie subtelne reliefy - splot płótna, dukt pędzla. Trudne jest uzyskanie faktury rozbudowanego modelunku warstwy malarskiej, mimo że kit bardzo dobrze odwzorowuje kształt nadany przez formę. Kit wysycha, tworząc najpierw powierzchniową warstewke, będącą w pewnym momencie zdolną do przyjęcia kształtu formy, podczas gdy pod powierzchnią kit jest nadal świeży i stosunkowo płynny. Po usunięciu formy następuje powolne „rozpływanie” się nadanej faktury, co powoduje utratę wyrazistości odcisku i jej spłaszczenie. Pomaga tu nieco pozostawienie formy na wypełnieniu aż do całkowitego wyschnięcia, jednak nie pozwala to na sprawdzenie efektu i ewentualne skorygowanie odcisku, póki nie stanie się on nieplastyczny. Z kolei opóźnienie momentu odciskania do chwili, gdy kit wyschnie w całej masie, powoduje, że staje się on twardy i traci zdolność odwzorowania faktury.

Kit nr 7 wysycha od razu w całej masie, co sprawia, że czas odpowiedni do wykonania odcisku jest dość krótki. Wilgoć obecna w kicie powoduje nawilżenie talku użytego jako środek antyadhezyjny i przywieranie kitu do formy, jeśli przyciska się ją do zbyt świeżego materiału. Skutkuje to odrywaniem się całej próbki od płótna. Nieco lepiej w roli środka antyadhezyjnego spisuje się tu olej lniany. Najlepiej odwzorowane są w tym kicie delikatne, niezbyt głębokie faktury - dukt pędzla, splot płótna.

Kity nr 4 i nr 5 muszą być traktowane nieco odmiennie. Świeże, niezwiązane materiały wykazują stosunkowo niską kohezję i jeszcze niższą adhezję (zwłaszcza kit nr 5). Nawet po powierzchniowym ich wyschnięciu możliwe jest ich oddzielenie się od płótna podczas zdejmowania formy. $Z$ tego powodu odciskanie faktury można rozpocząć po całkowitym wyschnięciu kitów, ale jeszcze przed zupełnym stwardnieniem. Formy muszą być podgrzane do temperatury ok. $50-60^{\circ} \mathrm{C}$ i mocno przyciskane do powierzchni kitów. Dokładniejsze odwzorowanie faktury daje kit nr 4, zawierający drobniejszy wypełniacz. Subtelne ślady duktu pędzla bardzo słabo i niewyraźnie odciskaja się na kicie nr 5 , a bardziej rozbudowana fakturalnie powierzchnia malarska jest odwzorowywana tylko częściowo, bez ostrych szczegółów. Możliwe, że zastosowanie cieńszych form, które pozwoliłyby na podgrzewanie kauterem na wypełnieniu, przyniosłoby lepsze rezultaty.

Analiza przebiegu badań wszystkich materiałów zdaje się dowodzić, że użycie cieńszych, bardziej elastycznych form w znacznym stopniu ułatwiłoby 
odciskanie faktury. Formy pozwalające na wyginanie pod dowolnym kątem umożliwiłyby stopniowe odchylanie od powierzchni opracowywanej i takie zdejmowanie z wypełnienia, które nie powodowałoby zassania kitu i oderwania go od podłoża, co dzieje się podczas podrywania równocześnie całej powierzchni formy (przypomina to stawianie stempli). Możliwe jest, że tworzywa utraciły część swej początkowej elastyczności i stały się dosyć sztywne. Dotyczy to zwłaszcza form z A raldite CY 221, z których jedna nawet popekała. Należy jednak nadmienić, że w momencie przeprowadzania opisywanych badań liczyły one już trzynaście lat - a w czasie, gdy je wykonano, zostały ocenione przez D. Nowacką jako bardzo elastyczne.

\subsection{Badania zmian objętości materiałów (skurczu)}

\subsubsection{Badanie zmian objętości kitów podczas wysychania}

Przygotowanie próbek do badań:

Płótno lniane zdekatyzowane, wyprasowane i przeklejone 2\% metyloceluloza, naciągnięto na sztywną płytę pilśniową o wymiarach $58 \mathrm{~cm} \times$ $\times 50 \mathrm{~cm} \times 0,4 \mathrm{~cm}$ i przymocowano do niej za pomocą zszywek tapicerskich wzdłuż krawędzi. Na powierzchni płótna wyznaczono poziomymi i pionowymi liniami siatkę, pozwalającą na naniesienie próbek kitów w określonym porządku. Każdemu rodzajowi kitu przyporządkowano siedem prostokątów o wymiarach $80 \mathrm{~mm} \times 60 \mathrm{~mm}$, z których każdy stanowił obszar pojedynczej próbki. Poszczególne próbki nakładano za pomocą szablonów, w których wycięto otwory o wymiarach $50 \mathrm{~mm} \times 20 \mathrm{~mm}$. Wykorzystano blachę nierdzewną o grubościach $[\mathrm{mm}]: 3,0 ; 2,0 ; 1,5 ; 1,0 ; 0,8 ; 0,5 ; 0,2$. Nanoszenie próbek z każdego rodzaju kitu rozpoczynano od szablonu o największej grubości; mocowano szablon do podłoża za pomocą taśmy i aplikowano mase jednorazowo w żądanej grubości szpachlą. Próbkę wraz z szablonem pozostawiano do wyschnięcia i wówczas usuwano. W identyczny sposób postępowano, używając szablonów o mniejszych grubościach.

Wyniki badań:

Po sporządzeniu wszystkich próbek przystąpiono do wizualnej oceny, biorąc pod uwagę zmiany objętości spowodowane skurczem kitów w trakcie wysychania, a także wystąpienie spękań na powierzchni lub w masie kitu. 
Omówienie wyników badań i wnioski:

Największym zmianom objętościowym kitów towarzyszą na ogół znaczne, głębokie spękania, przebiegające w wielu kierunkach. Dotyczy to kitów nr 1, nr 2 i nr 3 (il. 6). Skurcz próbek, na których w trakcie wysychania zarysowały sie jedynie drobne powierzchowne spekania, jest mniejszy lub nieznaczny (kit nr 6 oraz mniejsze grubości kitu nr 3). Kity, które kurczą się minimalnie lub wcale, $\mathrm{w}$ trakcie wysychania nie pekają nawet $\mathrm{w}$ grubszych warstwach (kity nr 4, nr 5 i nr 7) (il. 7). Wszystkie kity zakładane w cieńszych warstwach zachowuja po wyschnięciu pierwotne wymiary. Jednak w miarę zwiększania grubości uzyskanej jednorazowo - odchylenia od nich stają się coraz większe i wyraźniejsze. Także różnice między poszczególnymi rodzajami kitów są wówczas znaczne, co obrazuje poniższa tabela.

Tab. 5. Zestawienie wyników badań zmian objętości kitów aplikowanych w różnych grubościach

\begin{tabular}{|l|c|c|c|}
\hline \multirow{2}{*}{ Rodzaj kitu } & Skurcz & Występowanie spękań & Brak spękań \\
\cline { 2 - 4 } & \multicolumn{2}{|c|}{ grubość wypełnienia [mm] } \\
\hline 1. Tikkurila & $\begin{array}{c}3,0-1,5 \text { duży } \\
1,0-0,5 \text { niewielki } \\
\text { poniżej } 0,5 \text { nieznaczny }\end{array}$ & od 1,5 & do 1,0 \\
\hline 2. Italstucco & $\begin{array}{c}3,0-2,0 \text { duży } \\
1,5-0,8 \text { niewielki } \\
\text { poniżej } 0,8 \text { nieznaczny }\end{array}$ & od 2,0 & do 1,5 \\
\hline 3. Modostuc & $\begin{array}{c}3,0-1,5 \text { duży } \\
1,0-0,8 \text { niewielki } \\
\text { poniżej } 0,8 \text { nieznaczny }\end{array}$ & od 0,8 & do 0,5 \\
\hline 4. BEVA Gesso-P & $\begin{array}{c}3,0-2,0 \text { nieznaczny } \\
\text { poniżej 2,0 nikły lub nieobecny }\end{array}$ & - & wszystkie \\
\hline 5. BEVA Gesso-V & $\begin{array}{c}3,0-2,0 \text { nieznaczny } \\
\text { poniżej 2,0 nikły lub nieobecny }\end{array}$ & - & wszystkie \\
\hline 6. „Wiedeński” & $\begin{array}{c}\text { we wszystkich grubościach } \\
\text { nieznaczny }\end{array}$ & od 0,2 & wszystkie \\
\hline 7. Klejowo-kredowy & $\begin{array}{c}\text { we wszystkich grubościach nikły } \\
\text { lub nieobecny }\end{array}$ & - & - \\
\hline
\end{tabular}

$\mathrm{Na}$ podstawie przeprowadzonych badań najwyżej należy ocenić kity nr 4, nr 5 (BEVA Gesso-P i BEVA Gesso-V) i nr 7 (klejowo-kredowy modyfikowany), które najlepiej spełniają warunek nieulegania zmianom objętości 
w trakcie wysychania. Dają one możliwość jednorazowego uzupełniania nawet głębokich ubytków, gdyż kurczą się tylko w minimalnym stopniu lub wcale, a przy tym zupełnie nie pekkają przy wysychaniu. Dobrą ocenę można również wystawić kitowi nr 6 (emulsyjnemu „wiedeńskiemu” ), który wykazuje także niewielki skurcz we wszystkich zadanych grubościach. Jego mankamentem jest występowanie niewielkich powierzchniowych spękań, które łatwo usuną́ przy szlifowaniu i opracowywaniu faktury wypełnienia. Prawdopodobnie udałoby się uniknąć powstawania spękań, zakładając wypełnienia w atmosferze o wyższej wilgotności powietrza (badania przeprowadzano wczesną zimą, gdy wilgotność powietrza w pomieszczeniu wynosiła ok. 25-30\%). Kity nr 1 (Tikkurila), nr 2 (Italstucco) i nr 3 (Modostuc) nie moga być stosowane $\mathrm{w}$ grubszych warstwach, zarówno ze względu na znaczny skurcz, któremu podlegaja, jak i głębokie oraz rozległe spękania. W przypadku używania ich do głębokich wypełnień konieczne jest uzupełnianie w kilku cieńszych warstwach.

\subsection{Oznaczanie kwasowości badanych materiałów}

Pomiaru kwasowości kitów dokonano metodą elektrometryczną za pomocą pH-metru typu N 512 Lic Polymetron MERA-ELMAT. Wzorcem przy oznaczaniu $\mathrm{pH}$ przesączy było $\mathrm{pH}$ buforu, które wynosiło 6 . Badaniom poddano kity oznaczone numerami od 1 do 7 .

\subsubsection{Pomiar $\mathrm{pH}$ materiałów przed związaniem}

Przygotowanie próbek do badań:

W kolbach miarowych naważono po $0,50 \mathrm{~g}$ świeżych, niezwiązanych preparatów. Każdą próbkę zalano wodą destylowaną w ilości $2,5 \mathrm{~cm}^{3}$ i umieszczono w wytrząsarce na 1 godzinę, po czym próbki pozostawiono do sedymentacji. Po upływie trzech dni do każdej kolby dolano po $5 \mathrm{~cm}^{3}$ wody destylowanej ( $\mathrm{pH}$ 7), delikatnie wymieszano i odstawiono na 1 godzinę, po czym zawartość sączono do zlewki. Dla każdego przesączu pomiar pH wykonywano trzykrotnie.

Wyniki badań: 
Pomiędzy poszczególnymi rodzajami kitów występują niewielkie różnice wartości pH, które oscylują pomiędzy 6,9 a 8,5, z tym że najniższą wartość wykazał tylko jeden kit (nr 7), a pozostałe powyżej 7,5-7,7 (nr 2, nr 4, nr 6). Trzy kity wykazały pH o wartościach od 8,1 do 8,5 (nr 3, nr 1, nr 5).

\subsubsection{Pomiar pH materiałów po związaniu}

Przygotowanie próbek do badań:

W kolbach miarowych naważono po 0,50 g związanych kitów, które sezonowano w warunkach powietrzno-suchych przez 4 tygodnie. Dalszy ciag metodyki przygotowania kitów do badania identyczny jak w punkcie 2.6.1. Wyniki badań:

Najniższe wartości pH ponownie wykazał kit $\mathrm{nr} 7(\mathrm{pH} 7,1)$, nieco wyższe kity nr 4 i nr 6 ( $\mathrm{pH} 7,7$ ) oraz nr 3, nr 1 i nr 2 (pH 7,9-8,0). Najwyższą wartość pH odnotowano powtórnie w przypadku kitu nr 5 (pH 8,7).

Omówienie wyników badań i wnioski:

Tab. 6. Zestawienie wyników badań kwasowości kitów przed związaniem oraz po wyschnięciu i sezonowaniu

\begin{tabular}{|l|c|c|}
\hline \multirow{2}{*}{ Rodzaj kitu } & \multicolumn{2}{|c|}{$\mathrm{pH}$ - średnia z trzech pomiarów } \\
\cline { 2 - 3 } & świeże preparaty & wyschnięte kity \\
\hline 1. Tikkurila & 8,2 & 8,0 \\
\hline 2. Italstucco & 7,5 & 8,0 \\
\hline 3. Modostuc & 8,1 & 7,9 \\
\hline 4. BEVA Gesso-P & 7,7 & 7,7 \\
\hline 5. BEVA Gesso-V & 8,5 & 8,7 \\
\hline 6. „Wiedeński” & 7,8 & 7,7 \\
\hline 7. Klejowo-kredowy & 6,9 & 7,1 \\
\hline
\end{tabular}

Wszystkie przebadane kity wykazuja $\mathrm{pH}$ mieszczące się w wąskim zakresie wynoszącym od 6,9 do 8,7. Dotyczy to zarówno materiałów z pierwszej grupy (świeżych), jak i drugiej (związanych). Wartości te wskazują, że kity charakteryzują się odczynem słabo zasadowym (większość) lub obojętnym (jeden kit). Z zestawienia przedstawionego w tabeli 6 wynika, że różnice pH między świeżymi a związanymi materiałami są nieznaczne. Nie ma tu 
wyraźnej zależności pH od postaci przebadanych materiałów; w cześci przypadków wartości stężenia jonów wodorowych są wyższe dla kitów związanych (Italstucco, BEVA Gesso-V, klejowo-kredowy modyfikowany), natomiast w pozostałych przypadkach sytuacja wygląda odwrotnie - nieco wyższe wartości pH wykazują kity świeże (Tikkurila, Modostuc, „wiedeński”). Spośród przebadanych kitów najniższe wartości pH wykazał kit nr 7 - klejowo-kredowy modyfikowany (zarówno przed: 6,9, jak i po związaniu i sezonowaniu: 7,1), a najwyższe kit nr 5 - BEVA Gesso- $V$ (odpowiednio: 8,5 i 8,7). Badane kity można ułożyć w rosnącym pod względem zasadowości szeregu w następujący sposób:

nr 7 - kredowo-klejowy modyfikowany (odczyn obojętny),

nr 4 - BEVA Gesso-P,

nr 6 - emulsyjny „wiedeński”,

nr 2 - Italstucco,

nr 3 - Modostuc,

nr 1 - Tikkurila,

nr 5 - BEVA Gesso-V (odczyn słabo zasadowy).

Należy stwierdzić, że mimo obecności w składzie kitów spoiw o wyraźnie kwaśnym odczynie (jak polioctan winylu), pH gotowych preparatów jest zasadowe, co zapewne jest wynikiem użycia alkalicznych wypełniaczy $\left(\mathrm{CaCO}_{3}\right.$, $\mathrm{CaSO}_{4}$ ), skutecznie obniżających kwasowość. Wszystkie kity pod względem odczynu pH są materiałami bezpiecznymi dla podłoża płóciennego.

\subsection{Badania adhezji kitów do podłoża płóciennego}

Badanie adhezji kitów do płótna wykonano na zrywarce Machine for fleksural and tensile tests on the cements. Code MO52 (RMU Testing Equipment Bergamo, Włochy).

\subsubsection{Badanie adhezji kitów do nowego płótna (imitującego uzupełnienia ubytków podobrazia)}

Przygotowanie próbek do badań:

Płótnolniane zdekatyzowane i przeklejone 2\% metylocelulozą pocięto na kwadraty o wymiarach $60 \mathrm{~mm} \times 60 \mathrm{~mm}$, które naklejono na kostki drewniane klejem termoplastycznym i dodatkowo przy krawędziach przytwierdzono 
za pomocą zszywek tapicerskich. Na tak przygotowane płótno naniesiono próbki kitów o jednakowych wymiarach, posługując się szablonem o grubości $0,5 \mathrm{~mm}$ z wyciętym otworem o wymiarach $40 \mathrm{~mm} \times 40 \mathrm{~mm}$, i pozostawiono do sezonowania w warunkach normalnych przez trzy tygodnie. Po tym czasie do powierzchni kitów przyklejono stalowe „grzybki” (krążki o grubości $5 \mathrm{~mm}$ i promieniu $14 \mathrm{~mm}$ wytoczone wraz z walcowatym bolcem, z przewierconym na końcu otworem, służącym do zamocowania "grzybka” w uchwycie zrywarki). W celu przytwierdzenia próbek do powierzchni „grzybków” rozprowadzano na nich warstwę polioctanu winylu, a po jej nieznacznym podeschnięciu (po uzyskaniu odlipu) „grzybki” z naniesionym spoiwem przymocowywano do próbek kitów. Próbki każdego rodzaju kitu wykonano w trzech powtórzeniach oznaczonych I, II, III. Tak przygotowany układ pozostawiano do całkowitego wyschnięcia kleju. Po upływie 48 godzin umieszczano kolejno próbki w uchwycie zrywarki, przystępując do odrywania metalowych „grzybków”, wraz z przyklejonymi do ich powierzchni kitami, od podłoża płóciennego. Po uruchomieniu urządzenia na próbkę działała płynnie zwiększająca się siła zrywająca, której wartość odczytywano na poziomej skali.

\subsubsection{Badanie adhezji kitów do płótna przesyconego masą woskowo-żywiczną}

Przygotowanie próbek do badań:

Stare płótno dublażowe oczyszczono z nadmiarów masy woskowo-żywicznej (mechanicznie i przez wytapianie gorącym żelazkiem), a następnie pocięto na kwadraty o wymiarach $60 \mathrm{~mm} \times 60 \mathrm{~mm}$. Dalszy ciąg metodyki przygotowania próbek identyczny jak w punkcie 2.7.1. 
Wyniki badań:

Tab. 7. Wartości zarejestrowane przy próbach zrywania kitów z płócien przeklejonych MC i przesyconych masą woskowo-żywiczną

\begin{tabular}{|l|c|c|c|}
\hline Rodzaj kitu & Powtórzenie & $\begin{array}{c}\text { Przyczepność do płótna } \\
\text { przeklejonego MC } \\
\text { [daN] }\end{array}$ & $\begin{array}{c}\text { Przyczepnośćdo płótna } \\
\text { przesyconego masa } \\
\text { woskowo-zywiczna [daN] }\end{array}$ \\
\hline \multirow{3}{*}{ 1.Tikkurila } & I & 41 & 30 \\
& II & 45 & 24 \\
\hline \multirow{3}{*}{ 2. Italstucco } & III & 58 & 36 \\
\hline \multirow{3}{*}{ 3. Modostuc } & II & 35 & 23 \\
& III & 23 & 25 \\
\hline \multirow{3}{*}{ 4. BEVA Gesso-P } & I & 33 & 26 \\
\hline \multirow{3}{*}{ 5. BEVA Gesso-V } & III & 22 & 21 \\
& I & 23 & 22 \\
\hline \multirow{3}{*}{ 6. ,Wiedeński" } & III & 31 & 24 \\
\hline \multirow{3}{*}{ 7. Klejowo-kredowy } & II & 29 & 23 \\
& III & 35 & 22 \\
& II & 37 & 23 \\
\hline
\end{tabular}

Podsumowanie wyników badań i wnioski:

Obliczenia wykonano, dzieląc wartość odpowiadająca powierzchni „grzybka” (tj. koła) przez wskazania odczytane na skali urządzenia. W ten sposób oznaczono siłe, której należało użyć, aby oderwać od płótna kit o powierzchni $1 \mathrm{~cm}^{2}$.

$F_{\text {koła }}=\Pi r^{2}$

$\Pi=3,14$

$r=1,4 \mathrm{~cm}$

$\Pi r^{2}=3,14 \cdot 1,4 \mathrm{~cm} \cdot 1,4 \mathrm{~cm}=6,15 \mathrm{~cm}^{2}$

Wyniki zestawione w poniższej tabeli są średnią z trzech pomiarów. 
Tab. 8. Zestawienie wyników badań adhezji kitów do różnych rodzajów płótna

\begin{tabular}{|l|c|c|}
\hline \multicolumn{1}{|c|}{ Rodzaj kitu } & $\begin{array}{c}\text { Adhezja kitu } \\
\text { do płótna przeklejonego MC } \\
{\left[\mathrm{daN}_{\mathrm{cm}}{ }^{2}\right]}\end{array}$ & $\begin{array}{c}\text { Adhezja kitu do płótna przesyconego } \\
\text { masą woskowo-żywiczną } \\
{\left[\mathrm{daN} / \mathrm{cm}^{2}\right]}\end{array}$ \\
\hline 1. Tikkurila & 7,81 & 4,88 \\
\hline 2. Italstucco & 4,93 & 4,01 \\
\hline 3. Modostuc & 3,79 & 3,63 \\
\hline 4. BEVA Gesso-P & 5,15 & 3,74 \\
\hline 5. BEVA Gesso-V & 5,42 & 4,71 \\
\hline 6. „Wiedeński” & 8,67 & 7,64 \\
\hline 7. Klejowo-kredowy & 3,63 & 2,71 \\
\hline
\end{tabular}

Wartości uwidocznione w tabeli 8 odpowiadają sile, której należało użyć, aby doprowadzić do utraty sztywności układu podłoże-kit, co w praktyce oznacza początkowy moment odrywania kitu od płótna. Zestawienie wyników badań adhezji kitów do płótna przeklejonego metylocelulozą oraz przesyconego masą woskowo-żywiczną pokazuje, że te same kity mają gorszą przyczepność do drugiego z wymienionych płócien. Oznacza to, że pozostałości masy woskowo-żywicznej we włóknach tworzą swego rodzaju izolację, wpływającą na obniżenie adhezji do płótna wszystkich badanych materiałów. W obu grupach największą przyczepnością charakteryzują się kity nr 6 „wiedeński” i nr 1 - Tikkurila, nieco mniejszą nr 5 i nr 4 - BEVA Gesso-P i BEVA Gesso-V oraz nr 2 - Italstucco, a kity nr 3 - Modostuc i nr 7 - klejowo-kredowy zamykają ten szereg. W trakcie badań stwierdzono także, że kity nr 4 i 5 - BEVA Gesso-P i BEVA Gesso-V (a szczególnie ten drugi) - na skutek przewagi sił adhezji nad siłami kohezji przejawiały tendencje do rozwarstwiania się w masie. Pozostałe kity oddzielały się od płótna w całej grubości.

Jako uzupełnienie opisanych badań wykonano testy, polegające na podważaniu krawędzi próbek za pomocą skalpela. Porównawczej ocenie poddawano siłe, niezbędną do oddzielenia kitu od płótna, wielkość odrywanych fragmentów, wygląd płótna po usunięciu z niego kitu, a także wygląd powierzchni kitu przylegającej do podłoża. Wszystkie rodzaje oderwanych od płótna kitów miały na odwrociu odwzorowanie splotu płótna, co oznacza, że wszystkie badane materiały dobrze zwilżają i przylegają do fakturalnej powierzchni płótna. Użycia największejsiły ( „z pewnym trudem”) do oderwania 
od podłoża wymagały dwa kity: nr 1 - Tikkurila i nr 6 - „wiedeński”, których przyczepność do płótna jest bardzo dobra (obserwacje te potwierdzają wyniki uzyskane na zrywarce) i które w trakcie podważania skalpelem pękają i łamią się na małe kawałki, a po ich usunięciu powierzchnia płótna jest czysta i nie zawiera pozostałości kitu. Dobrą przyczepnością do płótna charakteryzują się kity nr 2 - Italstucco, nr 3 - Modostuc i nr 7 - klejowo-kredowy, jednak ich oderwanie od płótna nie było tak trudne jak w przypadku kitów nr 1 i nr 6 . Wszystkie trzy kity po usunięciu pozostawiają zabielenia na płótnie. Kit nr 7 pęka i odrywa się podobnie jak kity nr 1 i nr 6 (w postaci małych kawałków), kity nr 2 i nr 3, pękając, tworzą mniejsze poletka. Kity nr 4 i nr 5 - BEVA Gesso-P i BEVA Gesso-V - przylegają do płótna dość dobrze, a ich usunięcie nie nastręcza większych problemów. Kit nr 4 przy podważaniu skalpelem nie pęka i daje się odrywać w większych fragmentach (wielkości 1/4-1/3 całej próbki), nie pozostawiając na powierzchni płótna żadnych śladów. Kit nr 5 nie ma już tak zwartej budowy, pozwalając na odrywanie jedynie w mniejszych kawałkach, które miękko oddzielają się od sąsiadujących części, pozostawiając pomiędzy włóknami płótna resztki substancji.

\subsection{Badania elastyczności kitów}

Materiały użyte do badań:

1. Kity oznaczone numerami od 1 do 5 oraz 7.

2. Kit emulsyjny „wiedeński” (nr 6) sporządzony w czterech wariantach o składzie (we wszystkich):

15\% PAW - 1 cz. wag.,

3\% MC - 1 cz. wag.,

kreda szampańska - 3 cz. wag.,

ponadto:

6a: 25\% mastyks w olejku terpentynowym - 0,2 cz. wag., terpentyna wenecka - 0,1 cz. wag., 6b: 25\% mastyks w olejku terpentynowym - 0,3 cz. wag., terpentyna wenecka - 0,15 cz. wag.,

6c: kreda szampańska - dodatkowo 0,5 cz. wag., 25\% mastyks w olejku terpentynowym - 0,3 cz. wag., terpentyna wenecka - 0,15 cz. wag., 
6d: 25\% mastyks w olejku terpentynowym - 0,4 cz. wag., terpentyna wenecka - 0,2 cz. wag.

3. Płótno lniane.

Przygotowanie próbek do badań:

Zdekatyzowane i przeklejone 2\% metylocelulozą płótno lniane napięto na sztywną płyte pilśniową. Płaszczyznę płótna podzielono poziomymi i pionowymi liniami na jednakowe prostokąty o wymiarach $100 \mathrm{~mm} \times 50 \mathrm{~mm}$, pośrodku których naniesiono próbki kitów. W tym celu posłużono się szablonem z blachy miedzianej o grubości $0,5 \mathrm{~mm}$, w której wycięto otwór o wymiarach $50 \mathrm{~mm} \times 20 \mathrm{~mm}$. Wszystkie próbki po ich wyschnięciu sezonowano przez cztery tygodnie w warunkach panujących w pracowni, po czym płótno z kitami rozcięto wzdłuż wcześniej wyznaczonych linii na poszczególne prostokątne próbki. Dla każdego rodzaju kitu przygotowano po dziewięć próbek. Badania wykonano na trzech grupach kitów:

A) przechowywanych w warunkach powietrzno-suchych (cztery tygodnie w temp. $20^{\circ} \mathrm{C}$ i RH $35-45 \%$ );

B) poddawanych nawilżaniu $\mathrm{w}$ komorze wilgotnościowej $\mathrm{w}$ temp. $20^{\circ} \mathrm{C}$ i RH 100\% przez okres tygodnia;

C) poddawanych przesuszaniu przez 20 godzin w suszarce, w której panowała temp. $35^{\circ} \mathrm{C}$.

Próbki kitów na płótnie wyginano na walcach o różnych średnicach [cm]: 19,$0 ; 14,0 ; 12,5 ; 11,0 ; 8,0 ; 7,0 ; 5,0 ; 3,0$, rozpoczynając badanie od walca o największej średnicy, stopniowo ją zmniejszając, aż do pojawienia się spękań na badanej próbce. W dalszej kolejności wykonywano jeszcze badanie na walcu o średnicy mniejszej o jeden stopień, aby określić, w jaki sposób spękania się powiększają. Nie kontynuowano badań na walcach o niższych średnicach.

\subsubsection{Badanie elastyczności kitów sezonowanych w warunkach powietrzno-suchych}

Po czterech tygodniach przechowywania próbek w warunkach laboratoryjnych (ok. $20^{\circ} \mathrm{C}, 35-45 \%$ wilgotności względnej powietrza) przystąpiono do wyginania ich na walcach.

Omówienie wyników i wnioski:

Badane próbki zachowywały się w zróżnicowany sposób: od zdecydowanego pękania na walcach o największych średnicach, przez stopniowe 
pojawianie się spękań w trakcie zmniejszania średnicy walców, do zachowania niezmienionej postaci. Brakiem spękań i najlepszą elastycznością wykazały się kity nr 4 i nr 5, najgorzej w badaniu wypadły kity nr 7 i nr 6, które pękały pośrodku w całej grubości i szerokości próbek już w trakcie wyginania na walcach o największej średnicy. Zmniejszenie walca spowodowało zwiększanie się liczby spękań do trzech. W nieco inny sposób, nie tak gwałtownie, tworząc pojedyncze drobne rysy, pękały próbki kitu nr 3, jednakże następowało to również podczas wyginania na największym walcu. Użycie mniejszego walca sprawiało, że spękania powiększyły się i wzrosła ich liczba. Kity nr 2 i nr 1 pękały w sposób podobny do kitu nr 3, ale dopiero na walcach o pośrednich średnicach (odpowiednio 8 i $11 \mathrm{~cm}$ ), wykazując się dostateczną elastycznością.

\subsubsection{Badanie elastyczności kitów po nawilżaniu w komorze wilgotnościowej}

Po czterech tygodniach sezonowania próbek w warunkach powietrzno-suchych (identycznie jak w punkcie 2.8.1) umieszczono je w komorze wilgotnościowej, gdzie panowały warunki: $20^{\circ} \mathrm{C}$ i $100 \% \mathrm{RH}$, na okres jednego tygodnia. Próbki wyjmowano pojedynczo i naciagano na walce w taki sam sposób jak próbki z grupy A.

Omówienie wyników i wnioski:

Większość badanych kitów wykazała się dobrą lub bardzo dobrą elastycznością. Kity nr 4, nr 5 i nr 6 a nie popękały nawet w trakcie naciągania ich na walce o najmniejszej średnicy wynoszącej 3,0 cm. Kity z grupy nr 6 (w czterech wariantach zróżnicowanych pod względem ilościowym tych samych składników) wykazały nieznaczne różnice na korzyść mieszaniny o najmniejszej zawartości żywic naturalnych (6a), gdzie spękania nie pojawiły się wcale (il. 8). Trzy pozostałe (6b, 6c, 6d) zaczynały nieznacznie pęká na walcach o średnicach 5,0 i 3,0 cm (z wyjątkiem jednej próbki z grupy 6b). Trudno jednoznacznie stwierdzić, że elastyczność tego kitu spada wraz ze wzrostem procentowej zawartości żywic w jego składzie, gdyż obserwacje nie pozwalaja na określenie pewnej prawidłowości w tym względzie (np. na jednej z próbek nr $6 \mathrm{~d}$ o największej zawartości żywic spękania nie wystąpiły, podczas gdy na próbce $\mathrm{nr} 6 \mathrm{~b}$ z mniejszym ich udziałem pojawiły się już przy badaniu na walcu o średnicy $8,0 \mathrm{~cm}$ - co mogło być spowodowane zbyt gwałtownym 
wygięciem próbki). Zbliżoną do kitów nr 6 elastycznością wykazały się próbki kitu nr 2 (spekkania na walcach o średnicach 7,0 i 5,0 cm), a nieco mniejszą próbki kitu nr 3 (drobne spękania na walcach o średnicach 8,0 i 7,0 cm). Kity nr 1 zaczynały pękać podczas wyginania ich na walcach o średnicach 11,0 i 8,0 cm. Najniższą elastycznością wykazał się kit nr 7, który gwałtownie popekkał wyginany na największym walcu $(19,5 \mathrm{~cm})$, tworząc całą siatkę głębokich spekkań (il. 9).

\subsubsection{Badanie elastyczności kitów po ich przesuszeniu}

Po czterech tygodniach sezonowania próbek w warunkach powietrzno-suchych (identycznie jak w punkcie 2.8.1) umieszczono je na $20 \mathrm{~h}$ w suszarce, w temperaturze $35^{\circ} \mathrm{C}$. Próbki wyjmowano pojedynczo i naciągano na walce w taki sposób jak próbki z grup A i B.

Omówienie wyników i wnioski:

Należy odnotować pewne zróżnicowanie w zachowaniu się kitów w trakcie badań. Próbki kitów nr 4 i nr 5 nie popęały podczas zmniejszania średnicy walców do najmniejszej, wykazując tym samym najlepszą elastyczność (il. 10). Na największym z użytych walców utworzyły się głębokie i liczne spękania w próbkach kitu nr 7 , rozpoczęły pękanie wszystkie kity z grupy nr 6, tworząc dość dużo spękań. Pojedyncze drobne spękania zarysowały się także na największym walcu w próbkach kitów nr 2 i nr 3. Kit nr 1 nieznacznie pękał na walcach o średnicach 11,0 i 8,0 cm.

Podsumowanie wyników badań (zob. tab. 9) i wnioski:

Poszczególne rodzaje kitów różnią się znacznie między sobą właściwością, jaką jest elastyczność. $Z$ analizy zestawienia wyników badań w poszczególnych grupach (tab. 9) wynika, że najlepsze rezultaty pod tym względem uzyskano w grupie B, gdzie kity zostały poddane nawilżaniu w komorze wilgotnościowej. Nawilżone kity znacznie zyskują na elastyczności w stosunku do tych, które były przechowywane w warunkach panujących w pracowni. Kity z grupy C - poddane przesuszeniu - w cześci przypadków tracą na elastyczności (spekkania pojawiają się w trakcie wyginania ich na walcach o większej średnicy niż przy badaniach analogicznych kitów w grupie A) lub nie zmieniaja jej zasadniczo. Bezkonkurencyjne okazały sie we wszystkich grupach kity nr 4 i nr 5 BEVA Gesso-P i BEVA Gesso- $V$, które nawet po przesuszeniu nie pekały na walcach o najmniejszej, liczącej $3,0 \mathrm{~cm}$, średnicy. 
Tab. 9. Zestawienie wyników badań elastyczności kitów przechowywanych w różnych warunkach temperatury i wilgotności

\begin{tabular}{|c|c|c|c|}
\hline \multirow{2}{*}{ Rodzaj kitu } & $\begin{array}{c}\text { Warunki } \\
\text { powietrzno-suche }\end{array}$ & $\begin{array}{c}\text { Nawilżanie w komorze } \\
\text { wilgotnościowej }\end{array}$ & Przesuszanie w suszarce \\
\hline & \multicolumn{3}{|c|}{ średnica walca, którego użycie powoduje powstawanie spękań [cm] } \\
\hline 1. Tikkurila & $\begin{array}{l}12,5-++ \\
11,0--+\end{array}$ & $\begin{array}{l}11,0-++ \\
8,0--+\end{array}$ & $\begin{array}{l}11,0-++ \\
8,0--+\end{array}$ \\
\hline 2. Italsucco & $\begin{array}{l}8,0-++ \\
7,0--+\end{array}$ & $\begin{array}{l}7,0-++ \\
5,0--+\end{array}$ & $\begin{array}{l}19,0-++ \\
14,0--+\end{array}$ \\
\hline 3. Modostuc & $\begin{array}{l}19,0-++ \\
14,0--+\end{array}$ & $\begin{array}{l}8,0-++ \\
7,0--+\end{array}$ & $\begin{array}{l}19,0-++ \\
14,0--+\end{array}$ \\
\hline 4. BEVA Gesso-P & $(0)+++$ & $(0)+++$ & $(0)+++$ \\
\hline 5. BEVA Gesso-V & $(0)+++$ & $(0)+++$ & $(0)+++$ \\
\hline 6a. „Wiedeński” & $\begin{array}{l}19,0--+ \\
14,0---\end{array}$ & $(0)+++$ & $\begin{array}{l}19,0--+ \\
14,0---\end{array}$ \\
\hline 6b. „Wiedeński” & $\begin{array}{l}19,0--+ \\
14,0---\end{array}$ & $\begin{array}{l}5,0-++ \\
3,0--+\end{array}$ & $\begin{array}{l}19,0--+ \\
14,0---\end{array}$ \\
\hline 6c. „Wiedeński” & $\begin{array}{l}19,0--+ \\
14,0---\end{array}$ & $\begin{array}{l}5,0-++ \\
3,0--+\end{array}$ & $\begin{array}{l}19,0--+ \\
14,0---\end{array}$ \\
\hline 6d. „Wiedeński & $\begin{array}{l}19,0--+ \\
14,0---\end{array}$ & $\begin{array}{l}5,0-++ \\
3,0--+\end{array}$ & $\begin{array}{l}19,0--+ \\
14,0---\end{array}$ \\
\hline 7. Klejowo-kredowy & $\begin{array}{l}19,0--+ \\
14,0---\end{array}$ & $\begin{array}{l}19,0--+ \\
14,0---\end{array}$ & $\begin{array}{l}19,0--+ \\
14,0---\end{array}$ \\
\hline
\end{tabular}

Objaśnienia:

- - - dużo głębokich spękań, brak elastyczności,

--+ dość dużo spękań, mała elastyczność,

-++ pojedyncze, drobne spekania, kit elastyczny,

+++ brak spękań, kit bardzo elastyczny.

Na przeciwnym biegunie trzeba umieścić kit nr 7 klejowo-kredowy, który w grupach A, B i C pękał twardo już na walcach o średnicy 19,0 cm, w grupie A i C tworząc równoległe do osi walca głębokie spękania o równych krawędziach, a w grupie B rysując siatkę pęknięć biegnących w różnych kierunkach. Kit nr 6 „wiedeński” - we wszystkich wariantach - w grupach A i $\mathrm{C}$ zachowywał się dosyć podobnie, tj. pękał już podczas prób wyginania 
na największych walcach. Jednakże próby w grupie B wykazały dla tego kitu ogromną poprawę elastyczności - spękania pojawiały się tu dopiero przy wyginaniu na walcach o najniższych średnicach $(5,0$ i 3,0 cm). Wpływ na poprawę elastyczności kitu wywierają materiały higroskopijne - zarówno wypełniacze, jak i spoiwa, które wchodzą w jego skład. W odniesieniu do wszystkich czterech wariantów kitu nr 6 nie stwierdzono, aby zwiększenie udziału żywic naturalnych miało wyraźny wpływ na poprawę lub pogorszenie się elastyczności kitów. Różnice tej właściwości pomiędzy poszczególnymi wariantami próbek we wszystkich grupach były nieznaczne lub nie występowały wcale.

Dostateczną elastycznością wykazały się kity o numerach: 1 - Tikkurila, 2 - Italstucco i 3 - Modostuc, przy czym przechowywanie próbek w środowisku o zwiększonej wilgotności znacznie podwyższa tę ich właściwość. Wszystkie trzy rodzaje kitów pękają w zbliżony sposób, nie tak gwałtowny jak w przypadku kitów nr 7 i nr 6 (w grupach A i C); najpierw pojawiają się drobne rysy przy krawędziach, które w wyniku mocniejszego wygięcia stopniowo pogłębiają się, tworząc miękkie linie.

\subsection{Badania higroskopijności kitów}

Przyrost masy próbek kitów oznaczono w procentach.

\subsubsection{Badanie higroskopijności kitów uformowanych w kształtki}

Materiały użyte do badań:

1. Kity oznaczone numerami od 1 do 7.

2. Foremki stalowe.

3. Eksykator z wodą destylowaną.

Przygotowanie próbek do badań:

W celu uniknięcia zafałszowania pomiarów przez skraplającą się na nośnikach próbek parę wodną wykonano z kitów kształtki w formie prostopadłościanów. Foremki stalowe o wymiarach $25 \mathrm{~mm} \times 10 \mathrm{~mm} \times 10 \mathrm{~mm}-$ po trzy dla każdego rodzaju kitu - wypełniono masami kitującymi i pozostawiono do wyschnięcia w warunkach normalnych. Po upływie dwóch tygodni kształtki rozformowano, dosuszono w suszarce próżniowej w temp. $50^{\circ} \mathrm{C}$ 
( 24 godziny) i przełożono do eksykatora z suchym żelem krzemionkowym, po czym próbki ważono kolejno na wadze analitycznej w naczyńkach wagowych, a następnie zważone próbki umieszczano w „mokrym” eksykatorze $\left(\sim 100 \%\right.$ wilgotności względnej powietrza i temp. $\left.20^{\circ} \mathrm{C}\right)$.

Wyniki badań:

Ważenie próbek wykonywano co kilka dni na pełnoautomatycznej elektrycznej wadze analitycznej z dokładnością 0,0001 mg. Jednakże już w trakcie drugiego pomiaru stwierdzono, że niektóre nawilżone próbki wykazują tendencje do kruszenia się podczas wyjmowania ich z eksykatora i naczyńka. Fakt ten uniemożliwił prowadzenie dalszych badań, które zostałyby zafałszowane. W związku z tym w tabeli 10 podano jedynie wyniki dwóch pierwszych pomiarów.

Procentowy wzrost masy obliczono ze wzoru:

$$
H=\left(m-m_{\mathrm{o}}\right) / m_{\mathrm{o}} \cdot 100 \%,
$$

gdzie: $H$ - higroskopijność,

$m_{\mathrm{o}}$ - masa próbki suchej,

$m$ - masa próbki wilgotnej.

Tab. 10. Procentowy wzrost masy kitów w kształtkach po nawilżaniu

\begin{tabular}{|l|c|c|}
\hline \multirow{2}{*}{ Rodzaj kitu } & \multicolumn{2}{|c|}{ Przyrost masy próbek (średnia z trzech pomiarów) [\%] } \\
\cline { 2 - 3 } & po dwóch dniach & po sześciu dniach \\
\hline 1. Tikkurila & 3,747 & 5,241 \\
\hline 2. Italstucco & 2,509 & 4,054 \\
\hline 3. Modostuc & 2,344 & 4,730 \\
\hline 4. BEVA Gesso-P & 0,386 & 0,521 \\
\hline 5. BEVA Gesso-V & 1,108 & 2,166 \\
\hline 6. „Wiedeński” & 4,371 & 5,318 \\
\hline 7. Klejowo-kredowy & 2,645 & 4,342 \\
\hline
\end{tabular}

Najwyższą higroskopijność wykazały kity nr 6 i nr 1, nieco mniejszą nr 3, nr 7 i nr 2, niewielką kit nr 5, a całkiem znikomą kit nr 4. Przebieg badań wskazuje, że wzrost higroskopijności wpływa na osłabienie odporności mechanicznej niektórych kitów. Obserwacja ta dotyczy kitów nr 1 - Tikkurila i 2 - Italstucco, których krawędzie kształtek kruszyły się już podczas 
delikatnego ujmowania ich i przemieszczania z naczynia do naczynia. Przeprowadzenie wiarygodnych badań jest możliwe w tym przypadku jedynie dzięki zastosowaniu nośnika dla kitów, pozwalającego na manewrowanie próbkami bez konieczności bezpośredniego ich dotykania.

\subsubsection{Badanie higroskopijności kitów naniesionych na szkiełka przedmiotowe}

Przygotowanie próbek do badań:

Jako nośnik kitów wybrano szkiełka przedmiotowe. Przygotowano po trzy takie szkiełka dla każdego rodzaju kitu: oznaczono i zważono na wadze analitycznej, a następnie naniesiono na nie badane materiały. Kity nanoszono za pomocą szablonu wykonanego z blachy miedzianej o grubości 0,5 $\mathrm{mm}$, z wyciętym otworem o wymiarach $20 \mathrm{~mm} \times 50 \mathrm{~mm}$, a następnie pozostawiono $w$ warunkach normalnych przez trzy tygodnie. Po upływie tego czasu próbki umieszczono w suszarce próżniowej i dosuszano pod ciśnieniem -1 atmosfery w temperaturach: $50^{\circ} \mathrm{C}\left(\sim 25\right.$ godzin), $20^{\circ} \mathrm{C}(\sim 140$ godzin). Bezpośrednio po wyjęciu próbek z suszarki umieszczono je w eksykatorze z żelem krzemionkowym, a następnie pojedynczo ważono je w naczyńku wagowym i wkładano do stojaka z tworzywa sztucznego, umożliwiającego pionowe ustawienie szkiełek w „mokrym” eksykatorze (w warunkach: wilgotność względna powietrza ok. $100 \%$, temp. ok. $20^{\circ} \mathrm{C}$ ). Przyrost ciężaru próbek mierzono w odstępach kilkudniowych przez okres dwóch tygodni, aż do ustalenia się stałej masy. Pomiary były dokonywane na pełnoautomatycznej elektrycznej wadze analitycznej z dokładnością 0,0001 mg. Wyniki badań:

Procentowy wzrost masy obliczono identycznie jak w punkcie 2.9.1 ze wzoru:

$$
H=\left(m-m_{\mathrm{o}}\right) / m_{\mathrm{o}} \cdot 100 \% .
$$


Tab. 11. Procentowy wzrost masy kitów założonych na szkiełka przedmiotowe po nawilżaniu

\begin{tabular}{|l|c|c|c|c|c|}
\hline \multirow{2}{*}{ Rodzaj kitu } & \multicolumn{5}{|c|}{ Przyrost masy próbek [\%] ('́rednia z trzech pomiarów) } \\
\cline { 2 - 6 } & po 2 dniach & po 7 dniach & po 10 dniach & po 14 dniach & po 16 dniach \\
\hline 1. Tikkurila & 3,935 & 7,683 & 8,295 & 8,481 & 8,481 \\
\hline 2. Italstucco & 3,376 & 4,981 & 5,050 & 5,536 & 5,536 \\
\hline 3. Modostuc & 2,997 & 4,393 & 4,560 & 4,908 & 4,908 \\
\hline 4. BEVA Gesso-P & 0,184 & 0,316 & 0,376 & 0,427 & 0,427 \\
\hline 5. BEVA Gesso-V & 0,549 & 1,164 & 1,691 & 1,787 & 1,787 \\
\hline 6. „Wiedeński” & 2,784 & 5,476 & 6,061 & 6,413 & 6,413 \\
\hline 7. Klejowo-kredowy & 4,048 & 6,377 & 7,864 & 8,877 & 8,877 \\
\hline
\end{tabular}

Omówienie wyników i wnioski:

Higroskopijność badanych kitów jest bardzo zróżnicowana i zawiera się w szerokim zakresie od 0,427\% do 8,877\%. Najmniejsze wartości charakteryzują kity BEVA Gesso-P $(0,427 \%)$ i BEVA Gesso-V (1,787\%), które nieznacznie chłona pare wodną (zwłaszcza BEVA Gesso-P). Dla następnych kitów wskazania są już kilkakrotnie wyższe: Modostuc (4,908\%), Italstucco (5,536\%), „wiedeński" (6,413\%). Najbardziej higroskopijne spośród przebadanych okazały się kity klejowo-kredowy i Tikkurila o wartościach przekraczających 8\% (odpowiednio: 8,887\% i 8,481\%).

\subsection{Badania chłonności i zwilżalności kitów}

Badania chłonności i zwilżalności kitów przeprowadzono z użyciem mikrodozymetru. Wielkość dozowanej kropli wynosiła $20 \mu$ l.

\subsubsection{Badanie chłonności i zwilżalności kitów nieizolowanych}

Przygotowanie próbek do badań:

Próbki kitów naniesiono na szkiełka przedmiotowe za pomocą szablonu z blachy miedzianej o grubości $0,5 \mathrm{~mm}$, z wyciętym otworem o wymiarach $50 \mathrm{~mm} \times 20 \mathrm{~mm}$. Próbki pozostawiono do sezonowania na okres czterech tygodni w warunkach laboratoryjnych, po czym powierzchnie kitów wyszlifowano.

Wyniki badań: 
Badania polegały na mierzeniu czasu wchłaniania przez kit kropli wody, dozowanej mikropipeta, do całkowitego wchłonięcia (lub całkowitego odparowania) oraz pomiarach zasięgu rozprzestrzeniania się kropli. Zrezygnowano z zabarwiania wody farbą akwarelową lub pigmentem, gdyż cząstki pigmentu większe od porów kitów mogłyby ograniczać rozlewność i wnikanie kropli w strukturę kitu, co powodowałoby zafałszowanie wyników. Poszczególne próby w każdej grupie kitów były przeprowadzane jednocześnie, aby warunki badań były jak najbardziej zbliżone dla wszystkich rodzajów kitów. Szkiełka przedmiotowe z naniesionymi próbkami ułożono obok siebie w kolejności od 1 do 7 , a krople wody dozowano na nie po kolei co 15 sekund (był to czas potrzebny na opróżnienie i ponowne napełnienie mikropipety).

Zaobserwowano dość znaczne różnice pomiędzy poszczególnymi kitami, zarówno pod względem czasu wchłaniania kropli wody, jak i wielkości plamy, która utworzyła się po jej wchłonięciu na powierzchni kitu. Wyodrębniono trzy grupy. W pierwszej czas wchłaniania był najszybszy i wynosił 23-27 min, a rozlewność kropli była największa i średnica plamy wynosiła 8-10 mm - w tej grupie znalazły się kity nr 1, nr 2 i nr 7. Dla kitów z drugiej grupy czas wchłaniania był około trzy razy dłuższy i wynosił 70-73 min, a plama utworzona przez wnikającą kroplę miała średnice 6-7 $\mathrm{mm}$ - tę grupe reprezentują kity nr 6 i nr 3. Trzecia grupa to kity nr 4 i nr 5 o najniższej chłonności - czas pozostawania kropli wody na powierzchni w ich przypadku wynosił 119-124 min, a kropla wody nie rozlewała się ani nie wchłaniała, pozostając niezmienna aż do odparowania, i zwilżała obszar o średnicy 5-5,5 mm (il. 11). Stwierdzono także, że woda spęcznia powierzchnię kitów nr 2 i nr 6 . Po wyschnięciu powierzchnia kitu nr 6 mająca kontakt z wodą odzyskuje pierwotny wygląd, natomiast na analogicznej powierzchni kitu nr 2 zaobserwowano utratę gładkości i zmiany w postaci mikrowgłębień.

\subsubsection{Badanie chłonności i zwilżalności kitów izolowanych werniksem retuszerskim}

Przygotowanie próbek do badań:

Identycznie jak w punkcie 2.10.1. Po czterech tygodniach sezonowania na wyszlifowane powierzchnie kitów naniesiono izolującą warstwę werniksu retuszerskiego damarowego (Talens, Holandia) i pozostawiono na 
okres tygodnia. Metodyka badań była identyczna jak w przypadku próbek nieizolowanych.

Wyniki badań:

Czas pozostawania kropli wody na powierzchniach wszystkich kitów jest bardzo długi i zawiera się w przedziale od 85 do 125 min. Jeszcze bardziej ujednolicone są wyniki badania zwilżalności kitów, gdyż na wszystkich próbkach kropla wody zwilżyła obszar w kształcie okręgu o średnicy $5 \mathrm{~mm}$. Krople wody wyglądają i zachowują się na wszystkich kitach identycznie, nie rozlewając się i bardzo wolno wnikając w głąb próbek (lub nie wnikając wcale), co najwyraźniej dzieje się za przyczyną izolacyjnej warstwy werniksu na powierzchni kitów. W momencie gdy stwierdzano zniknięcie kropli wody z powierzchni próbki, poddawano analizie wizualnej jej odwrocie, co było możliwe dzięki zastosowaniu szkiełka przedmiotowego jako nośnika, a także obserwowano próbkę w świetle przechodzącym. Na tej podstawie stwierdzono, że kity oznaczone numerami 1, 2, 3, 6 i 7 mimo warstwy izolacyjnej wchłaniają wode w głąb (tworzy się mokra plamka na odwrociu, odpowiadająca miejscu aplikowania kropli wody na powierzchni). Należy uznać, że pewna część kropli wody wnika w kity przez mikropory warstwy werniksu. Jednakże przy tak długim pozostawaniu na powierzchni z pewnością następuje odparowanie znacznej jej części. W przypadku kitów nr 4 i nr 5 wnikanie kropli wody w głąb próbek nie następuje wcale - odwrocia nie zostały zwilżone, a miejsca naniesienia kropli pozostały nieprzepuszczalne dla promieni świetlnych. Krople wody pozostają na powierzchniach tych kitów aż do całkowitego odparowania.

\subsubsection{Badanie chłonności i zwilżalności kitów izolowanych werniksem retuszerskim i przetartych żółcią wołową}

Przygotowanie próbek do badań:

Podobnie jak w punktach 2.10.1 i 2.10.2, z tą różnica, że po tygodniu sezonowania zawerniksowanych kitów przetarto je żółcią wołową, a bezpośrednio po jej wyschnięciu wykonano badania według identycznej, jak wyżej opisana, metodyki.

Wyniki badań: 
Między poszczególnymi rodzajami kitów występują tylko nieznaczne różnice pod względem czasu pozostawania kropli wody na powierzchni, który zawiera się między 30 (dla kitów nr 1 i nr 2) a 44 min (dla kitu nr 3). Krople wody naniesione na powierzchnie kitów zachowują się podobnie we wszystkich przypadkach: następuje natychmiastowe rozlanie się i zwilżenie znacznej powierzchni oraz utworzenie plamy, która nie jest idealnym owalem, a jedynie przypomina ten kształt. Wielkości tych plam są zróżnicowane, a średnice wynoszą od $10 \mathrm{~mm}$ dla kitu nr 3 do 14 dla kitów nr 4 i nr 5. Pośrednie wielkości dotyczą pozostałych kitów (il. 12). Obserwacja w świetle przechodzącym oraz analiza wizualna odwroci próbek po zniknięciu wody z ich powierzchni wykazała, że woda wnika całkowicie lub cześciowo w głąb próbek o numerach 1, 2, 3, 6 i 7, zwilżając także ich rewersy. Kity nr 4 i nr 5 nie wchłaniają wody w głąb - pozostaje ona na ich powierzchniach aż do odparowania.

Podsumowanie wyników badań i wnioski:

Tab. 12. Zestawienie wyników badań chłonności i zwilżalności kitów bez izolacji, pokrytych werniksem retuszerskim oraz pokrytych werniksem, który przetarto żółcią wołową

\begin{tabular}{|l|c|c|c|c|c|c|}
\hline \multirow{2}{*}{ Rodzaj kitu } & \multicolumn{3}{|c|}{$\begin{array}{c}\text { Czas pozostawania } \\
\text { kropli wody na powierzchni } \\
\text { [min] }\end{array}$} & \multicolumn{3}{c|}{$\begin{array}{c}\text { Średnica plamy utworzonej } \\
\text { przez kroplę wody } \\
\text { [mm] }\end{array}$} \\
\cline { 2 - 7 } & $\begin{array}{c}\text { kit bez } \\
\text { izolacji }\end{array}$ & $\begin{array}{c}\text { kit + } \\
\text { werniks } \\
\text { retuszerski }\end{array}$ & $\begin{array}{c}\text { kit + werniks } \\
+ \text { żółć } \\
\text { wołowa }\end{array}$ & $\begin{array}{c}\text { kit bez } \\
\text { izolacji }\end{array}$ & $\begin{array}{c}\text { kit + } \\
\text { werniks } \\
\text { retuszerski }\end{array}$ & $\begin{array}{c}\text { kit + werniks + } \\
\text { zółć wołowa }\end{array}$ \\
\hline 1. Tikkurila & 23 & 89 & 30 & 10 & 5 & 13 \\
\hline 2. Italstucco & 25 & 97 & 30 & 8 & 5 & 11 \\
\hline 3. Modostuc & 73 & 95 & 44 & 6 & 5 & 10 \\
\hline 4. BEVA Gesso-P & 119 & 125 & 40 & 5,5 & 5 & 14 \\
\hline 5. BEVA Gesso-V & 124 & 118 & 38 & 5 & 5 & 14 \\
\hline 6. „Wiedeński” & 70 & 85 & 39 & 7 & 5 & 11 \\
\hline 7. Klejowo-kredowy & 27 & 105 & 38 & 10 & 5 & 12 \\
\hline
\end{tabular}

Badane kity różnią się znacznie między sobą pod względem chłonności i zwilżalności. Różnice te są największe w grupie kitów nieizolowanych. Czas wchłaniania kropli wody przez najbardziej chłonne kity wynosi około 
dwadzieścia kilka minut, a najdłuższy czas pozostawania kropli wody na powierzchni przekracza dwie godziny. Najbardziej chłonne w tej grupie okazały się kity: Tikkurila, Italstucco i klejowo-kredowy, dla których czas wchłaniania kropli wody wynosił odpowiednio 23, 25 i 27 min. Ich zwilżalność jest także największa; naniesiona na powierzchnię kropla wody rozlewa się po niej szybko, wnika w głąb i zwilża obszar o średnicy odpowiednio: 10, 8 i $10 \mathrm{~mm}$. Niemal trzykrotnie dłuższe czasy wchłaniania charakteryzują kity „wiedeński” i Modostuc, wynosząc 70 i 73 min. Mniejsza jest także ich zwilżalność, wynosząca odpowiednio 7 i $6 \mathrm{~mm}$. Nieco inaczej w tym badaniu wypadły kity BEVA Gesso-P i BEVA Gesso-V, na powierzchni których krople wody pozostawały przez 119 i 124 min i zwilżały obszar o średnicach 5,5 i $5 \mathrm{~mm}$. Krople wody naniesione na te kity nie zmieniały swej formy przez kilkadziesiąt minut, nie rozlewały się prawie wcale (BEVA Gesso-P) lub wcale (BEVA Gesso- $V$ ) i nie przenikały w głąb kitów. Odnotowane wartości, określające czasy pozostawania kropli wody na powierzchni tych materiałów, należy raczej traktować jako wskazanie czasów odparowania kropli wody z ich powierzchni, a same kity uznać za niechłonne i niezwilżalne.

W grupie kitów zaizolowanych werniksem retuszerskim różnice w uzyskanych wynikach pomiędzy poszczególnymi materiałami są znacznie mniejsze. Należy stwierdzić, że pokrycie ich werniksem retuszerskim wpływa w znacznym stopniu na zwiększenie napięcia powierzchniowego i jednocześnie na zmniejszenie zdolności wchłaniania kropli wody przez większość badanych kitów (poza kitami BEVA Gesso-P i BEVA Gesso-V, których niska chłonność i zwilżalność nie ulegają tu zasadniczym zmianom), a także na obniżenie ich zwilżalności - wskazania dla wszystkich kitów wynoszą w tym przypadku $5 \mathrm{~mm}$ - krople na wszystkich wyglądają identycznie. Czasy pozostawania kropli wody na powierzchniach poszczególnych kitów są dosyć zbliżone i mieszczą się między 85 a 125 min. Najkrótsze czasy odnoszą się tu do kitu „wiedeńskiego” i Tikkurila, a najdłuższe ponownie do BEVA Gesso-P i BEVA Gesso- $V$, jednakże żadnego ze wskazań nie można uznać za zadowalające. Warstwa werniksu stanowi dla wszystkich materiałów dość szczelną izolacje, uniemożliwiającą (w przypadku kitów nr 4 i nr 5) lub w poważnym stopniu utrudniającą przeniknięcie kropli wody w głąb kitu (pozostałe kity).

Przetarcie żółcią wołową zaizolowanej werniksem retuszerskim powierzchni kitów w znacznym stopniu poprawia ich zwilżalność wodą. 
Obrazują to wyniki badania kitów w ostatniej grupie. Krople wody naniesione na powierzchnie kitów z grupy przetartej żółcią wołową rozlewają się natychmiast, często w sposób dość nieregularny (kity nr 4 i 5 - BEVA Gesso-P i BEVA Gesso-V), zwilżając obszar o średnicy od 10 do $14 \mathrm{~mm}$. Wyniki dotyczące badań chłonności wskazują, że dystans pomiędzy wskazaniami dla poszczególnych rodzajów kitów uległ znacznemu zmniejszeniu i czas pozostawania kropli wody na powierzchniach próbek mieści się w wąskim zakresie od 30 do 44 min. Jednakże w niektóre kity woda wnika cześciowo (Tikkurila, Italstucco, Modostuc, „wiedeński” i klejowo-kredowy) - co uwidacznia się na rewersie próbek lub przy obserwacji w świetle przechodzącym, natomiast inne (BEVA Gesso-P i BEVA Gesso-V) są zwilżane tylko powierzchniowo, a woda odparowuje całkowicie. Krótszy czas odparowania wody w stosunku do próbek nieizolowanych i izolowanych werniksem retuszerskim można wytłumaczyć faktem, że szeroko rozlane na skutek zwilżenia żółcią wołową krople wody mają większą powierzchnię parowania, co ułatwia i przyspiesza ten proces.

\subsection{Badania przyczepności retuszy do powierzchni kitów}

Badania przyczepności retuszy do powierzchni kitów określono według normy PN-73/C-81531 i wykonano za pomocą noża krążkowego - przyrządu ze stali narzędziowej (NC 4 wg PN-69/H-85023) - na obwodzie którego umieszczonych jest sześć równoległych ostrzy w jednej płaszczyźnie, w odstepach $2 \mathrm{~mm}$.

\subsubsection{Badanie przyczepności retuszy wykonanych farbami akwarelowymi}

Przygotowanie próbek do badań:

Próbki kitów naniesiono na podłoże szklane za pomocą szablonu z blachy miedzianej o grubości $0,5 \mathrm{~mm}, \mathrm{z}$ wyciętym otworem o wymiarach $50 \mathrm{~mm} \times 20 \mathrm{~mm}$. Po całkowitym wyschnięciu powierzchnie kitów wyszlifowano i pozostawiono próbki do sezonowania na okres trzech tygodni w warunkach powietrzno-suchych, po czym naniesiono na nie izolacje z werniksu retuszerskiego damarowego i pozostawiono na okres tygodnia. Po upływie 
tego czasu na powierzchnie kitów naniesiono pędzlem po dwie warstwy farby akwarelowej - ziemi zielonej. Tak przygotowane próbki pozostawiono w warunkach normalnych przez dwa tygodnie. Dla każdego rodzaju kitu przygotowano próbki w trzech powtórzeniach.

\subsubsection{Badanie przyczepności retuszy wykonanych farbami akrylowymi}

Przygotowanie próbek do badań:

Identycznie jak w punkcie 2.11.1, z tą różnica, że po sezonowaniu próbek z naniesionym werniksem retuszerskim powierzchnie kitów pokryto dwukrotnie farbą akrylową - ultramaryną.

Wyniki badań:

Na próbkach kitów z naniesionymi warstwami werniksu retuszerskiego i powłokami farb wykonano siatkę nacięć (rysując nożem - pod naciskiem dłoni - prostopadłe do siebie linie), a po zdmuchnięciu i oczyszczeniu siatki pędzlem przeprowadzono wizualną ocenę jej wyglądu, obserwując nacięcia przez lupkę. Spośród czterech stopni przyczepności przewidywanych przez normę - stopień pierwszy i drugi są uważane za dopuszczalne, a pozostałe dwa mają negatywną ocenę.

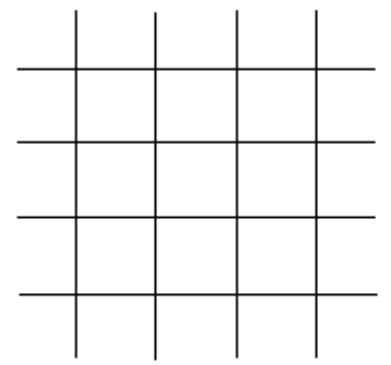

rys. $1 / 1$

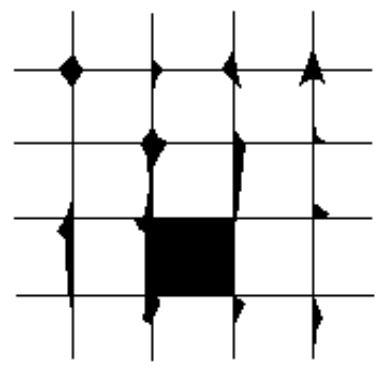

rys. $1 / 3$

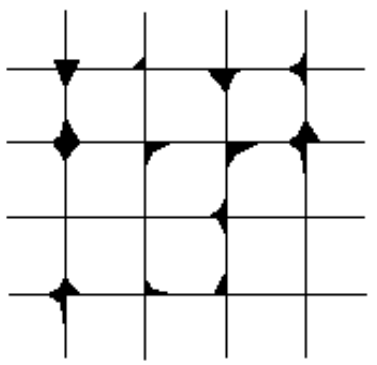

rys. $1 / 2$

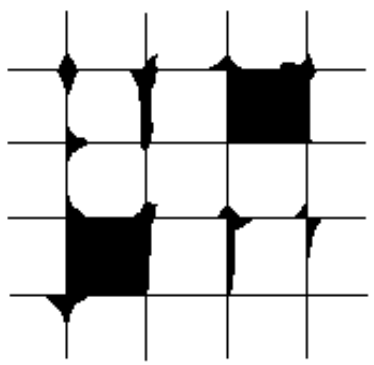

rys. $1 / 4$

Rys. 1. Wzór siatki nacięć służący do określania przyczepności powłok do podłoża 
Tab. 13. Skala przyczepności metodą siatki spękań

\begin{tabular}{|c|l|c|}
\hline $\begin{array}{c}\text { Stopień } \\
\text { przyczepności }\end{array}$ & \multicolumn{1}{|c|}{ Opis wyglądu siatki nacięć powłoki } & $\begin{array}{c}\text { Wzór siatki } \\
\text { nacięć }\end{array}$ \\
\hline 1 & brak odprysków powłoki, krawędzie nacięć gładkie & wg rys. 1/1 \\
\hline 2 & nieznaczne, punktowe odpryski powłoki przy krawędziach nacięćc & wg rys. 1/2 \\
\hline 3 & odpryski powłoki stanowiące ok. 35\% powierzchni & wg rys. 1/3 \\
\hline 4 & duże odpryski powłoki lub brak więcej niż 35\% powierzchni & wg rys. 1/4 \\
\hline
\end{tabular}

Podsumowanie wyników badań i wnioski:

Tab. 14. Określenie stopnia przyczepności powłok retuszy do powierzchni badanych kitów

\begin{tabular}{|l|c|c|}
\hline \multirow{2}{*}{ Rodzaj kitu } & \multicolumn{2}{|c|}{ Stopień przyczepności powłoki } \\
\cline { 2 - 3 } & akwarelowej & akrylowej \\
\hline 1. Tikkurila & 1 & 1 \\
\hline 2. Italstucco & 1 & 1 \\
\hline 3. Modostuc & 1 & $2-3$ \\
\hline 4. BEVA Gesso-P & $2-3$ & $2-3$ \\
\hline 5. BEVA Gesso-V & $2-3$ & 1 \\
\hline 6. „Wiedeński” & 1 & 2 \\
\hline 7. Klejowo-kredowy modyfikowany & $2-3$ & 1 \\
\hline
\end{tabular}

Na podstawie wizualnej analizy siatki nacięć wykonanych na powierzchniach kitów pokrytych powłokami retuszy stwierdzono, że zarówno powłoki farb akwarelowych, jak i akrylowych wykazują bardzo dobrą lub dobra przyczepność do większości badanych kitów. Przyczepność do kitów BEVA Gesso-P i BEVA Gesso-V oraz klejowo-kredowego, określona w tabeli 14 stopniem 2-3, oznacza, że nieznaczne odpryski powłoki znajdują się przy wszystkich krawędziach nacięć, jednakże ich łączna ilość jest mniejsza niż 35\%, plasuje się więc pomiędzy stopniem przyczepności 2 a 3 i można ją określić jako dostateczną. W przypadku niechłonnych i niezwilżalnych kitów BEVA Gesso poprawę przyczepności powłok retuszy mogłaby przynieść rezygnacja ze stosowania werniksu retuszerskiego. Przyczepność powłok retuszy do wszystkich kitów spełnia wymagania ustalone przez normę PN-73/C-81531. 


\section{Badania właściwości mikrobiologicznych}

\subsection{Badanie odporności materiałów na atak mikro- organizmów w warunkach podwyższonej wilgotności*}

Przygotowanie próbek do badań i warunki ich przechowywania:

Kity w cienkiej warstwie naniesiono na szkiełka przedmiotowe w dwóch powtórzeniach i pozostawiono do całkowitego wyschnięcia. Następnie próbki umieszczono w dużych szalkach Petriego, na dno których położono zwilżoną lignine, a na bagietkach szklanych tuż nad nią ułożono szkiełka z warstwą kitów i całość przykryto szalkami o większej średnicy. W ten sposób stworzono mikroklimat o wilgotności bliskiej 100\%. Tak przygotowane próbki umieszczono w cieplarce, w której panowała temperatura $20^{\circ} \mathrm{C}$.

Wyniki badań:

Badania prowadzono przez sześć miesięcy, obserwując próbki w następujący sposób: w pierwszym miesiącu co cztery dni, w drugim miesiącu raz w tygodniu, w trzecim miesiącu co dwa tygodnie, a następnie co miesiąc. Po upływie każdego pełnego miesiąca od założenia posiewu próbki oglądano pod mikroskopem.

Pierwsze objawy ataku mikroorganizmów zostały zauważone po upływie 16 dni na powierzchni jednej próbki kitu nr 7. Było to niewielkie ognisko grzybów o średnicy około $0,5 \mathrm{~cm}$ w postaci szarego puszystego nalotu. $\mathrm{Na}$ powierzchniach próbek pozostałych kitów o numerach od 1 do 6 stwierdzono atak mikrobiologiczny po upływie dwóch miesięcy podczas obserwacji pod mikroskopem. Miał on postać pojedynczych srebrzystoszarych strzepek grzybni bliżej nieokreślonego rodzaju. Taki stan utrzymywał się przez kolejny miesiąc na wszystkich sześciu kitach, po czym (po upływie czwartego miesiąca badań) stwierdzono bardziej intensywny rozwój mikroorganizmów na powierzchni próbek kitów nr 3 i nr 6, a po upływie piątego miesiąca także kitu nr 5. Na powierzchni pozostałych kitów o numerach 1, 2 i 4 nie stwierdzono w tym czasie zintensyfikowania rozwoju mikroflory.

* Badanie przeprowadzono w Zakładzie Konserwacji Papieru i Skóry Wydziału Sztuk Pięknych UMK w Toruniu pod kier. dr Joanny Karbowskiej. 
Omówienie wyników i wnioski:

Mikroorganizmy najszybciej, bo już po upływie dwóch tygodni, zaatakowały kit klejowo-kredowy. Biorąc pod uwagę fakt, iż jego spoiwem jest klej glutynowy, stanowiący doskonałą pożywkę dla mikroorganizmów, wynik taki jest zrozumiały i łatwy do przewidzenia. Dalsze obserwacje pozwoliły na stwierdzenie, że przy utrzymaniu warunków wysokiej wilgotności rozwój drobnoustrojów stopniowo postępuje. Należy także podkreślić, iż atak mikroorganizmów nie oszczędził żadnego z badanych kitów. W większości przypadków rozwijały się one bardzo powoli, a ich obecności nie sposób było stwierdzić nieuzbrojonym okiem. Przez kilkanaście tygodni występowały w formie strzępek grzybni - początkowo pojedynczych, a z czasem zagęszczających się, nie tworząc jednak zarodników (co uniemożliwiało określenie gatunku). Trzeba wobec powyższego zauważyć, że długotrwałe przebywanie wszystkich badanych kitów w warunkach bardzo wysokiej wilgotności prowadzi do ataku mikrobiologicznego, który - mimo iż dla różnych rodzajów kitów nie nasteppuje jednocześnie - jest jednak nieunikniony. W sprzyjających warunkach różne mikroorganizmy porastają wszystkie badane kity, jednakże ich rozwój przebiega w różnym nasileniu (il. 13-14). Ilustruje to poniższa tabela ${ }^{47}$.

Tab. 15. Oznaczenie drobnoustrojów na próbkach kitów po upływie 6 miesięcy

\begin{tabular}{|c|c|c|}
\hline Rodzaj kitu & $\begin{array}{l}\text { Rodzaj mikroorganizmów } \\
\text { i zmiany przez nie wywołane }\end{array}$ & Stopień rozwoju drobnoustrojów \\
\hline 1. Tikkurila & $\begin{array}{l}\text { - Aspergillus, } \\
\text { - ciemne strzepki z czarnymi tworami, } \\
\text { - żółte przebarwienia podłoża w postaci } \\
\text { niewielkich plamek }\end{array}$ & \begin{tabular}{l}
\multicolumn{1}{c}{+} \\
nieznaczny - pojedyncze kolonie \\
widoczne dopiero po dłuższym oglądzie, \\
najwyraźniej w powiększeniu
\end{tabular} \\
\hline 2. Italstucco & - Aspergillus & \begin{tabular}{l}
\multicolumn{1}{c}{+} \\
nieznaczny - pojedyncze kolonie \\
widoczne dopiero po dłuższym oglądzie, \\
najwyraźniej w powiększeniu
\end{tabular} \\
\hline 3. Modostuc & $\begin{array}{l}\text { - Aspergillus (bardzo liczne konidiofory), } \\
\text { - żółte lokalne przebarwienia na } \\
\text { powierzchni }\end{array}$ & \begin{tabular}{l}
\multicolumn{1}{c}{+++} \\
znaczny - mikroorganizmy widoczne \\
już nieuzbrojonym okiem, w postaci \\
rzadkiego, puszystego nalotu i żółtawych \\
przebarwień na ok. 1/2 powierzchni
\end{tabular} \\
\hline
\end{tabular}

47 Oznaczenia w tabeli - dr Joanna Karbowska. 
Tab. 15. Oznaczenie drobnoustrojów (ciąg dalszy)

\begin{tabular}{|c|c|c|}
\hline Rodzaj kitu & $\begin{array}{l}\text { Rodzaj mikroorganizmów } \\
\text { i zmiany przez nie wywołane }\end{array}$ & Stopień rozwoju drobnoustrojów \\
\hline 4. BEVA Gesso-P & - Aspergillus & \begin{tabular}{l}
\multicolumn{1}{c}{+} \\
nieznaczny - pojedyncze kolonie \\
widoczne dopiero po dłuższym oglądzie, \\
najwyraźniej w powiększeniu
\end{tabular} \\
\hline 5. BEVA Gesso-V & $\begin{array}{l}\text { - Phoma, } \\
\text { - Alternaria, } \\
\text { - Penicillium, } \\
\text { - zarodniki jak ziarna ryżu (Acremonium ?), } \\
\text { - czarne kuliste spory o } \phi 4-6 \mu \mathrm{m}\end{array}$ & \begin{tabular}{l}
\multicolumn{1}{c}{+++} \\
znaczny - mikroorganizmy widoczne \\
nieuzbrojonym okiem w postaci szarego \\
i czarnego, puszystego nalotu
\end{tabular} \\
\hline 6. „Wiedeński” & - Aspergillus & $\begin{array}{l}\text { niewielki - słabo widoczny puszysty } \\
\text { nalot na ok. 1/4 powierzchni, najlepiej } \\
\text { w powiększeniu }\end{array}$ \\
\hline $\begin{array}{l}\text { 7. Klejowo- } \\
\text {-kredowy }\end{array}$ & $\begin{array}{l}\text { - Penicillium, } \\
\text { - Aspergillus, } \\
\text { - ciemne strzepki z czarnymi zgrubieniami } \\
\text { w formie kulistych tworów o } \phi 9,5 \mu \mathrm{m}\end{array}$ & $\begin{array}{l}\qquad++++ \\
\text { bardzo obfity - całą pożółkła powierzchnię } \\
\text { próbek porasta puszysty szary nalot oraz } \\
\text { gęsta siatka czarnej grzybni }\end{array}$ \\
\hline
\end{tabular}

\section{Badania odporności materiałów do uzupełniania ubytków zaprawy na starzenie w skrajnych warunkach temperatury i wilgotności powietrza}

Badania opisane w punktach 4.1-4.4 wykonano w szafie klimatycznej ze zmienną temperatura i wilgotnością VEB Feutron (Niemcy) (I etap) oraz w komorze wilgotnościowej z folii (II etap). Warunki badań były identyczne dla wszystkich wariantów próbek ${ }^{48}$.

\section{I etap:}

W szafie klimatycznej 3626\11 VEB Feutron (Niemcy), nr fab. 014\90. Założeniem było, aby cykl starzeniowy odpowiadał warunkom muzealnym, tj. charakteryzował się wysokimi temperaturami i niskimi wilgotnościami. Zakres temperatur zawierał się w przedziale $25-39^{\circ} \mathrm{C}$, a zakres wilgotności

48 Warunki badań zostały ustalone na podstawie konsultacji z prof. dr Bogumiłą Rouba. 
względnych między 20 a 40\%. Czas pozostawania próbek w tych warunkach wynosił dwa i pół miesiąca. Po upływie tego czasu wyjęto je z szafy klimatycznej, poddano analizie wizualnej, opisano zmiany, po czym poddano dalszemu starzeniu (II etap).

\section{II etap:}

Drugi etap w założeniach powinien odpowiadać warunkom, jakie najczęściej panują w starych kościołach - a więc wysokim wilgotnościom i stosunkowo niskim temperaturom. Na drugi cykl starzeniowy próbki umieszczono w komorze wilgotnościowej wykonanej z folii, gdzie temperatura wynosiła około $20-24^{\circ} \mathrm{C}$, natomiast wilgotność w pierwszych dwóch tygodniach $64-70 \%$, przez dwa następne miesiące wahała się między 71 a 86\% (wyższe wilgotności były osiagane przez szczelne zamykanie komory, a niższe przez otwieranie jej na 6-8 godzin dziennie). Próbki były umieszczone w komorze wilgotnościowej przez dwa i pół miesiąca.

\subsection{Badanie odporności kitów założonych na nowym płótnie na starzenie w skrajnych warunkach}

Przygotowanie próbek do badań i warunki ich przechowywania:

Nowe płótno lniane zdekatyzowano i po wyprasowaniu przeklejono 2\% metylocelulozą. Po napięciu płótna na cienką, sztywną płyte pilśniową nanoszono próbki kitów o jednakowej grubości na uprzednio wyznaczone miejsca. Do tego celu wykorzystano szablon z blachy miedzianej o grubości 0,8 mm, w którym wycięto prostokątny otwór o wymiarach $70 \mathrm{~mm} \times 30 \mathrm{~mm}$. Szablon przymocowywano taśmami do podłoża i szpachlą wypełniano otwór kitem, a w przypadku stwierdzenia zmian objętości na skutek skurczu materiału w trakcie wysychania uzupełniano kit do żądanej grubości. Próbki sezonowano w warunkach laboratoryjnych (temp. ok. $20^{\circ} \mathrm{C}$, RH 40-45\%) przez cztery tygodnie, po czym wyszlifowano ich powierzchnie, zaizolowano błyszczącym akrylowym werniksem retuszerskim i pozostawiono w tych samych warunkach przez tydzień. Następnie na 2/3 powierzchni każdej próbki zwilżonej żólcią wołową naniesiono po dwie warstwy farby akwarelowej w kolorze żółtej ochry, imitującej retusz malarski. Po wyschnięciu retusze zawerniksowano dwukrotnie półmatowym akrylowym werniksem końcowym. Dla każdego kitu przygotowano próbki w dwóch powtórzeniach. Tak przygotowane 
płótno z próbkami zdjęto z pomocniczej płyty i napięto na ruchome krosna malarskie o wymiarach $40 \mathrm{~cm} \times 30 \mathrm{~cm}$ i poddano badaniom.

Omówienie wyników badań:

Przez cały czas trwania badań i po ich zakończeniu nie stwierdzono istotnych zmian w wyglądzie próbek kitów, a także płótna - poza wyraźnym obwiśnięciem płótna na krosnach podczas przebywania w szafie klimatycznej, gdzie panowały wysokie temperatury i niskie wilgotności. Sytuacja ta uległa zmianie po umieszczeniu próbek w komorze wilgotnościowej z wysokimi wilgotnościami - płótno uległo ponownemu naprężeniu. Po zakończeniu badań stwierdzono na powierzchni jednej z dwóch próbek kitu nr 2 - Italstucco obecność kilku drobnych, cienkich spękań biegnących od krawędzi próbki ku jej środkowi (il. 15-16).

\subsection{Badanie odporności kitów założonych na starym płótnie dublażowym na starzenie w skrajnych warunkach}

Przygotowanie próbek do badań i warunki ich przechowywania:

Stare płótno dublażowe kilkakrotnie zalewano wrzącą woda, aby pozbawić je pozostałości spoiwa dublażowego i zanieczyszczeń. Wyschnięte i wyprasowane płótno przeklejono 2\% metylocelulozą. Dalszy ciąg przygotowania i przechowywania próbek identyczny jak w punktach 4 i 4.1 . Omówienie wyników badań:

W trakcie trwania badań po wyjęciu próbek z szafy klimatycznej i komory wilgotnościowej nie stwierdzono wystąpienia jakichkolwiek zmian w wyglądzie próbek i płótna (poza nieznacznym obwiśnięciem w I etapie, a w II ponownym naprężeniem płótna - podobnie jak w punkcie 4.1).

\subsection{Badanie odporności kitów założonych na płótnie przesyconym masą woskowo-żywiczną na starzenie w skrajnych warunkach}

Przygotowanie próbek do badań i warunki ich przechowywania:

Nadmiary masy woskowo-żywicznej wyekstrahowano z płótna lnianego, rozgrzewając ją żelazkiem i wtapiając w bibuły filtracyjne. Od chwili napięcia 
płótna na pomocniczą płytę dalszy ciąg przygotowania i przechowywania próbek identyczny jak w punktach 4, 4.1 i 4.2.

Omówienie wyników badań:

Próbki na przewoskowanym starym płótnie dublażowym zachowały się podobnie, jak próbki kitów badane na dwóch innych rodzajach płócien. Nie stwierdzono żadnych zmian w ich wyglądzie i stanie zachowania.

Podsumowanie badań i wnioski:

Przeprowadzone analizy odporności kitów na starzenie w skrajnych warunkach temperatury i wilgotności powietrza dały wyniki, które można, co prawda, uznać za zadowalające, jednakże należy pamiętać, że czas trwania badań musiał być z przyczyn obiektywnych ograniczony, a także że ich przebieg z powodów niezależnych miał nieco inny charakter, niż początkowo zakładano. Prawie wszystkie kity (z jednym wyjątkiem) nie zmieniły się w trakcie badań: nie stwierdzono wystapienia spękań, deformacji, pudrowania się powierzchni kitów, łuszczenia, pociemnienia lub zmiany barwy, zmatowienia lub nadmiernego wybłyszczenia. Także przyczepność kitów do płócien nie zmieniła się zauważalnie: nie stwierdzono unoszenia się krawędzi próbek czy ich odstawania od podłoża. Należy zaznaczyć, że badane kity są materiałami profesjonalnymi i w takim przypadku warunki starzenia musiałyby być bardzo drastyczne, aby spowodować ich zniszczenie.

Jedynym kitem, na którym pojawiły się drobne, cienkie spękania biegnące od krawędzi próbki ku jej środkowi, był kit nr 2 - Italstucco założony na nowym płótnie lnianym. Druga próbka omawianego kitu nie spękała, trudno wobec tego jednoznacznie stwierdzić, czy przyczyna tego stanu leży w pracy płótna i jego wpływie na kit (trzeba zwrócić uwagę na fakt, że podłożem próbki było nowe, żywe płótno, które bardzo intensywnie reaguje zmianami wymiarów liniowych na wahania wilgotności), czy też należy jej szukać po stronie ewentualnych błędów popełnionych w trakcie przygotowywania próbek lub późniejszego obchodzenia się z nimi (nie można wykluczyć nieznacznego urazu mechanicznego podczas ich wyjmowania i przenoszenia, który osłabił odporność mechaniczną próbek). Niemniej jednak należałoby zwrócić baczną uwagę na wymieniony kit, gdyż wynik badania wskazuje, że niektóre jego właściwości mogą być niewystarczające, aby stosować go jako materiał do uzupełniania ubytków zapraw w obrazach na płótnie. 
W celu pełnego sprawdzenia odporności kitów na ruchy pracującego podłoża płóciennego należałoby kontynuować badania jeszcze przez jakiś czas - najlepiej w szafieklimatycznej, gdzie możliwe byłoby zaprogramowanie zmian temperatury i wilgotności, przebiegających z dużą częstotliwością.

\subsection{Badanie odporności kitów założonych w ubytkach zaprawy destruktu starego obrazu na starzenie w skrajnych warunkach}

Badania wykonano w szafie klimatycznej VEB Feutron (Niemcy) ze zmienną temperaturą i wilgotnością (I etap) oraz w komorze wilgotnościowej z folii (II etap).

Przygotowanie próbek do badań i warunki ich przechowywania:

Obraz, którego destrukt posłużył jako podłoże dla badanych kitów, pochodził prawdopodobnie z XVII wieku, przedstawiał portret i został namalowany w technice olejnej wielowarstwowej na czerwonej emulsyjnej zaprawie. W przeszłości został poddany zabiegowi dublażu lub konsolidacji z użyciem masy woskowo-żywicznej przesycającej płótno, której nadmiary przed wykonaniem próbek wyekstrahowano. Wybrano fragmenty destruktu obrazu, wydzielono z nich siedem prostokątnych poletek o zbliżonym stopniu uszkodzenia zaprawy. Wykonano także niezbędne reperacje lokalne płótna, aby odtworzyć podłoże dla kitów. Następnie przystąpiono do uzupełniania ubytków zaprawy, przyporządkowując oddzielny, wydzielony obszar każdemu z kitów. Kity nakładano z pewnym nadmiarem, a po ich wyschnięciu opracowywano ich powierzchnie na sucho (skalpelem i papierem ściernym o drobnej gradacji) oraz na mokro (korkiem zwilżonym wodą lub benzyną lakową w przypadku kitów nr 4 i nr 5), wyrównując powierzchnie wypełnień z otaczająca je oryginalną warstwą malarską i pozostawiając je tylko w ubytkach. Tak przygotowane próbki pozostawiono przez trzy tygodnie w warunkach laboratoryjnych, po czym na wszystkie powierzchnie lica naniesiono werniks retuszerski damarowy i pozostawiono jeszcze na tydzień. Po tym czasie próbki poddano starzeniu pod wpływem skrajnych warunków temperatury i wilgotności. W szafie i komorze zostały one umieszczone na podpórkach w taki sposób, aby jak największa powierzchnia lica i odwrocia pozostawała nieosłonięta, a tym samym mogła reagować na zmiany warunków. 
Omówienie wyników badań:

Już w trakcie uzupełniania ubytków stwierdzono pewne różnice w zachowywaniu się kitów. Na większości uzupełnień pojawiły się spękania, których nie udało się wyeliminować mimo kilkakrotnego usuwania i ponownego zakładania kitów. Także w trakcie opracowywania powierzchni kitów i przenoszenia próbek dość łatwo można było spowodować popękanie uzupełnień (problemy takie nie występowały w przypadku próbek aplikowanych nawet w większych grubościach na płótna przygotowywane do innych badań). Tylko kity nr 4 i nr 5 - BEVA Gesso-P i BEVA Gesso- $V$ nie popękały założone w ubytki destruktu - zarówno podczas przygotowywania, jak i w trakcie badań. Na pozostałych odnotowano występowanie większej (nr 7 - zwłaszcza na dużych wypełnieniach) lub mniejszej ilości spękań (nr l - dwa pęknięcia, nr 2 - kilka dłuższych pęnięć, nr 3 - kilka drobnych spękań, nr 6 - jedno peknięcie) jeszcze przed wstawieniem ich do szafy i komory. Należy także wspomnieć, że zabieg izolowania kitów werniksem retuszerskim przysparzał w kilku przypadkach sporo problemów. Kilkakrotnego powtarzania zabiegu wymagały bardzo chłonne kity nr 1 i nr 2 oraz nieco mniej od nich chłonny kit nr 3. Na ich powierzchniach były widoczne miejsca o większej i mniejszej chłonności - w postaci matowych, niedających się wyrównać, i błyszczących partii. Dość dobrze i równomiernie udało się zawerniksować kity nr 6 i nr 7 , a zupełnie bez problemów kity nr 4 i nr 5, które uzyskiwały jednorodne błyszczenie już po jednorazowym rozprowadzeniu werniksu. W przypadku dwóch ostatnich kitów wskazane jest szybkie i sprawne nanoszenie werniksu lub stosowanie żywicy rozpuszczanej w innym niż benzyna lakowa, olejek terpentynowy lub węglowodory aromatyczne rozpuszczalniku, aby uniknąć reaktywowania (i zniszczenia) opracowanej powierzchni kitu.

Po pięciu miesiącach badań nie stwierdzono wyraźnego pogorszenia się kondycji większości kitów. Najlepiej spisały się kity nr 4 i nr 5 - BEVA Gesso-P i BEVA Gesso-V, które pozostały niemal całkowicie niezmienione od momentu założenia ich w ubytki warstw malarskich. Jedyną zauważoną zmianą jest nieznaczne zmatowienie werniksu retuszerskiego i pojawienie się słabo widocznych zacieków o żółtawych brzegach na powierzchni obu materiałów. Fakt ten stwierdzono po I etapie badań - prawdopodobnie powstały one w wyniku działania na próbki wysokich temperatur - trudno jednak jednoznacznie określić, czy zareagował w ten sposób werniks, „wypacając się”, czy 
też kity, wrażliwe na podwyższoną temperature - ich powierzchnia wydaje się nienaruszona. Na kicie nr 7 - klejowo-kredowym modyfikowanym, mającym najwięcej spękań powstałych podczas wysychania, zauważono silniejsze zarysowanie się pęknięć (głównie na dużych ubytkach) i pojawienie się kilku nowych niewielkich rys. Brzegi większych peknięć wydają się nieznacznie uniesione. Jednakże przyczepność do podłoża i krawędzi ubytków nie pogorszyła się, a inne zmiany nie zostały stwierdzone. Dwa nieznaczne pęknięcia (bardzo słabo widoczne delikatne rysy) pojawiły się też na wypełnieniach wykonanych z kitu nr 2 - Italstucco.

Pozostałe kity, które przejawiały tendencje do pękania na podłożu destruktu przed rozpoczęciem właściwych badań, nie wykazały postępujących zniszczeń. Nie stwierdzono zwiększonej ilości spękań w stosunku do stanu pierwotnego ani też wyraźnych zmian w wyglądzie już istniejących. Brzegi spękań nie uniosły się ani nie rozeszły, przyczepność kitów do podłoża nie uległa wyraźnym zmianom na gorsze; nie stwierdzono dezintegracji, łuszczenia się, odpadania kitów od płótna. Także ich przyczepność do brzegów ubytków w żadnym przypadku nie została naruszona. Nie zauważono deformacji płótna spowodowanych obecnością kitów (jedynie delikatne, nietrwałe wygięcie próbek wywołane punktowym podparciem i reakcją płótna na zmienne warunki). Na znacznej powierzchni kitu nr 2 - Italstucco - stwierdzono występowanie partii zmatowiałego werniksu.

Przyczyny tak nieznacznych zmian w materiałach wypełniających ubytki można szukać w charakterze i kondycji starego podłoża, które będąc już prawdopodobnie martwe, zostało przesycone masą woskowo-żywiczną, co jeszcze dodatkowo spowalnia reakcje płótna na zmiany wilgotności i temperatury (il. 17-20). Pękanie kitów po założeniu ich w ubytki, praktycznie już w chwili wysychania, jest efektem trudnym do interpretacji, zważywszy, że podłoże próbek jako mało wrażliwe na wilgoć i niereagujące gwałtownie nie powinno powodować naprężeń w wysychającym kicie. Obserwacje poczynione w trakcie przygotowywania próbek do wszystkich poprzednich badań, gdzie kity były aplikowane w różnych grubościach i na różne rodzaje podłoży (przeklejone i przewoskowane płótna, szkło), wskazują na to, że zastosowanie mało elastycznego lub sztywnego podłoża nie skutkuje powstawaniem spękań w warstwach kitów. Jednakże w przypadku poprzednio przygotowywanych próbek płótna były napinane na pomocniczą płyte pilśniową, co pozwalało na 
równomierne rozłożenie naprężeń wywołanych przez miejscowe zwilżenie płótna w wyniku nałożenia kitu i na uniknięcie deformacji płótna lub pękania kitów. W innych sytuacjach (szkiełka przedmiotowe) niezwilżalne podłoże nawet $\mathrm{w}$ minimalnym stopniu nie reagowało zmianami podczas nanoszenia kitów, nie powodując naprężeń na granicy podłoże-kit. Wobec powyższego można przypuszczać, że pękanie kitów na bazie wodoroztwarzalnego spoiwa we fragmentach destruktu obrazu w jakiejś mierze zostało spowodowane nieustabilizowaniem próbek na podłożu pomocniczym. Przyczyny pękania kitów można też upatrywać w niedostatecznym przylgnięciu ich do podobrazia, o którym to przypadku wzmiankuje Slansky ${ }^{49}$. Autor twierdzi, że substancje wodoodporne obecne w kitowanej powierzchni utrudniają zwilżanie płótna przez wodę z kitu, na skutek czego na wyschniętych powierzchniach powstaja peknięcia. W wyżej opisanych badaniach, gdzie jako podłoże zastosowano fragmenty destruktu obrazu, płótno było przesycone masą woskowo-żywiczną, której nadmiary, co prawda, ekstrahowano, jednakże zabieg ten nie gwarantuje całkowitego usunięcia substancji przesycającej włókna. Pozostałości masy mogły w tym przypadku przeszkadzać w dobrym przylgnięciu kitów do płótna i być przyczyną powstawania pęknięć.

\section{Badania odwracalności kitów}

\subsection{Badanie odwracalności kitów przechowywanych w skrajnych warunkach temperatury i wilgotności w szafie klimatycznej i komorze wilgotnościowej}

Przygotowanie próbek do badań i warunki ich przechowywania:

Do badań odwracalności wykorzystano próbki przygotowane w sposób opisany w punktach 4.1 i 4.2 (tam też warunki przechowywania próbek), przeprowadzono je po badaniach odporności na starzenie w szafie klimatycznej i komorze wilgotnościowej, trwających łącznie pięć miesięcy. Po upływie tego czasu przystąpiono do wykonania testów na usuwanie kitów z podłoża

49 B. Slansky, Technika malarstwa, t. 2: Badanie, s. 239. 
płóciennego, a następnie z wypełnionych ubytków we fragmentach destruktu obrazu.

Przebieg badań:

Do wstępnych testów przeznaczono po jednej z dwóch próbek kitów o grubości $0,8 \mathrm{~mm}$, naniesionych na stare płótno dublażowe, ze względu na, bliską zabytkowym obrazom, zmniejszoną wytrzymałość podłoża. Jako pierwsze sprawdzono mechaniczne metody usuwania kitów z płótna, polegające na zeskrobywaniu, nacinaniu, rozkruszaniu, podważaniu i odrywaniu rozdrobnionych kitów od podłoża za pomocą skalpela oraz mikrowiertarki Proxxon z wymiennymi końcówkami. W dalszej kolejności przetestowano metody chemiczne, łącznie z metodami mechanicznymi; powierzchnie kitów poddawano działaniu rozpuszczalników przez zastosowanie nasączonych nimi, niewielkich ligninowych kompresów. Kompresy zabezpieczano folią przed odparowywaniem rozpuszczalników i pozostawiano na powierzchni kitów przez około piętnaście minut. W razie konieczności, gdy stwierdzano oddziaływanie rozpuszczalnika na konkretny kit, ale w stopniu niepozwalającym na rozmiękczenie w całej grubości, przedłużano czas kontaktu na kolejny kwadrans. Następnie podejmowano próby mechanicznego usunięcia kitu z podłoża za pomocą skalpela. Sprawdzono również możliwości rozmiękczenia lub całkowitego usunięcia kitów przez poddanie ich działaniu podwyższonej temperatury. W tym celu posłużono się kauterem z regulacją temperatury. Po wykonaniu wszystkich prób i wytypowaniu tych metod, które dały najlepsze rezultaty w stosunku do poszczególnych kitów, zastosowano je do usuwania uzupełnień ubytków założonych na fragmentach destruktu obrazu. Z każdej próbki usunięto około 1/3 wykonanych uprzednio wypełnień. Wyniki badań:

Podczas badań zwracano uwagę na łatwość rozkruszania (twardość lub miękkość) kitów, ich przyczepność do podłoża płóciennego, zdolność spulchniania lub rozmiękczania powierzchni kitów przez wode, rozpuszczalniki lub rozgrzany do temperatury około $75^{\circ} \mathrm{C}$ kauter, a w przypadku fragmentów destruktu obrazu - dodatkowo także na przyczepność do sąsiadujących z kitami warstw oryginalnych i możliwości usunięcia kitów bez narażania warstw malarskich i płótna na uszkodzenie. Wyniki badań i obserwacji przedstawiono w poniższej tabeli. 
Tab. 16. Badania odwracalności kitów z zastosowaniem metod mechanicznych i chemicznych

\begin{tabular}{|l|c|c|c|c|c|c|c|c|}
\hline \multicolumn{1}{|c|}{ Rodzaj kitu } & Skalpel & $\begin{array}{c}\text { Mikro- } \\
\text { wiertarka }\end{array}$ & $\begin{array}{c}\text { Woda } \\
\text { destylo- } \\
\text { wana }\end{array}$ & $\begin{array}{c}\text { Benzyna } \\
\text { lakowa }\end{array}$ & $\begin{array}{c}\text { Alkohol } \\
\text { etylowy }\end{array}$ & $\begin{array}{c}\text { Woda } \\
\text { amonia- } \\
\text { kalna }\end{array}$ & Ksylen & Kauter \\
\hline 1. Tikkurila & + & ++ & ++ & ++ & $\begin{array}{c}30 \mathrm{~min} \\
+++\end{array}$ & $\begin{array}{c}30 \mathrm{~min} \\
+++\end{array}$ & ++ & b.z. \\
\hline 2. Italstucco & ++ & +++ & +++ & +++ & +++ & +++ & +++ & b.z. \\
\hline 3. Modostuc & ++ & +++ & +++ & b.z. & +++ & +++ & +++ & b.z. \\
\hline 4. BEVA Gesso-P & +++ & ++ & b.z. & ++++ & b.z. & b.z. & ++++ & ++++ \\
\hline 5. BEVA Gesso-V & +++ & ++ & b.z. & ++++ & b.z. & b.z. & ++++ & ++++ \\
\hline 6. „Wiedeński” & + & ++ & $\begin{array}{c}30 \text { min } \\
++\end{array}$ & b.z. & $\begin{array}{c}30 \text { min } \\
++\end{array}$ & $\begin{array}{c}30 \text { min } \\
+++\end{array}$ & b.z. & b.z. \\
\hline $\begin{array}{l}\text { 7. Klejowo- } \\
\text {-kredowy }\end{array}$ & + & ++ & +++ & b.z. & $\begin{array}{c}30 \text { min } \\
++\end{array}$ & $\begin{array}{c}30 \text { min } \\
+++\end{array}$ & b.z. & b.z. \\
\hline
\end{tabular}

\section{Objaśnienia:}

$+\quad$ trudno usuwalny twardy kit,

$++\quad$ kit usuwalny bez większego trudu,

++ kit latwo usuwalny,

++++ kit bardzo łatwo usuwalny,

b.z. bez zmian - środek nie powoduje wyraźnego rozmięczenia kitu.

Omówienie wyników badań i wnioski:

Przeprowadzone badania ukazały różnice w skuteczności metod zastosowanych do usuwania poszczególnych rodzajów kitów z płótna. Generalnie wszystkie kity można ocenić jako odwracalne, jednakże usunięcie ich wymaga użycia właściwej metody i środka. W odniesieniu do metod mechanicznych stwierdzono, że najłatwiej usuwalne za pomocą skalpela okazały się kity nr 4 i nr 5. Także stosunkowo łatwo dawały się rozkruszać i usuwać kity nr 2 i nr 3. Najtrudniejsze do usunięcia w ten sposób były bardzo twarde kity nr 1 , nr 6 i nr 7, które wymagały użycia znacznej siły, zarówno do rozkruszenia, jak i do oddzielenia ich od podłoża. W przypadku tych trzech materiałów znacznie wygodniejsze i bezpieczniejsze było użycie mikrowiertarki, która dawała szerokie możliwości ustawienia obrotów odpowiednio dobranej końcówki. W ten sposób rozdrobnienie nawet twardych materiałów nie nastręczało żadnych problemów, pozwalając na pełne kontrolowanie i stopniowanie prędkości, nacisku narzędzia oraz na natychmiastowe przerwanie pracy w razie potrzeby. Metoda ta okazała się nieodpowiednia w stosunku do kitów 
nr 4 i 5 - BEVA Gesso-P i BEVA Gesso- $V$, które pod wpływem wytworzonego ciepła topiły się i oklejały końcówkę narzędzia. Także kompresy wodne, alkoholowe i amoniakalne nie miały wpływu na wyjściowy stopień twardości tych dwóch kitów. Jednakże zastosowanie kompresów z benzyną lakową, a także z ksylenem reaktywuje i całkowicie rozmiękcza wymienione materiały, czyniąc je tak miękkimi i plastycznymi, jak były w momencie wyjęcia ich z pojemnika i zakładania w ubytki. Efekt rozmiękczenia jest też uzyskiwany przez miejscowe ogrzewanie kitu za pomocą końcówki kautera.

Wodne kompresy pozwalały na rozmiękczenie i łatwiejsze usunięcie kitów nr 2, nr 3 i nr 7, a po 30 minutach także kitów nr 1 i nr 6. Podobnie kompresy z alkoholem etylowym ułatwiają usunięcie kitów nr 2 i nr 3, a po 30 minutach w podobnym stopniu rozmiękczają kit nr 1 oraz nieco słabiej kity nr 6 i nr 7. Kompresy amoniakalne pozwalają też na łatwiejsze usunięcie kitów nr 2 i nr 3, a po przedłużonym czasie działania także kitów nr 1, nr 7 i nr 6. Zastosowanie kompresów z benzyną lakową nie wpływa na zmiękczenie kitów nr 3, nr 6 i nr 7, nieznacznie zmiękcza kity nr 1 i nr 2, natomiast kompresy z ksylenem nie powodują żadnych zmian w twardości kitów nr 6 i nr 7 , słabo zmiękczają kit nr 1 oraz nieco bardziej kity nr 2 inr 3. Rozgrzanie kitów za pomocą kautera skutkuje tylko we wzmiankowanym już przypadku kitów nr 4 i nr 5. Stosując tę metode, nie stwierdzono zauważalnego wpływu na pozostałe materiały.

Oceniając skuteczność przeprowadzonych testów na rozmiękczanie oraz związaną z nim łatwość usuwania kitów z podłoża płóciennego, wytypowano dla poszczególnych wypełnień najbardziej efektywne metody i środki. Przedstawia się to w następujący sposób:

1. Tikkurila - kompres $\mathrm{z}$ alkoholem etylowym oraz z amoniakiem (30 min).

2. Italstucco - kompresy wodne i z wszystkimi pozostałymi rozpuszczalnikami (15 min).

3. Modostuc - kompresy wodne i z pozostałymi rozpuszczalnikami poza benzyną lakowa.

4. BEVA Gesso-P - kompresy z benzyną lakową oraz z ksylenem, rozgrzanie kauterem, skalpel.

5. BEVA Gesso- $V$ - kompresy z benzyną lakową oraz z ksylenem, rozgrzanie kauterem, skalpel. 
6. Kit emulsyjny „wiedeński” - kompres amoniakalny (po 15 min), kompresy wodny i alkoholowy (po $30 \mathrm{~min}$ ).

7. Kit klejowo-kredowy modyfikowany - kompres wodny (po 15 min), kompres amoniakalny (po $30 \mathrm{~min}$ ).

Należy zaznaczyć, że zagadnienia odwracalności kitów nie można rozpatrywać w oderwaniu od substancji sąsiadującej z materiałem wypełniającym ubytek. Dobór środka i metody musi być uzależniony przede wszystkim od kondycji i wrażliwości warstw oryginalnych, tak aby nie powodować ich uszkodzenia. Teoretycznie istnieje możliwość zastosowania szerokiej gamy rozpuszczalników, które pozwoliłyby na rozmiękczenie i usunięcie bardzo twardych materiałów wtórnych z obrazu. Nie może to jednak przebiegać w sposób, który naraziłby substancję zabytkową na zniszczenie lub uszkodzenie. Najlepiej jest, gdy istnieje możliwość usunięcia wypełnienia kilkoma metodami, co pozwala na dokonanie wyboru tej najwłaściwszej, najmniej inwazyjnej dla konkretnego, indywidualnego przypadku.

\section{Podsumowanie wyników badań}

Przeprowadzone badania miały na celu poznanie i ukazanie właściwości fizykochemicznych i mikrobiologicznych niektórych produktów firmowych oraz zestawienie ich z pogłębioną charakterystyką dwóch kitów sporządzanych według receptur, a także określenie ich przydatności do uzupełniania ubytków zapraw w malowidłach na płótnie przez zbadanie ich odporności na działanie skrajnych warunków temperatury i wilgotności względnej powietrza oraz odwracalności po kilku miesiącach przebywania materiałów w wyżej wymienionych warunkach. Zestawione poniżej wyniki wszystkich badań pozwalają na całościowy ogląd właściwości poszczególnych kitów, na ostateczną ocenę i próbę wytypowania najlepszych materiałów.

\subsection{Kit nr 1 - Tikkurila, Spakelli Pukitti (Tikkurila, Finlandia)}

Badania składu chemicznego preparatu pozwoliły na zidentyfikowanie podstawowych jego składników, tj. spoiwa pochodzenia organicznego - prawdopodobnie z grupy polimerów akrylowych - oraz wypełniaczy: weglanu 
wapnia i przypuszczalnie weglanu magnezu (interpretacja niepewna). Dodatki użyte w niewielkich ilościach nie zostały zidentyfikowane.

Świeży, wyjęty z puszki preparat jest bardzo gęstą, zwartą pastą o konsystencji przypominającej chałwe, charakterystycznym zapachu amoniaku i śnieżnobiałej barwie. Barwienie świeżej masy jest możliwe dzięki użyciu suchych pigmentów lub farb akrylowych. Kit może być aplikowany za pomocą szpachelek, skalpeli i łopatek, a po rozcieńczeniu wodą (które z powodu konsystencji może okazać się niezbędne) do płynnej postaci także pędzlem. Po częściowym podeschnięciu możliwe jest odciskanie faktury na powierzchni kitu za pomoca negatywowych form z tworzyw sztucznych. Kit jest materiałem plastycznym, dającym możliwości bardzo wyraźnego odwzorowania zarówno subtelnej faktury, np. splotu płótna, duktu pędzla, jak i nieco mocniejszego opracowania malarskiego. Po całkowitym wyschnięciu warstwy o grubości $0,5 \mathrm{~mm}$, trwającym około $160 \mathrm{~min}$, powierzchnia kitu jest gładka, matowa, z niewielką ilością maleńkich dziurek po pecherzykach powietrza. Po wyschnięciu wypełnienie utworzone przez kit jest bardzo twarde. Wyrównywanie powierzchni jest w jego przypadku najłatwiejsze na mokro - korkiem, drewnem balsa zwilżonymi wodą bądź acetonem, ewentualnie na sucho przez skrobanie ostrym skalpelem lub szlifowanie papierem ściernym.

Kit aplikowany w warstwach o grubości powyżej 1,0 mm podlega po wyschnięciu znacznemu skurczowi, z towarzyszącymi mu od grubości 1,5 mm spękaniami w całej masie, które wraz ze wzrostem grubości są głębsze i bardziej rozległe. Rozcieńczenie kitu wodą ułatwiające jego nanoszenie sprawia, że skurcz i spękania są znacznie poważniejsze. Z tego powodu rozcieńczony kit trzeba aplikować w niewielkich grubościach, jeśli to konieczne - warstwowo.

Odczyn pH preparatu przed związaniem i po wyschnięciu jest słabo zasadowy i wynosi odpowiednio 8,2 i 8,0 - jest więc bezpieczny dla podłoża płóciennego. Przyczepność wyschniętego kitu do nowego, przeklejonego metylocelulozą płótna jest bardzo dobra, a do płótna przesyconego masą woskowo-żywiczną dobra. Wartości liczbowe określające siłę potrzebną do naderwania układu kit-płótno wynoszą odpowiednio dla poszczególnych podłoży: 7,81 i 4,88 daN/cm². Mechaniczne oderwanie kitu od płótna za pomocą skalpela przebiega z pewnym trudem i wymaga użycia znacznej siły. 
Elastyczność kitów przechowywanych w warunkach laboratoryjnych jest dość dobra. Przesuszanie kitu nie wpływa na zmniejszenie się elastyczności, natomiast nawilżanie w warunkach podwyższonej wilgotności względnej powietrza nieco poprawia tę właściwość. Zdolność pochłaniania pary wodnej przez kit jest bardzo wysoka. Jego higroskopijność wynosi blisko 8,5\% i, mimo pozytywnego wpływu na elastyczność, w znacznym stopniu zmniejsza odporność mechaniczną wypełnienia. Chłonność i zwilżalność kitu są bardzo dobre - kropla wody naniesiona na wyszlifowaną, nieizolowaną powierzchnię rozlewa się szeroko i wsiąka w głąb kitu - a nawet zbyt duże. Także werniks retuszerski damarowy i akrylowy są wchłaniane w kit i trzeba nanieść wiele warstw, aby uzyskać błyszcząca, zaizolowaną powierzchnię. Warstwa werniksu w poważnym stopniu ogranicza chłonność i zwilżalność kitu przez wodne spoiwo retuszu. Drugą z tych właściwości zdecydowanie poprawia (nawet w stosunku do nieizolowanej powierzchni) zastosowanie żółci wołowej. Kropla wody wnika jednak tylko częściowo w głąb kitu, a częściowo odparowuje, mimo to przyczepność powłok malarskich akwarelowej i akrylowej do werniksowanej powierzchni kitu jest bardzo dobra.

Odporność kitu Tikkurila na atak mikroorganizmów można określić jako dość wysoką. Obecność drobnoustrojów stwierdzono pod mikroskopem po 2 miesiącach przebywania próbek w warunkach podwyższonej wilgotności względnej powietrza, a po upływie 6 miesięcy stopień rozwoju drobnoustrojów był nieznaczny, widoczny gołym okiem dopiero po dłuższym oglądzie.

Przechowywanie próbek kitu przez 5 miesięcy w skrajnych warunkach temperatury i wilgotności względnej powietrza nie spowodowało widocznych zmian w ich wyglądzie, kondycji i przyczepności do różnych rodzajów płócien. Analogicznie było w przypadku kitów założonych w ubytkach destruktu obrazu.

Odwracalność kitu, analizowana na próbkach poddanych badaniom odporności na starzenie w skrajnych warunkach temperatury i wilgotności względnej powietrza, jest osiagalna za pomocą kilku rozpuszczalników, umieszczonych w kompresach pozostawionych na powierzchni przez 15-30 minut. Najłatwiej jest usunać kit po zastosowaniu kompresów z alkoholu etylowego oraz z wody amoniakalnej. Nieco gorsze wyniki dały kompresy 
wodne, ksylenowe i z benzyną lakową. Bardzo trudne jest usunięcie kitu za pomocą skalpela z powodu znacznej twardości materiału i jego bardzo dobrej adhezji do płótna. Mechanicznie można go nieco łatwiej rozkruszyć za pomocą mikrowiertarki elektrycznej.

\subsection{Kit nr 2 - Italstucco (Ditta F. Follador - Mediolan, Włochy)}

Podstawowy skład kitu, określony na podstawie badań, jest następujący: spoiwem preparatu jest polioctan winylu, a wypełniaczami węglan wapnia i gips. Dodatki użyte w niewielkich ilościach nie zostały zidentyfikowane. Fabryczny preparat wyjęty z plastikowego pojemnika jest dość rzadką, jednorodną pastą o konsystencji gęstej śmietany i białym kolorze, pozbawioną zapachu. Możliwe jest rozcieńczanie kitu wodą, a także barwienie świeżego preparatu suchymi pigmentami lub farbami akrylowymi. Kit z łatwością może być aplikowany za pomocą szpachelek, skalpeli i lopatek, a po nieznacznym rozcieńczeniu wodą również pędzlem. Jest on materiałem plastycznym, który po częściowym podeschnięciu daje możliwość bardzo dobrego odwzorowania wszelkiego rodzaju faktury przez przyciskanie do jego powierzchni negatywowych form z tworzyw sztucznych. Wyschnięcie warstwy o grubości 0,5 mm trwa około 120-150 min, dając powierzchnię matową, gładką i równą. Wypełnienie wykonane z kitu jest po wyschnięciu bardzo miękkie, dające się bardzo łatwo wyrównywać, szlifować i wygładzać. Znaczny skurcz kitu, połączony z głębokimi wielokierunkowymi spekkaniami, występuje w warstwach o grubości powyżej 2,0 $\mathrm{mm}$. W warstwach od 0,8 do $1,5 \mathrm{~mm}$ skurcz jest nieznaczny i nie towarzyszą mu spękania.

Odczyn pH kitówki przed związaniem wynosi 7,5, a po wyschnięciu 8,0 - w obu przypadkach jest słabo zasadowy i jako taki nie stanowi zagrożenia dla podłoża płóciennego. Wyschnięty kit ma podobną, dobrą adhezje zarówno do nowego, przeklejonego metylocelulozą płótna, jak i do płótna przesyconego masą woskowo-żywiczną. Wartości liczbowe określające siłe potrzebną do naderwania układu kit-płótno wynoszą w tych przypadkach: 4,93 i 4,01 daN/ $\mathrm{cm}^{2}$. Podważanie i odrywanie kitu od płótna za pomocą skalpela nie jest zbyt trudne. Kity przechowywane w warunkach laboratoryjnych 
charakteryzują się dobrą elastycznością, którą nieco jeszcze polepsza nawilżanie w warunkach podwyższonej wilgotności względnej powietrza. Z kolei przesuszanie kitu wpływa dość znacznie na zmniejszenie się jego elastyczności. Jego higroskopijność wynosi około 5,5\% i już ta wartość wystarcza, aby poważnie zmniejszyć odporność mechaniczną sporządzonego wypełnienia. Wyszlifowany, nieizolowany kit charakteryzuje się bardzo dobrą chłonnością i zwilżalnością przez wodne spoiwo farby. W stosunku do werniksu retuszerskiego damarowego i akrylowego chłonność kitu jest zbyt duża - do tego stopnia, że bardzo trudno jest uzyskać równomierną izolację powierzchni werniks praktycznie nasyca wypełnienie. Zawerniksowany kit w ograniczonym stopniu chłonie wodne spoiwo retuszu i jest słabiej przez nie zwilżany, co można zniwelować przez użycie żółci wołowej. Wnikanie kropli wody jest i w tym przypadku tylko cześciowe. Przyczepność powłok uzupełnienia akwarelowego i akrylowego do werniksowanej powierzchni kitu jest bardzo dobra.

Odporność kitu Italstucco na atak drobnoustrojów jest dość wysoka. Pierwsze formy mikroorganizmów zaczęły być widoczne pod mikroskopem po 2 miesiącach przechowywania próbek w warunkach podwyższonej wilgotności względnej powietrza. Po upływie 6 miesięcy stopień rozwoju drobnoustrojów był nieznaczny, widoczny gołym okiem dopiero po dłuższej analizie.

Po pięciu miesiącach przechowywania próbek kitu w skrajnych warunkach temperatury i wilgotności względnej powietrza pojawiły się spękania na próbce naniesionej na nowe, żywe płótno, co może świadczyć o jego niskiej odporności na ruchy podobrazia spowodowane skokami wilgotności. Inne zmiany, zarówno w wyglądzie, jak i przyczepności do płócien, nie wystąpiły, podobnie jak w przypadku wypełnień założonych w ubytkach destruktu obrazu.

Odwracalność kitu, badana na próbkach starzonych w skrajnych warunkach temperatury i wilgotności względnej powietrza, nie stanowi większego problemu. Wszystkie przetestowane metody i środki okazały się skuteczne. Miękki i łatwy do usunięcia za pomocą skalpela kit, pod wpływem kompresów wodnych i rozpuszczalnikowych (benzyna lakowa, alkohol, amoniak, ksylen) jeszcze bardziej mięknie i bez trudu daje się usuwać. 


\subsection{Kit nr 3 - Modostuc (Plasvero S.p.A. - Vellezzo Bellini, Włochy)}

Informacje pochodzące od producenta, a także badania składu chemicznego preparatu pozwoliły na określenie składników: spoiwo - polioctan winylu, wypełniacze - węglan wapnia, siarczan baru, dodatki użyte w niewielkich ilościach: hydroksypropyloceluloza, nitrobenzen.

Świeży preparat po wyjęciu z plastikowego pojemnika jest nieco ciągliwą, gęstą pastą o konsystencji przypominającej surowe ciasto, charakterystycznym zapachu migdałów i białej barwie o ciepłym odcieniu. Suche pigmenty i farby akrylowe dają możliwość barwienia kitu w masie. Może on być łatwo aplikowany za pomocą szpachelek, skalpeli i łopatek, a po rozcieńczeniu wodą do płynnej postaci także pędzlem. Warstwa o grubości 0,5 mm wysycha około 120-150 min, pozostawiając matową, gładką i równą powierzchnię kitu, którą bez trudu można szlifować i wyrównywać. W częściowo wyschniętym kicie można łatwo odciskać faktury płótna, duktu pędzla czy charakterystycznego opracowania malarskiego za pomocą negatywowych form. Odwzorowanie faktury jest bardzo wierne i dokładne.

Warstwy kitu o grubości powyżej 1,5 mm wysychają ze znacznym skurczem oraz z towarzyszącymi mu spękaniami w całej masie. Rozcieńczenie kitu wodą może jeszcze pogłębić tę tendencje, toteż w tej postaci może być on nakładany jedynie w cieńszych warstwach.

Pod względem odczynu kit jest bezpieczny dla podłoża płóciennego zarówno przed związaniem, jak i po wyschnięciu - jest on słabo zasadowy i jego pH wynosi odpowiednio 8,1 i 7,9. Adhezja wyschniętego kitu do nowego, przeklejonego metylocelulozą płótna, jak również do płótna przesyconego masą woskowo-żywiczną jest dość dobra. Wartości liczbowe określające siłe potrzebną do naderwania układu kit-płótno wynoszą w pierwszym przypadku 3,79, a w drugim 3,63 daN/ $\mathrm{cm}^{2}$. Oderwanie kitu od płótna za pomocą skalpela przebiega stosunkowo łatwo i nie wymaga nadmiernego wysiłku. Elastyczność kitów przechowywanych w warunkach laboratoryjnych nie jest zbyt wysoka (można ją ocenić jako dostateczną). Przesuszanie kitu nie powoduje pogorszenia się elastyczności, natomiast nawilżanie w warunkach podwyższonej wilgotności względnej powietrza znacznie poprawia tę właściwość. Higroskopijność kitu wynosi niespełna 5\% i nie wpływa w znaczący 
sposób na osłabienie jego odporności mechanicznej. Chłonnośći zwilżalność wyszlifowanego, nieizolowanego kitu są stosunkowo dobre - kropla wody naniesiona na powierzchnię rozlewa się i wsiąka w głąb kitu, ale w tym przypadku trwa to ponad jedną godzinę. Wchłanianie werniksu retuszerskiego damarowego i akrylowego nie jest tak intensywne jak w przypadku dwóch pierwszych kitów. Niemniej jednak w celu utworzenia warstwy izolującej kit potrzebne jest kilkakrotne werniksowanie. Po zawerniksowaniu powierzchni chłonność i zwilżalność kitu przez wodne spoiwo retuszu są w znacznym stopniu ograniczone. Zastosowanie żółci wołowej zdecydowanie poprawia zwilżalność, ale wnikanie kropli wody w głąb kitu jest częściowe. Przyczepność powłok retuszu akwarelowego i akrylowego do jego werniksowanej powierzchni, podobnie jak w dwóch poprzednich przypadkach, jest bardzo dobra.

Odporność kitu Modostuc na atak mikroorganizmów nie jest zbyt wysoka, ale też nie najniższa - można ją określić jako średnią. Obecność drobnoustrojów stwierdzono pod mikroskopem po 2 miesiącach przebywania próbek w warunkach podwyższonej wilgotności względnej powietrza, ale po 4 miesiącach nieznaczne zmiany były już zauważalne nieuzbrojonym okiem, a po upływie 6 miesięcy wzrost drobnoustrojów był wyraźnie widoczny.

Poddawanie próbek kitu działaniu skrajnych warunków temperatury i wilgotności względnej powietrza, trwającemu 5 miesięcy, nie spowodowało widocznych zmian w ich wyglądzie, kondycji i przyczepności do różnych rodzajów płócien. W przypadku kitów założonych w ubytkach destruktu obrazu kilka drobnych peknięć, które pojawily się zaraz po wyschnięciu wypełnień, nie zmieniło się w żaden sposób - nie uległy one powiększeniu ani poszerzeniu czy też innym zmianom, związanym z przyczepnością do płótna i krawędzi ubytków.

Badania odwracalności kitu, uprzednio poddanego pięciomiesięcznemu starzeniu w skrajnych warunkach temperatury i wilgotności względnej powietrza, dowiodły, że istnieje szereg możliwości usuwania tego materiału. Niezbyt trudne jest mechaniczne usunięcie kitu za pomocą skalpela, a bardzo łatwe za pomocą mikrowiertarki. Rozmiękczenie wypełnienia, skutkujące jego łatwym usuwaniem, jest osiągalne dzięki użyciu kompresów wodnych, alkoholowych, amoniakalnych i ksylenowych (pozostawionych na powierzchni przez $15 \mathrm{~min}$ ). 


\subsection{Kit nr $4-B E V A ®$ Gesso-P i kit nr 5 \\ - BEVA®Gesso-V (CPC Conservators Products Company - USA)}

Dwa preparaty firmowe BEVA ${ }^{\circledR}$ Gesso-P i BEVA ${ }^{\circledR}$ Gesso- $V$, których spoiwem jest $B E V A$ 371, zostaną omówione razem ze względu na ich liczne podobieństwa. Różnice zostaną wyszczególnione.

Świeże, wyjęte z puszki preparaty są gęstymi, niezbyt zwartymi masami o „puszystej” konsystencji i zapachu toluenu. BEVA Gesso-P ma barwę jasnougrową, która po wyschnięciu jaśnieje do koloru rozbielonego ugru, natomiast barwa BEVA Gesso-V jest ciemniejsza - ma kolor ciemnego ugru, uzyskujący po wyschnięciu kolor jasnego ugru, i zawiera wypełniacz o wyraźnie widocznej granulacji. Barwienie świeżych kitów jest możliwe dzięki użyciu suchych pigmentów, rozcieńczanie za pomocą benzyny lakowej, ksylenu i toluenu. Kit może być aplikowany za pomocą szpachelek, skalpeli i łopatek, a także kautera. Uzyskanie gładkiej powierzchni jest łatwiejsze po zwilżeniu narzędzia benzyną lakową. Po wyschnięciu możliwe jest odciskanie faktury na powierzchni kitu za pomocą rozgrzanych negatywowych form z tworzyw sztucznych lub reliefowej stopki kautera. Kit BEVA Gesso-P jest materiałem dającym możliwości dość wyraźnego odwzorowania faktury splotu płótna i duktu pędzla. BEVA Gesso-V ma pod tym względem nieco gorsze właściwości. Po całkowitym wyschnięciu warstw każdego z kitów o grubości 0,5mm, trwającym około $50 \mathrm{~min}$, ich powierzchnia ma wygląd uzależniony w dużym stopniu od sposobu aplikowania: jest matowa, gładka lub chropowata i nieco porowata. Wypełnienia utworzone przez kity po wyschnięciu są miękkie. Wyrównywanie powierzchni jest w ich przypadku najłatwiejsze zwilżonym benzyną lakową korkiem lub drewnem balsa, ewentualnie na sucho przez ścinanie ostrym skalpelem. Szlifowanie papierem ściernym powoduje „wałkowanie" materiałów.

Kity mogą być jednorazowo aplikowane w warstwach o znacznych grubościach (w badaniach maksymalna grubość próbki wynosiła 3,0 mm), gdyż po wyschnięciu niemal nie ulegają skurczowi ani pękaniu.

Odczyn $\mathrm{pH}$ preparatów zarówno przed związaniem, jak i po wyschnięciu jest słabo zasadowy i wynosi: dla świeżego i związanego kitu BEVA Gesso-P 7,7; dla bardziej zasadowego BEVA Gesso-V - świeżego 8,5, a dla 
związanego 8,7 - obydwa są więc bezpieczne dla podłoża płóciennego. Przyczepność wyschniętych kitów do nowego, przeklejonego metylocelulozą płótna jest dobra, a do płótna przesyconego masą woskowo-żywiczną nieco słabsza. Wartości liczbowe określające siłę potrzebną do naderwania układu kit-płótno wynoszą w przypadku BEVA Gesso-P odpowiednio dla poszczególnych podłoży: 5,15 i 3,74 daN/ $\mathrm{cm}^{2}$, natomiast dla BEVA Gesso-V 5,42 i 4,71 daN/ $\mathrm{cm}^{2}$. Mechaniczne oderwanie kitów od płótna za pomoca skalpela nie rodzi większych problemów. BEVA Gesso-P dzięki znacznej kohezji i elastyczności może być odrywany płatkami. Elastyczność kitów we wszystkich warunkach jest bardzo dobra - nawet przesuszanie nie wpływa na zmniejszenie ich elastyczności. Kity pozwalają na wyginanie ich na walcach o bardzo małych średnicach, po czym, bez żadnych konsekwencji w postaci pekania czy oddzielania się od podłoży, wracają do pierwotnej formy.

Zdolność pochłaniania pary wodnej przez kity jest bardzo niska; w przypadku BEVA Gesso-P higroskopijność przekracza nieco 0,4\%, dla BEVA Gesso- $V$, mimo że jest czterokrotnie wyższa, wynosi jedynie 1,8\%. Także chłonność i zwilżalność kitów przez wodne spoiwo farb są niewielkie - kropla wody naniesiona zarówno na nieizolowane, jak i pokryte werniksem retuszerskim powierzchnie nie rozlewa się wcale lub tylko nieznacznie i nie wsiaka w głąb kitu. W jednym i drugim przypadku krople wody pozostaja w niezmienionej formie przez około dwie godziny aż do odparowania - są praktycznie materiałami niechłonnymi i niezwilżalnymi. Drugą z tych właściwości poprawia zastosowanie żółci wołowej - kropla wody rozlewa się, tworząc plamę o średnicy nawet trzykrotnie większej od plamy utworzonej na powierzchni, której nie zwilżono tą substancją. Czas pozostawania kropli na przetartej żółcią wołową powierzchni jest również trzykrotnie krótszy - prawdopodobnie dlatego, że większa jest powierzchnia parowania wody. Mimo tak słabej chłonności i zwilżalności przyczepność powłok uzupełnienia akwarelowego i akrylowego do werniksowanej powierzchni kitu jest dość dobra. Problem może stanowić rozmywanie się powierzchniowej warstwy kitów podczas zakładania pędzlem werniksu, zawierającego benzynę lakową i olejek terpentynowy. Rozpuszczalniki te reaktywują nawet dobrze wyschnięty kit i mogą spowodować zniszczenie opracowanej faktury. W związku z tym konieczne jest unikanie rozpuszczalników alifatycznych 
i aromatycznych w czasie werniksowania czy zmywania wadliwych retuszy. Z racji niskiej chłonności wodnego spoiwa farb można zrezygnować ze stosowania werniksu retuszerskiego, natomiast werniks końcowy najbezpieczniej nanosić z rozpylacza.

Pozytywną stroną wrażliwości kitów na wymienione rozpuszczalniki jest możliwość łatwego ich usunięcia z ubytku, bez uszkodzenia otaczającej substancji. Odwracalność obu kitów, po przechowywaniu ich przez 5 miesięcy w skrajnych warunkach temperatury i wilgotności względnej powietrza, nie stanowi problemu. Kity pozostają miękkie i bardzo łatwo dają się usuwać mechanicznie za pomocą skalpela. Czynność tę dodatkowo jeszcze ułatwia lokalne rozgrzanie wypełnienia końcówką kautera. Niezwykle łatwo jest usunąć kity po zastosowaniu kompresów z benzyną lakową lub ksylenem. Rozpuszczalniki te reaktywują wyschnięte kity do stanu, w jakim były w chwili zakładania ich w ubytki. Dzięki temu możliwe jest także wykorzystanie kitów, z których - w wyniku złego przechowywania - wyparowały rozpuszczalniki, utrzymujące materiały w stanie plastyczności.

Odporność obu kitów na atak mikroorganizmów jest zróżnicowana. BEVA Gesso-P charakteryzuje się dość wysoką odpornością; obecność drobnoustrojów stwierdzono pod mikroskopem po 2 miesiącach przechowywania próbek w warunkach podwyższonej wilgotności względnej powietrza, a po upływie 6 miesięcy stopień rozwoju drobnoustrojów był nieznaczny, widoczny najwyraźniej w powiększeniu. BEVA Gesso- $V$ ma nieco niższą odporność na atak drobnoustrojów, który podobnie jak w przypadku BEVA Gesso-P nastapił po 2 miesiącach. Jednakże po upływie kolejnych 2 miesięcy pojedyncze kolonie mikroorganizmów były już dostrzegalne gołym okiem, a ich rozwój postępował tak, że po 6 miesiącach badań był znaczny, widoczny jako szary i czarny puszysty nalot.

Próbki kitów BEVA Gesso-P i BEVA Gesso- $V$ przechowywane przez 5 miesięcy w skrajnych warunkach temperatury i wilgotności względnej powietrza nie uległy widocznym zmianom, zniszczeniu czy utracie przyczepności do różnych rodzajów płócien. W przypadku kitów założonych w ubytkach destruktu obrazu stwierdzono jedynie nieznaczne zmatowienie warstwy werniksu i pojawienie się słabo widocznych zacieków o żółtawych brzegach pod wpływem działania wysokich temperatur (nie stwierdzono, czy źródłem zacieków był werniks damarowy, czy też kity - ich powierzchnia pozostała 
nienaruszona). Poza tym wypełnienia nie pekały od chwili założenia w ubytki, zachowały bardzo dobrą elastyczność oraz przyczepność do podłoża i do brzegów ubytków.

\subsection{Kit nr 6 - emulsyjny, tzw. „wiedeński”}

Badany kit miał następujący skład:

15\% roztwór wodny polialkoholu winylu - 1 cz. wag.,

$3 \%$ roztwór wodny metylocelulozy - 1 cz. wag.,

kreda szampańska - 3,5 cz. wag.,

25\% mastyks w olejku terpentynowym - 0,3 cz. wag.,

terpentyna wenecka $-0,15$ cz. wag.

Świeży materiał jest rzadką, dość płynną pastą o konsystencji przypominającej niezbyt gęstą śmietanę, o zapachu olejku terpentynowego i terpentyny weneckiej, białej barwie o ciepłym odcieniu. Barwienie masy jest możliwe przez zastapienie lub uzupełnienie białych wypełniaczy przez odpowiednie suche pigmenty. Kit może być aplikowany za pomocą szpachelek, skalpeli i łopatek, jak również pędzla. Po częściowym podeschnięciu możliwe jest odciskanie faktury na powierzchni kitu za pomocą negatywowych form z tworzyw sztucznych. Kit daje możliwości bardzo wyraźnego odwzorowania subtelnej, niezbyt głębokiej faktury, takiej jak splot płótna czy dukt pędzla. Po całkowitym wyschnięciu warstwy o grubości $0,5 \mathrm{~mm}$, trwającym około 150-180 min, powierzchnia kitu jest gładka, przypominająca nieco glazure, z nieznacznie odwzorowaną strukturą płótna. Po całkowitym wyschnięciu wypełnienie utworzone przez kit jest bardzo twarde, zwłaszcza w zewnętrznej warstwie. Wyrównywanie powierzchni i usuwanie nadmiarów jest w tym przypadku najskuteczniejsze na mokro, zwilżonym wodą korkiem lub drewnem balsa, ewentualnie na sucho przez zeskrobywanie ostrym skalpelem lub papierem ściernym.

Kit aplikowany nawet w znacznych grubościach kurczy się po wyschnięciu nieznacznie. Jednakże wysychanie grubszych wypełnień trwa stosunkowo długo. Mogą też wystąpić drobne spękania - niezależnie od grubości warstwy - które zarysowują się płytko na powierzchni, jednak ten mankament bez trudu może być zniwelowany podczas wyrównywania i szlifowania. 
Odczyn pH świeżej masy, jak również po jej wyschnięciu jest bardzo słabo zasadowy i wynosi odpowiednio 7,8 i 7,7 - nie stanowi więc zagrożenia dla podłoża płóciennego. Przyczepność wyschniętego kitu do nowego, przeklejonego metylocelulozą, jak również do przesyconego masą woskowo-żywiczną płótna jest bardzo dobra. Wartości liczbowe, określające siłę potrzebną do naderwania układu kit-płótno, wynoszą odpowiednio dla poszczególnych podłoży: 8,67 i 7,64 daN/ $\mathrm{cm}^{2}$. Podważanie i odrywanie kitu od płótna za pomocą skalpela przebiega z trudem i wymaga użycia znacznej siły. Elastyczność kitów przechowywanych w warunkach laboratoryjnych oraz w warunkach o podwyższonej temperaturze i obniżonej wilgotności względnej powietrza nie jest wysoka. Kit zawierający w swym składzie znaczne ilości żywic naturalnych jest twardy i stosunkowo sztywny. Jednakże nawilżanie w warunkach podwyższonej wilgotności względnej powietrza w poważny sposób poprawia te właściwość. Zdolność pochłaniania pary wodnej przez kit jest dość wysoka. Jego higroskopijność wynosi blisko 6,5\% i oprócz poprawiania elastyczności nie stwierdzono znaczącego wpływu tej właściwości na zmniejszanie odporności mechanicznej wypełnienia. Chłonność i zwilżalność kitu są dość dobre - kropla wody naniesiona na wyszlifowaną, nieizolowaną powierzchnię rozlewa się i wsiąka w głąb materiału. Werniks retuszerski jest również w znacznym stopniu wchłaniany w kit, który musi być kilkakrotnie naniesiony w celu uzyskania błyszczącej, zaizolowanej powierzchni. Warstwa werniksu w pewnym stopniu ogranicza chłonność, a przede wszystkim zwilżalność kitu przez wodne spoiwo retuszu. Właściwości te zdecydowanie poprawia (nawet w stosunku do nieizolowanej powierzchni) zastosowanie żółci wołowej. Kropla wody, pozostając dość długo na powierzchni, wnika jednak częściowo w głąb kitu, a częściowo odparowuje. Przyczepność powłok utworzonych przez farby akwarelowe oraz akrylowe do werniksowanej powierzchni kitu jest bardzo dobra.

Odporność kitu „wiedeńskiego” na atak mikroorganizmów jest średnia. Obecność drobnoustrojów stwierdzono pod mikroskopem po 2 miesiącach przebywania próbek w warunkach podwyższonej wilgotności względnej powietrza, po upływie 4 miesięcy nieznaczne zmiany w postaci pojedynczych kolonii były dostrzegalne nieuzbrojonym okiem, ale przez następne 2 miesiące stopień rozwoju drobnoustrojów nie zmienił się znacząco. 
Przechowywanie próbek kitu przez 5 miesięcy w skrajnych warunkach temperatury i wilgotności względnej powietrza nie spowodowało widocznych zmian w ich wyglądzie, kondycji i przyczepności do różnych rodzajów płócien. Podobnie było w przypadku kitów założonych w ubytkach destruktu obrazu.

Badania kitu pod kątem odwracalności na próbkach starzonych w skrajnych warunkach temperatury i wilgotności względnej powietrza wykazały, że jest ona osiaggalna za pomocą kilku środków. Najłatwiej jest usunąć kit po rozmiękczeniu go kompresami amoniakalnymi pozostawionymi na powierzchni przez około 30 minut. Nieco słabsze rezultaty dają też kompresy alkoholowe oraz wodne. Znaczna twardość materiału i jego bardzo dobra adhezja do płótna powodują, że bardzo trudne jest usunięcie kitu za pomocą skalpela. Mechanicznie można go dużo łatwiej rozkruszyć, używając mikrowiertarki elektrycznej.

\subsection{Kit nr 7 - modyfikowany klejowo-kredowy według Slanskiego}

Badany kit miał następujący skład:

10\% roztwór kleju króliczego - 1 cz. wag., wypełniacz - 3 cz. wag., o następującym składzie i proporcjach:

kreda szampańska + kreda bolońska - 3:1, terpentyna wenecka - 0,2 cz. wag.

Świeży kit jest gęstą, zwartą na skutek zżelowania masą, upłynniającą się do konsystencji niezbyt gęstej śmietany po ogrzaniu, o zapachu kleju glutynowego i terpentyny weneckiej, o białej barwie w ciepłym odcieniu. Barwienie w masie jest możliwe przez zastapienie lub uzupełnienie białych wypełniaczy suchymi pigmentami. Ogrzany kit może być aplikowany za pomocą szpachelek, skalpeli i łopatek, a po nieznacznym rozcieńczeniu wodą także pędzlem. Po cześciowym podeschnięciu możliwe jest odciskanie faktury na powierzchni kitu za pomocą negatywowych form z tworzyw sztucznych. Kit w ograniczonym zakresie daje możliwość odwzorowania niezbyt głębokiej faktury płótna czy duktu pędzla. Odciśnięcie mocniejszego opracowania malarskiego jest trudne, a efekt nie w pełni satysfakcjonujący. Po całkowitym wyschnięciu warstwy o grubości $0,5 \mathrm{~mm}$, trwającym około $150 \mathrm{~min}$, powierzchnia kitu jest 
gładka, nieco porowata, matowa, a wypełnienie przez niego utworzone jest twarde i sztywne. Wyrównywanie powierzchni jest możliwe na sucho, przez zeskrobywanie ostrym skalpelem lub papierem ściernym, a także na mokro zwilżonym wodą korkiem lub drewnem balsa. W przypadku niestabilnego, nieusztywnionego podkładką podłoża płóciennego już na tym etapie mogą wystąpić peknięcia w wypełnieniu. Kit aplikowany jednorazowo w warstwach o grubości do 3,0 mm po wyschnięciu kurczy się minimalnie lub wcale. Wysychaniu nawet grubszych warstw nie towarzyszą spękania. Zmiany objętości kitu zakładanego w cieńszych warstwach są praktycznie niezauważalne.

Odczyn pH preparatu zarówno przed związaniem, jak i po wyschnięciu jest bezpieczny dla podłoża płóciennego - wynosi odpowiednio 6,9 i 7,1 jest więc w obu przypadkach obojętny. Przyczepność wyschniętego kitu do nowego, przeklejonego metylocelulozą płótna jest dobra. Siła potrzebna do naderwania układu kit-płótno wynosi, co prawda, tylko 3,63 daN/ $\mathrm{cm}^{2}$, ale mechaniczne oderwanie kitu od płótna za pomocą skalpela przebiega z pewnym trudem. Znacznie słabsza jest adhezja kitu do płótna przesyconego masą woskowo-żywiczną $\left(2,71 \mathrm{daN} / \mathrm{cm}^{2}\right)$. Kit ten słabo zwilża płótno potraktowane tłustymi substancjami, w trakcie wysychania na nienaprężonym podłożu powstają deformacje, a nawet spekkania. Elastyczność kitu we wszystkich warunkach jest bardzo niska - nawet jego nawilżanie w warunkach podwyższonej wilgotności względnej powietrza nie wpływa na poprawę tej właściwości. Zdolność pochłaniania pary wodnej przez kit jest bardzo wysoka; jego higroskopijność wynosi blisko 9\% (jest to najwyższa wartość higroskopijności wśród przebadanych materiałów). Jest to niezwykle niepokojące, zwłaszcza gdy weźmie się pod uwage fakt niskiej odporności kitu na atak mikroorganizmów. Pojawienie się niewielkiego ogniska drobnoustrojów stwierdzono nieuzbrojonym okiem już po 16 dniach przebywania próbek w warunkach podwyższonej wilgotności względnej powietrza. Po upływie 6 miesięcy wzrost mikroorganizmów był obfity i obejmował 100\% powierzchni próbek. Świeża masa kitująca powinna być stosunkowo szybko wykorzystana, a przygotowana w większej ilości musi być przechowywana w lodówce, aby nie uległa zakażeniu mikroorganizmami.

Chłonność i zwilżalność kitu są bardzo dobre - kropla wody naniesiona na wyszlifowaną, nieizolowaną powierzchnię rozlewa się szeroko i wsiąka w głąb kitu przed upływem 30 minut. Izolowanie powierzchni werniksem 
retuszerskim damarowym i akrylowym przebiega bez większych problemów. Równomiernie błyszczącą powierzchnię można już uzyskać po dwukrotnym naniesieniu werniksu. Podobnie jak w poprzednich przypadkach, warstwa werniksu w poważnym stopniu ogranicza chłonność i zwilżalność kitu przez wodne spoiwo farb - następuje częściowe odparowanie wody z powierzchni. Podobnie też jak w omawianych wyżej materiałach, sytuację zdecydowanie poprawia zastosowanie żółci wołowej. Przyczepność powłok utworzonych przez farby akwarelowe i akrylowe do werniksowanej powierzchni kitu jest dobra.

Przechowywanie próbek kitu przez 5 miesięcy w skrajnych warunkach temperatury i wilgotności względnej powietrza nie spowodowało widocznych zmian w ich wyglądzie, kondycji i przyczepności do różnych rodzajów płócien. Nieco inaczej wygląda sytuacja w przypadku kitów założonych w ubytkach destruktu obrazu. Już od chwili wysychania kit sprawiał poważne problemy: mimo kilkakrotnego zakładania, szczególnie w większych ubytkach, wypełnienie przejawiało tendencje do pekania. Prawdopodobnie ma ona związek z niską zwilżalnością przesyconego masą woskowo-żywiczną płótna przez świeży kit, słabym jego przylgnięciem oraz niską elastycznością. Po 5 miesiącach badań stwierdzono nieznaczne poszerzenie się pęknięć i uniesienie krawędzi poszczególnych poletek kitu.

Odwracalność, badana na próbkach starzonych przez 5 miesięcy w skrajnych warunkach temperatury i wilgotności względnej powietrza, jest najłatwiej osiągalna za pomocą kompresów wodnych i amoniakalnych pozostawionych na powierzchni przez 15-30 minut. Usunięcie kitu jest też nieznacznie łatwiejsze po zastosowaniu kompresu alkoholowego. Z powodu znacznej twardości materiału bardzo trudne jest usunięcie kitu za pomocą skalpela. Użycie mikrowiertarki elektrycznej umożliwia jego łatwiejsze rozkruszenie.

\section{Wnioski końcowe}

Celem pracy było przebadanie i ukazanie szerokiej gamy właściwości wybranych materiałów, które są stosowane lub mogą być potencjalnie przydatne do uzupełniania ubytków zapraw w malowidłach sztalugowych na płótnie.

Badania nowych i tradycyjnych materiałów, ukazujące i porównujące ich właściwości, pozwalają na ujawnienie ich wad i zalet oraz na poszerzenie 
spektrum możliwości, będących w zasięgu konserwatora-restauratora dzieł sztuki, nie moga jednak wskazywać optymalnych czy uniwersalnych metod i środków. Często podkreślany jest fakt niemożności stworzenia i funkcjonowania idealnej receptury, która pozwoliłaby na zastosowanie sporządzonego według niej kitu we wszystkich - nierzadko skrajnie odmiennych - przypadkach, wymagających zarówno innej metody, jak i innego środka. Różne wymagania dyktowane przez rozmaite obrazy narzucają w praktyce zasade indywidualnego podejścia do każdego jednostkowego przypadku. Także zadaniem niniejszej pracy nie było wskazanie idealnego materiału, a jedynie poszerzenie wiedzy i zasobu środków dostępnych dla konserwatora. Żaden z przebadanych materiałów nie może być uznany za uniwersalny i odpowiadający wszystkim wymaganiom, jakie stawia się materiałom służącym do uzupełniania ubytków. Jednakże znając ich właściwości, można w pełni odpowiedzialnie dokonywać wyboru środka najbardziej odpowiedniego dla konserwowanego obrazu, eliminując te z nich, które mają trudne do usunięcia wady, mogące być przyczyną późniejszych problemów, lub wręcz stanowić zagrożenie dla obrazu.

Gotowe, firmowe materiały stanowią duże ułatwienie w pracy konserwatora, ale ich wybór nie może być przypadkowy i bezkrytyczny, nawet jeśli są polecane przez producentów jako materiały profesjonalne (co zresztą niekiedy znajduje potwierdzenie w późniejszej praktyce). Wyniki badań pięciu materiałów fabrycznych pokazały, jak różnorodne właściwości mogą mieć wykonane z nich wypełnienia ubytków. Ocenę umożliwia w tym przypadku zestawienie i porównanie tych produktów ze sobą. Spośród pięciu gotowych kitów na szczególną uwage zasługują trzy: BEVA® Gesso-P, BEVA® Gesso-V oraz Modostuc, które spełniają większość wymagań stawianych materiałom do uzupełnień ubytków zapraw.

Niezwykle cenną właściwością wypełnień wykonanych z dwóch pierwszych spośród wyżej wymienionych preparatów jest ich bardzo wysoka elastyczność, brak skurczu i spekań nawet w jednorazowo aplikowanych grubych warstwach oraz rozległych ubytkach. Pięciomiesięczny okres starzenia w skrajnych warunkach temperatury i wilgotności względnej powietrza nie spowodował zniszczenia czy niepokojących zmian wypełnień. Odwracalność tych materiałów jest łatwo osiagalna za pomocą stosunkowo prostych metod i łagodnych środków. Warto podkreślić również to, że w przypadku płócien 
wrażliwych na wilgoć kity te mogą okazać się niezastąpione. Bardziej przydatny do zastosowania w konserwacji malarstwa na płótnie wydaje się kit BEVA Gesso-P o większej plastyczności, zawierający drobniejszy, lepiej sklejony wypełniacz. Ten bardzo dobry preparat nie jest niestety pozbawiony wad. Najpoważniejszymi z nich są niechłonność i słaba zwilżalność przez wodne spoiwo retuszu, a także możliwość uszkodzenia opracowanej powierzchni wypełnienia podczas werniksowania lub zmywania uzupełnień barwnych benzyną lakową czy ksylenem. Nie są to jednak mankamenty, które dyskwalifikują ten materiał, gdyż znając zagrożenia, można im zaradzić (zwilżalność można poprawić, stosując odpowiednie substancje, np. żółć wołową, spoiwo wodne farb zastąpić odpowiednio dobranym rozpuszczalnikowym, werniks może być nanoszony z rozpylacza).

Trzeci z wymienionych materiałów - kit Modostuc - ma wiele właściwości porównywalnych ze sprawdzonym w praktyce kitem „wiedeńskim” (higroskopijność, chłonność, zwilżalność, przyczepność powłok barwnych uzupełnień, łatwość użycia), tworzy jednak bardziej miękkie, plastyczne, łatwiejsze w obróbce i bardziej elastyczne wypełnienia, jest też łatwiejszy do usunięcia z ubytku. Jednakże jego wytrzymałość mechaniczna i stopień sklejenia wypełniacza mogą być w niektórych przypadkach niewystarczające. Ponadto nie może być zakładany w grubszych warstwach, gdyż podlega wówczas podczas wysychania znacznemu skurczowi oraz pekaniu w całej masie. W przypadku głębokich wypełnień konieczne jest zakładanie kilku warstw kitu.

Pozostałym dwóm preparatom - Tikkurila i Italstucco - nie można wystawić tak pozytywnej oceny, jednakże w każdym przypadku decydują o tym inne czynniki. Kit Tikkurila tworzy bardzo twarde wypełnienia, mocno przywierające do podłoża i brzegów ubytków. Stopień twardości można porównać do twardości kitu „wiedeńskiego”, jednakże o ile w tym drugim przypadku można ją regulować stężeniem spoiw, ilością żywic naturalnych i wypełniacza, o tyle w przypadku kitu Tikkurila mamy do czynienia z gotowym, optymalnie skomponowanym produktem. Umieszczenie bardzo twardego wypełnienia w sąsiedztwie delikatnych, kruchych warstw oryginalnych, opracowywanie go i ewentualne późniejsze usunięcie stanowi dla nich potencjalne zagrożenie. Firmowy kit o zwartej i bardzo gestej konsystencji ma także tendencje do gęstnienia i dalszego twardnienia (aż do postaci twardej bryły) podczas dłuższego przechowywania w raz otwartej oryginalnej puszce. 
Ponadto kit zakładany w grubszych warstwach znacznie się kurczy i pęka. Kłopotliwa może być duża chłonność wypełnienia i problemy z uzyskaniem dobrze zaizolowanej werniksem powierzchni (konieczne jest wielokrotne powtarzanie zabiegu). Niepokojąca jest też wysoka higroskopijność kitu, z którą wiąże się znaczne osłabienie odporności mechanicznej wypełnienia. Ta ostatnia wada jest również charakterystyczna dla kitu Italstucco, mimo że jego higroskopijność jest niższa o 3\% w stosunku do kitu Tikkurila. Jednakże nawet $\mathrm{w}$ warunkach powietrzno-suchych wypełnienia utworzone przez Italstucco są bardzo miękkie, o niskiej odporności mechanicznej. Także skurcz i pekanie kitu naniesionego w grubszych warstwach są poważne. W badaniach odporności na starzenie w skrajnych warunkach temperatury i wilgotności kit Italstucco wypadł najsłabiej - wypełnienia popękały. Ponadto jego nadmierna chłonność praktycznie uniemożliwia zaizolowanie wypełnienia pod uzupełnienie barwne - praktycznie dopiero przesycenie go werniksem przez kilkunastokrotne nanoszenie go daje efekt możliwy do przyjęcia, ale jest to już wówczas kit o innym charakterze niż materiał wyjściowy. Kit ten, wobec powyższego, nie jest materiałem odpowiednim do uzupełniania ubytków zaprawy w malarstwie sztalugowym na płótnie.

W odniesieniu do kitów sporządzanych według receptur trzeba podkreślić, że dbałość o dobór najlepszych gatunkowo składników ma zasadnicze znaczenie dla właściwości finalnego produktu. Dotyczy to zarówno spoiw naturalnych i sztucznych, jak i wypełniaczy. Wykorzystując do badań recepturę kitu emulsyjnego „wiedeńskiego”, powszechnie stosowaną w tym czasie, stwierdzono, że jej zmodyfikowanie i dopracowanie może w znacznym stopniu wyeliminować problemy, jakie były sygnalizowane dotychczas przez konserwatorów. Już podstawowa receptura kitu „wiedeńskiego” daje szerokie możliwości uzyskiwania produktów różnorodnych pod względem właściwości. Zastąpienie kredy szampańskiej pigmentami - np. syntetyczną czerwienią żelazową - nawet przy ścisłym zachowaniu proporcji - da w efekcie wypełnienie twardsze, mniej elastyczne i bardziej chłonne, trudniejsze do zaizolowania werniksem. Jako wypełniacz powinien być stosowany materiał tłusty, dajacy elastyczne wypełnienia - dobra gatunkowo kreda, bolus biały, kaolin lub w przypadku pigmentów naturalne tłuste glinki (ugry, sieny, puccole). Nie należy też nadużywać ilości dodawanych żywic naturalnych, które wpływają na twardość i sztywność wypełnienia w warunkach 
powietrzno-suchych. Funkcjonujący w recepturze zakres proporcji mastyksu w olejku terpentynowym i terpentyny weneckiej może być zawężony do niewielkiej ilości, co zmniejszy nadmierną twardość kitu po wyschnięciu. Warto też zwrócić uwage na stężenie spoiw, w tym głównie polialkoholu winylu. W recepturze, gdzie zamiennie funkcjonowała żelatyna i polialkohol winylu, nie wprowadzono rozróżnienia stężeń dla obu spoiw. A tymczasem 15\% żelatyna i 15\% polialkohol winylu nie są spoiwami o identycznej sile klejenia i elastyczności. Jak wiadomo, 15\% PAW jest już bardzo silnym klejem, dającym wypełnienia nazbyt twarde i o zaledwie dostatecznej elastyczności. Przeprowadzone badania pokazały, że 15\% stężenie PAW w kicie „wiedeńskim” jest zbyt wysokie - należy pamiętać, że sporządzając kit, dodatkowo stosujemy jeszcze 3\% metyloceluloze, co zapewni odpowiednie sklejenie wypełniaczy. W tej sytuacji wydaje się uzasadnione obniżenie stężenia polialkoholu winylu do 7-10\% (niższe dla rzadszych kitówek, wyższe dla gęstych szpachlówek), wykorzystywanego do przygotowania kitu „wiedeńskiego”.

Kit klejowo-kredowy modyfikowany ma kilka zalet porównywalnych z pozostałymi kitami lub niekiedy je przewyższających, jak choćby wysychanie bez skurczu i spękań nawet w grubszych warstwach czy odpowiednia chłonność i zwilżalność przez wodne spoiwo farb, aczkolwiek inne jego właściwości budzą niepokój i uniemożliwiają wystawienie pozytywnej oceny. Najpoważniejszą wadą wypełnień utworzonych przez ten kit jest niska elastyczność i znaczna sztywność, która jest stała i niezmienna, mimo że charakteryzuje się on bardzo wysoką higroskopijnością. Ta cecha jest w tym przypadku niepożądana z powodu obniżania, i tak już niskiej, odporności kitu na atak mikroorganizmów. Słaba zdolność zwilżania przewoskowanych podobrazi, niska odporność na urazy mechaniczne, sztywność, pojawiające się tendencje do pekania na niektórych typach płótna bardzo niekorzystnie wpływają na przydatność kitu do uzupełniania ubytków zaprawy na płótnie. W tym przypadku niezbędne sa próby zmian proporcji składników, które uczyniłyby go bardziej elastycznym i odpowiednim dla podłoża, podlegającego poważnym ruchom związanym z pracą płótna, a także z czynnościami koniecznymi w procesie konserwacji. Przypadek tego kitu jeszcze raz potwierdza przekonanie o potrzebie dostosowania materiału do obiektu; to, co dobre i zdające egzamin na podłożu drewnianym, dla którego skład kitu został sformułowany, niekoniecznie będzie odpowiednie i sprawdzi się również 
dla podobrazia płóciennego. Niezależnie więc od oceny wystawionej materiałom, każdorazowo decyzja o zastosowaniu konkretnego środka musi być poprzedzona wstępnymi próbami podstawowych właściwości (elastyczności, twardości, stopnia sklejenia, zwilżalności itp.). Jest to tym bardziej istotne, że poszczególne partie materiałów w przypadku gotowych produktów mogą różnić się między sobą i wymagać zmodyfikowania - co staje się możliwe dzięki znajomości ich składu.

Wykonane badania, mimo że poszerzają spojrzenie na wybrane materiały firmowe, z pewnością nie wyczerpują wszystkich, związanych z nimi zagadnień. Niemniej jednak, jeśli przytoczone wyniki i wnioski z nich płynące znajdą zastosowanie w praktyce konserwatorskiej, spełnią swoje cele. Oferty producentów nieustannie ulegają zmianom, na rynku pojawiają się wciąż nowe preparaty. Warunkiem korzystania z ułatwień powinna być wiedza o właściwościach tych materiałów. Kierowanie się przy wyborze środków dostępnością i łatwością użycia nie może być jedynym ani głównym kryterium branym pod uwage, gdyż decyzja ta może zaważyć na dalszej kondycji powierzonych w ręce konserwatora-restauratora pamiątek przeszłości. Odpowiedzialność za nie i troska o przekazanie ich następnym pokoleniom są wystarczającymi powodami, aby powstrzymać się przed użyciem przypadkowych, niesprawdzonych środków na każdym etapie konserwacji i restauracji dzieła sztuki. 

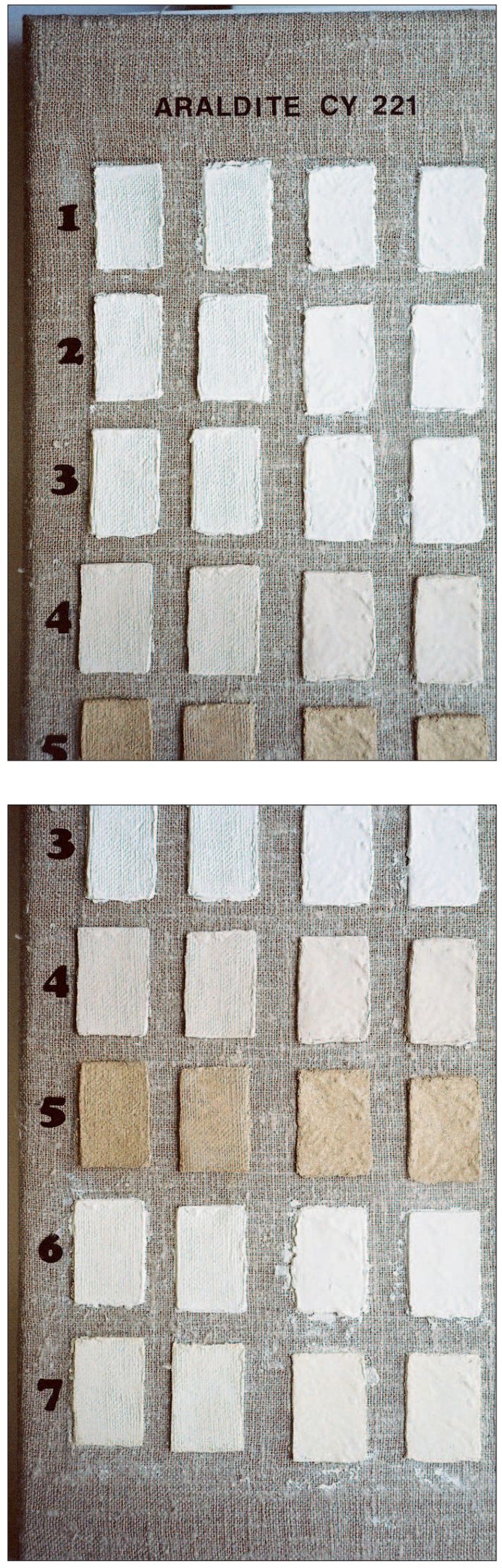

Il. 1. Próbki kitów: 1 - Tikkurila, 2 -Italstucco, 3 - Modostuc i 4 - BEVA Gesso-P z fakturami odciśniętymi za pomocą negatywowych form z Araldite CY 221, z odwzorowaniem splotu płótna i opracowania malarskiego (wszystkie fot. wykonała autorka)

Il. 2. Próbki kitów: $4-B E V A$

Gesso-P, 5 - BEVA Gesso-V, 6 - emulsyjnego „wiedeńskiego” i 7 - klejowo-kredowego modyfikowanego z fakturami odciśniętymi za pomoca negatywowych form z Araldite CY 221, z odwzorowaniem splotu płótna i opracowania malarskiego 

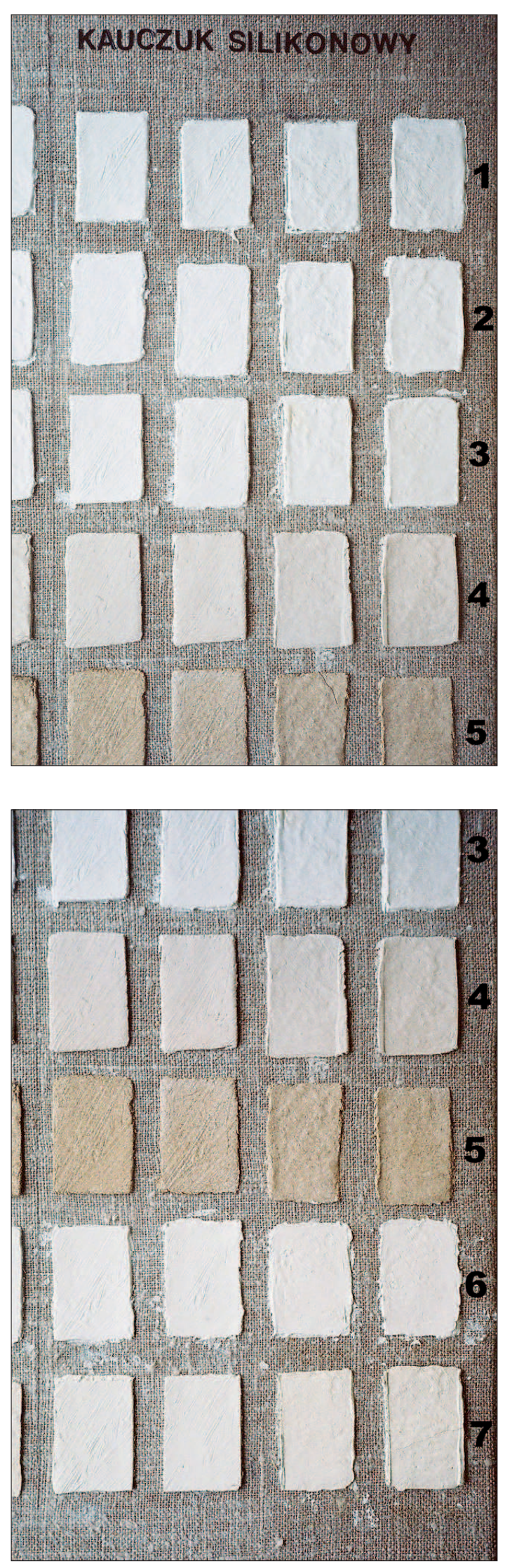

Il. 3. Próbki kitów: 1 - Tikkurila, 2 -Italstucco, 3 - Modostuc i 4 - BEVA Gesso-P z fakturami odciśniętymi za pomoca negatywowych form z kauczuku silikonowego Polastosil M-69, z odwzorowaniem splotu płótna i opracowania malarskiego

Il. 4. Próbki kitów: $4-B E V A$

Gesso-P, 5 - BEVA Gesso-V, 6 - emulsyjnego „wiedeńskiego” i 7 - klejowo-kredowego modyfikowanego z fakturami odciśniętymi za pomoca negatywowych form z kauczuku silikonowego Polastosil M-69, z odwzorowaniem splotu płótna i opracowania malarskiego 


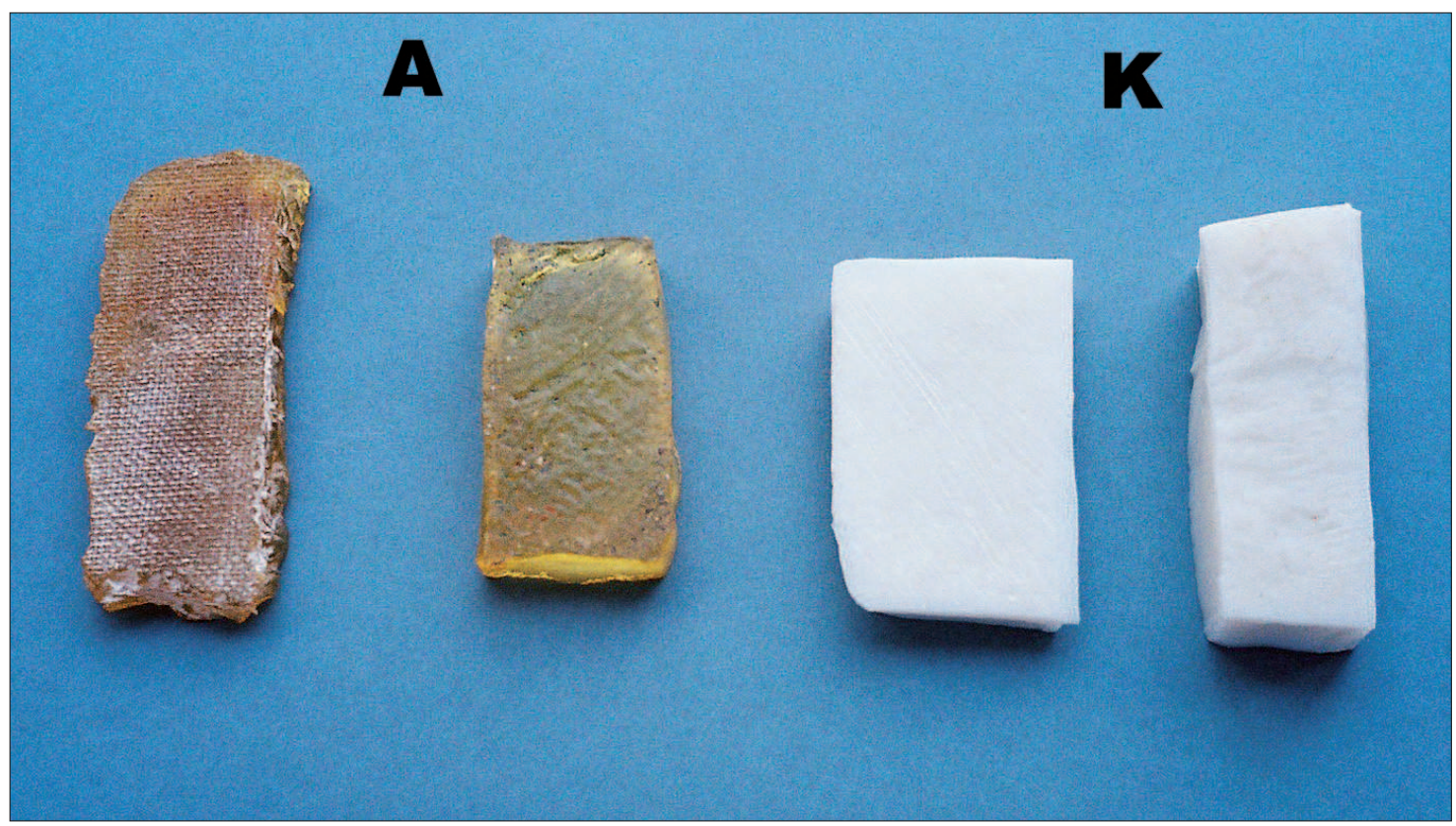

Il. 5. Formy negatywowe użyte do odciskania faktury na powierzchni kitów: oznaczenie A (po lewej) z Araldite CY 221, oznaczenie K (po prawej) z kauczuku silikonowego Polastosil M-69

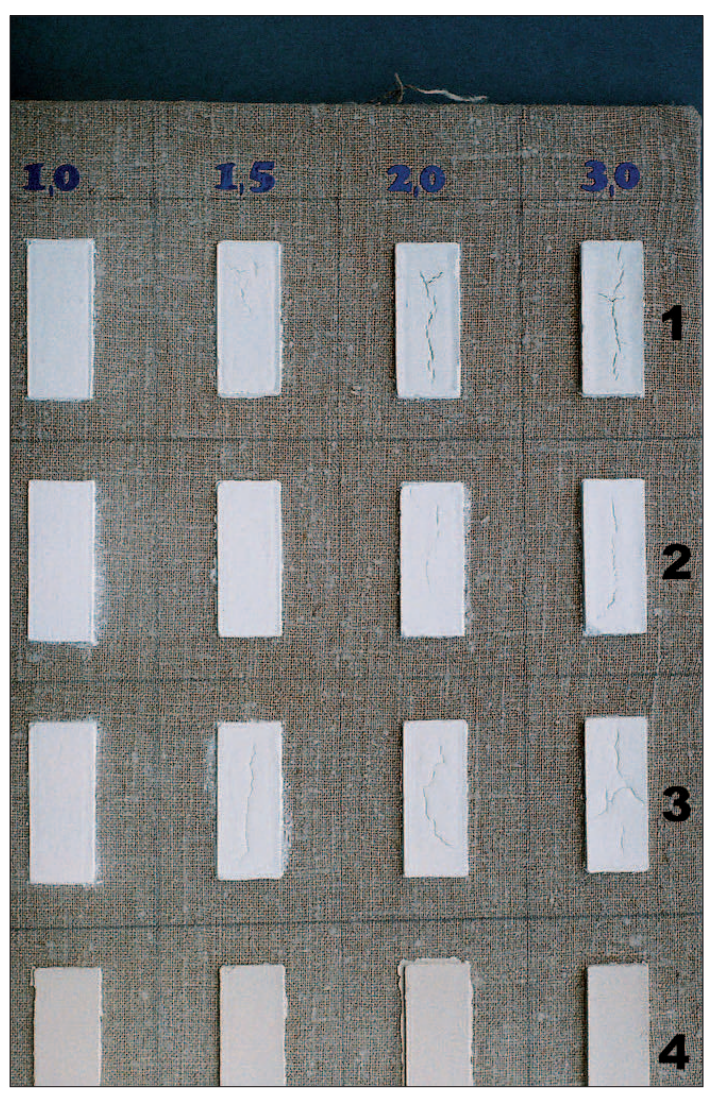

Il. 6. Badania występowania skurczu i spękań w kitach aplikowanych w różnych grubościach. Próbki kitów o grubościach od 1,0 do 3,0 mm: 1 - Tikkurila, 2 - Italstucco i 3 - Modostuc, wysychających ze znacznym skurczem i towarzyszącymi mu wielokierunkowymi, szerokimi spekaniami w całej masie 


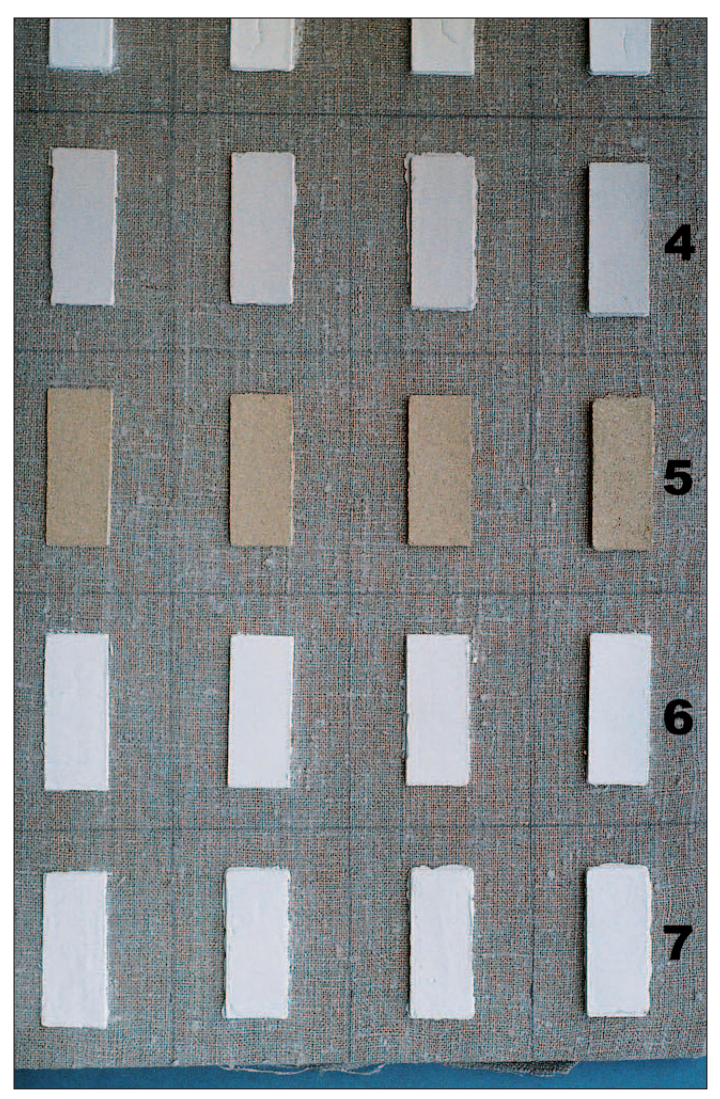

Il. 7. Badania wystepowania skurczu i spękań w kitach aplikowanych w różnych grubościach. Próbki kitów o grubościach od 1,0 do 3,0 mm: 4 - BEVA Gesso-P, 5 - BEVA Gesso-V, 6 - emulsyjnego „wiedeńskiego” i 7 - klejowo-kredowego modyfikowanego, wysychających z minimalnym skurczem i bez spękań (tylko kit „wiedeński” nieznacznie powierzchniowo spekał)

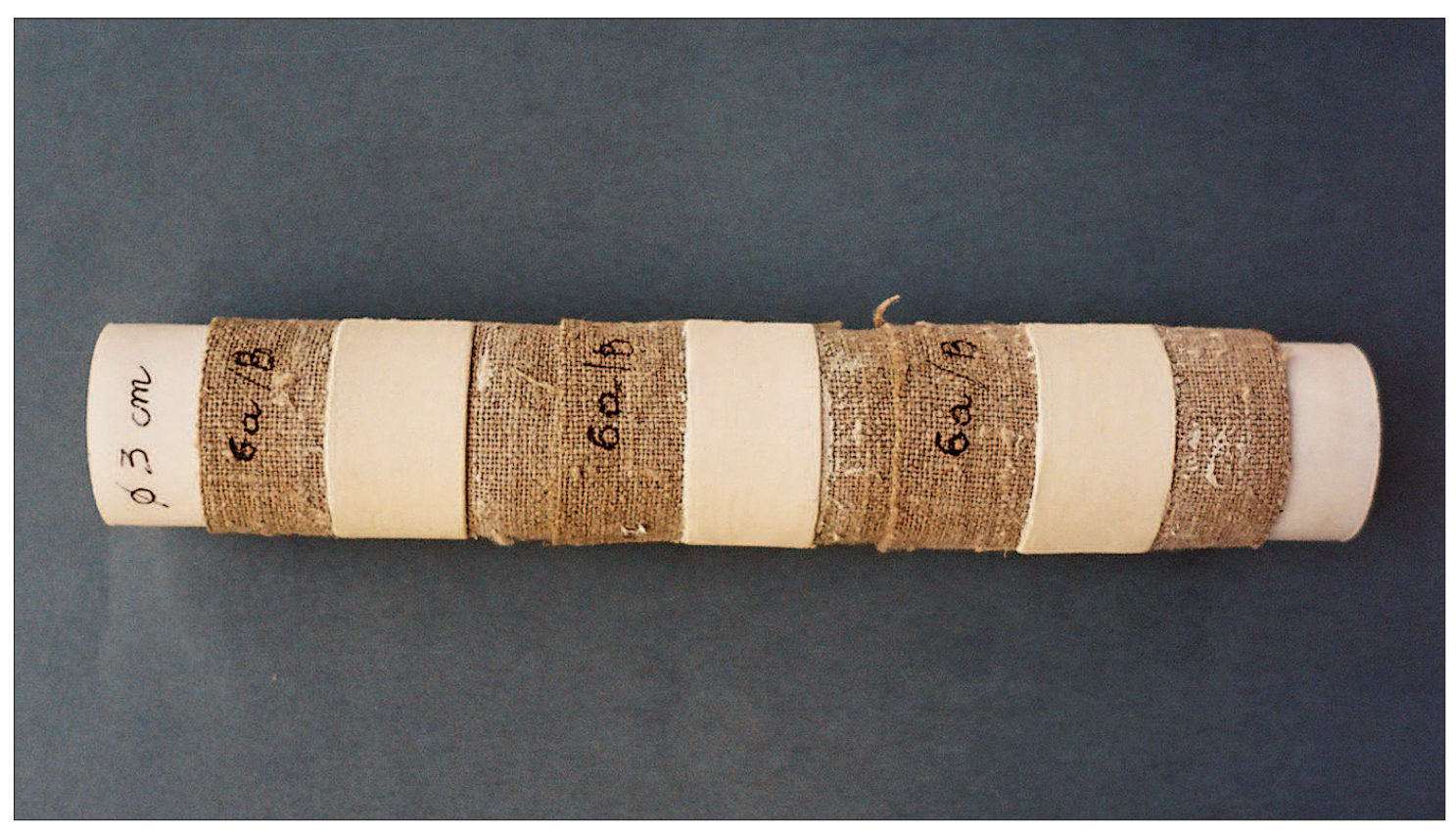

Il. 8. Badania elastyczności kitów: próbki kitu emulsyjnego „wiedeńskiego” (wariant z najmniejszą ilością żywic naturalnych) po nawilżaniu i wygięciu na walcu o średnicy 3,0 cm - widoczny brak spękań 


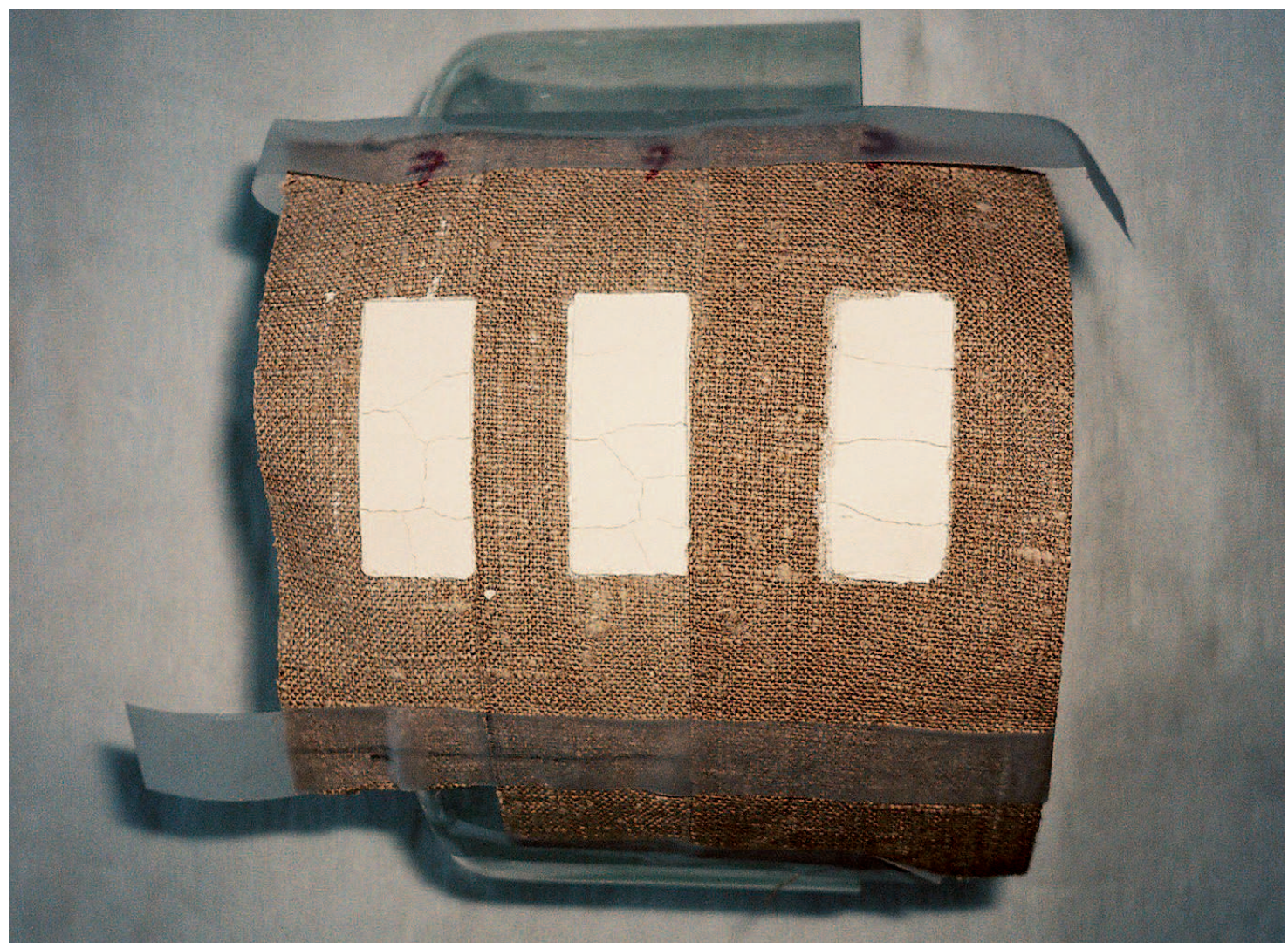

Il. 9. Badania elastyczności kitów: próbki kitu klejowo-kredowego modyfikowanego po nawilżaniu i wygięciu na walcu o średnicy 19,0 cm - widoczne wielokierunkowe spękania

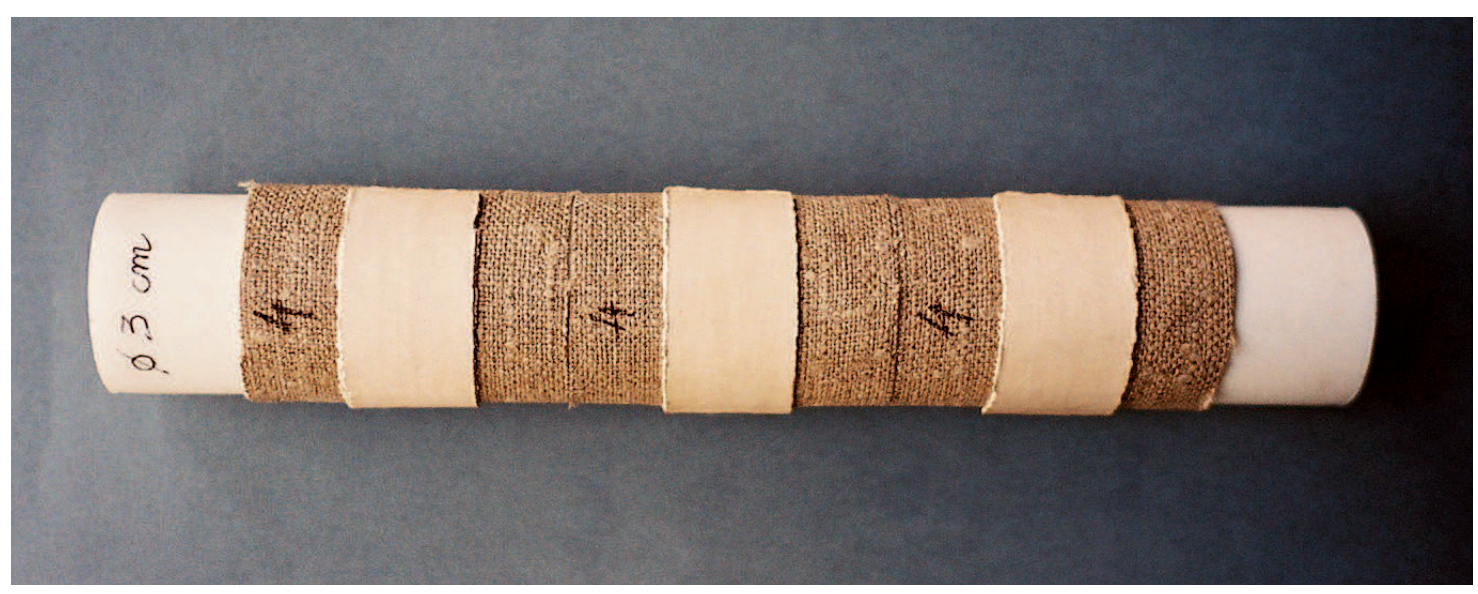

Il. 10. Badania elastyczności kitów: próbki kitu BEVA Gesso-P po przesuszeniu w suszarce i wygięciu na walcu o średnicy 3,0 cm - widoczny brak spękań 


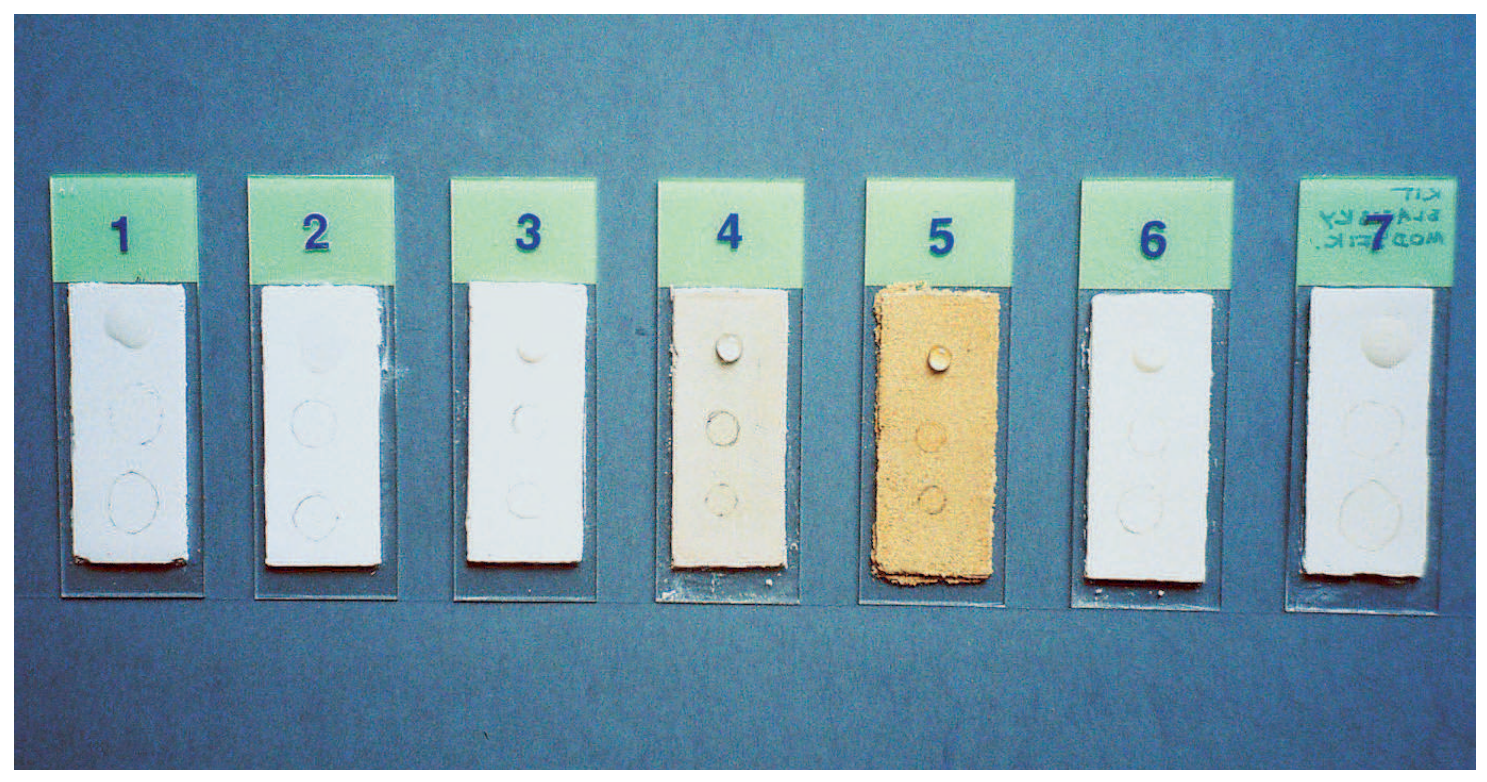

Il. 11. Badania chłonności i zwilżalności kitów wyszlifowanych nieizolowanych; wygląd i zakres rozprzestrzeniania się kropli wody na powierzchni kitów

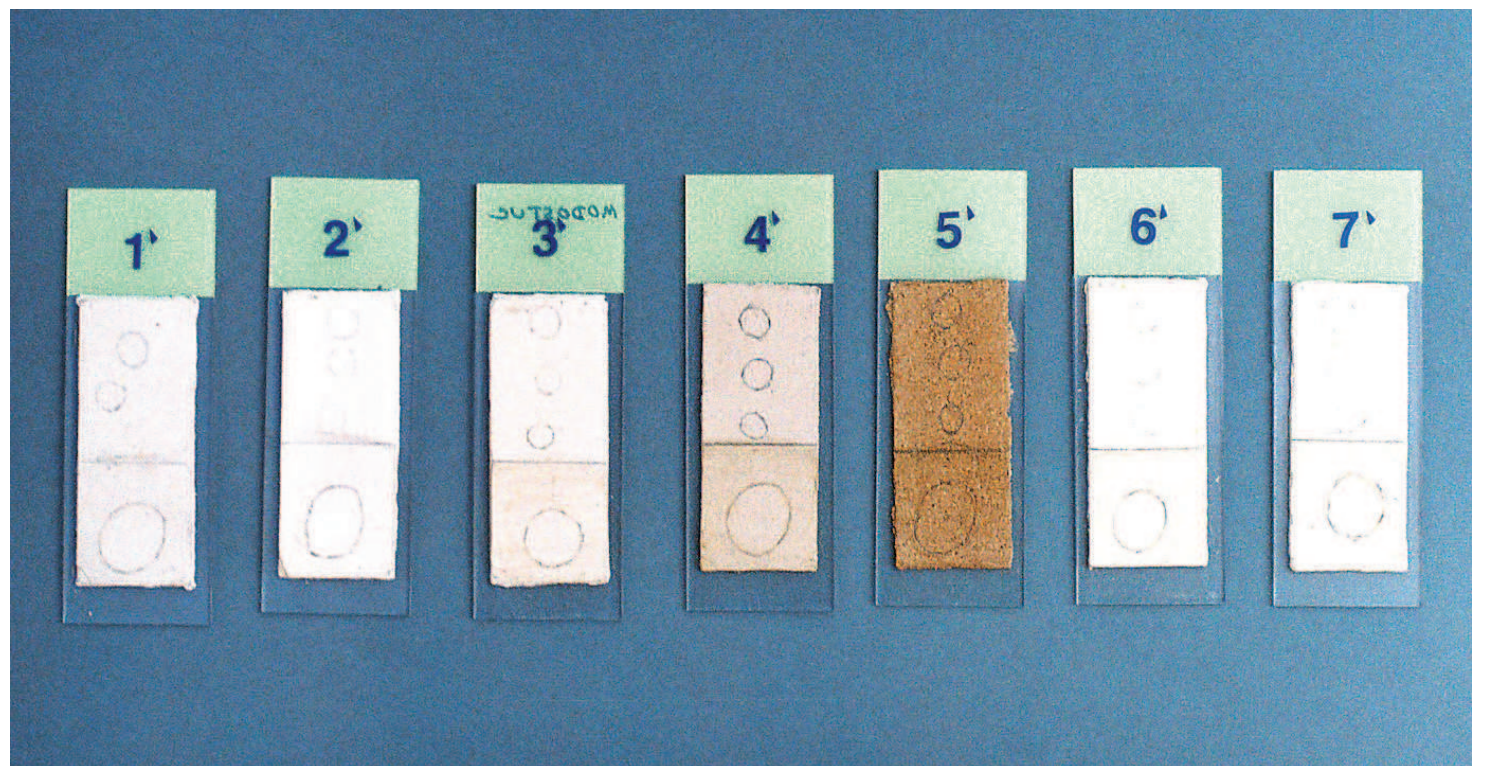

Il. 12. Badania chłonności i zwilżalności kitów wyszlifowanych, izolowanych werniksem retuszerskim damarowym (nad kreską) i zwilżonych żółcią wołową (pod kreską); zakres rozprzestrzeniania się kropli wody na powierzchni kitów 

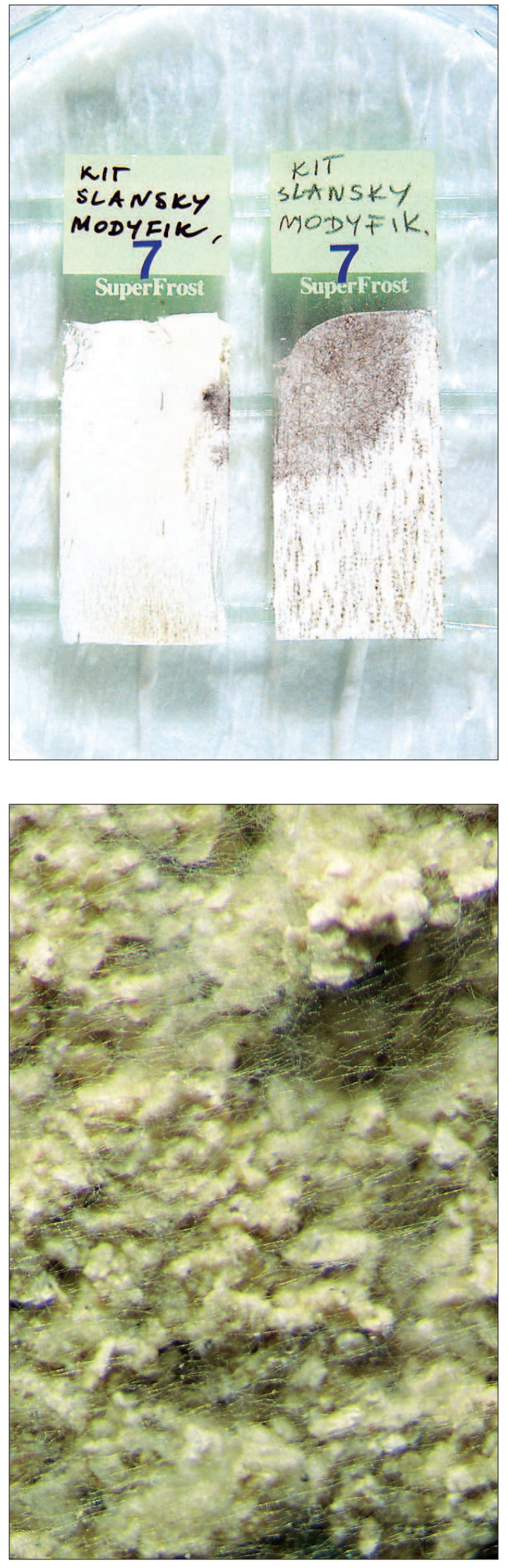

Il. 13. Badania odporności kitów na atak mikroorganizmów w warunkach podwyższonej wilgotności względnej powietrza; próbki kitu klejowo-kredowego modyfikowanego po upływie sześciu miesięcy, z widocznymi zmianami spowodowanymi przez drobnoustroje

Il. 14. Badania odporności kitów na atak mikroorganizmów w warunkach podwyższonej wilgotności względnej powietrza; makrofotografia próbki kitu BEVA Gesso-V po sześciu miesiącach badań - widoczna gęsta siatka srebrzystych nitek grzybni 

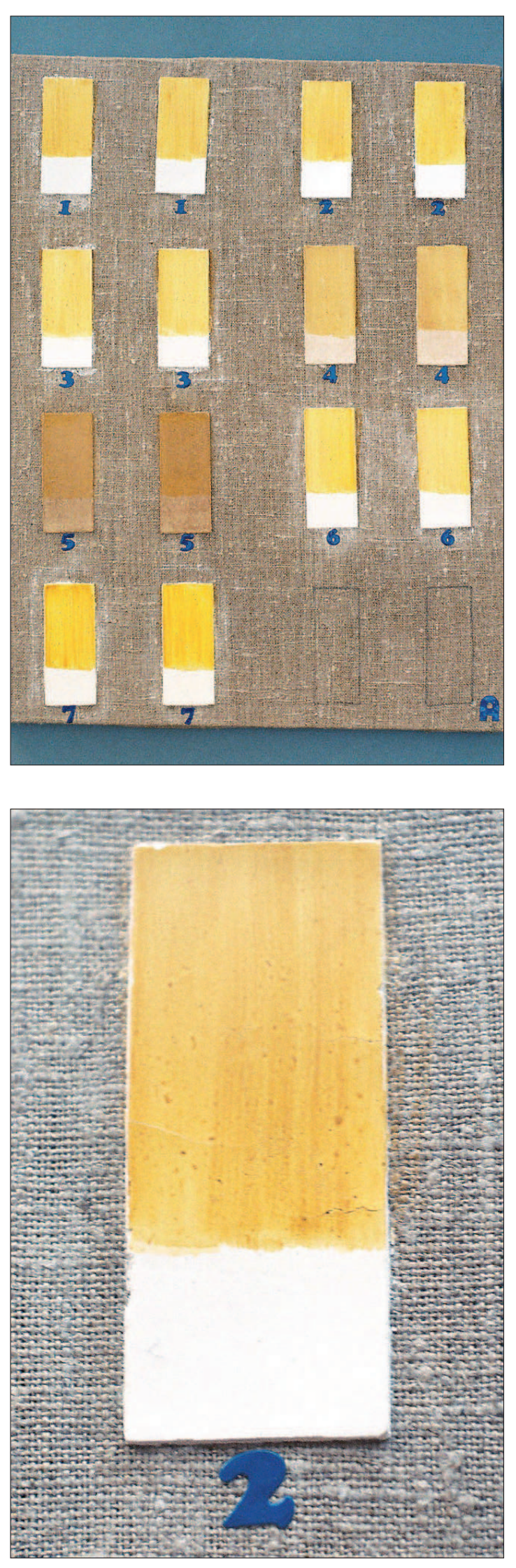

Il. 15. Próbki kitów naniesione na nowe płótno - po pięciu miesiącach badania odporności kitów na starzenie w skrajnych warunkach temperatury i wilgotności względnej powietrza

\section{Il. 16. Próbka kitu Italstucco}

z widocznymi spekaniami, powstałymi po pięciu miesiącach badania odporności kitów na starzenie w skrajnych warunkach temperatury i wilgotności względnej powietrza 


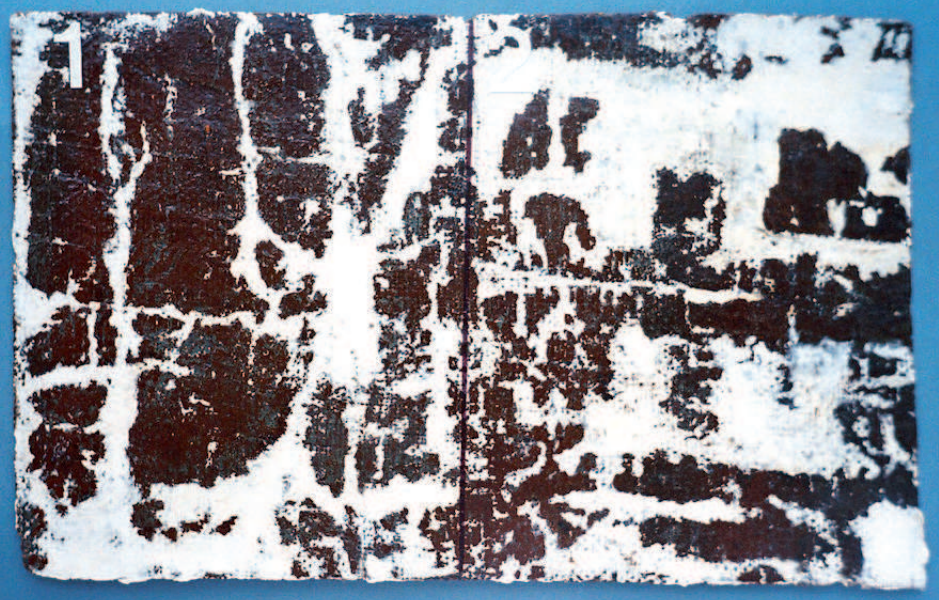

I1. 17. Fragment destruktu obrazu z kitami 1 - Tikkurila (po lewej) i 2 - Italstucco (po prawej) założonymi w ubytki zaprawy - po pięciu miesiącach badania odporności kitów na starzenie w skrajnych warunkach temperatury i wilgotności względnej powietrza

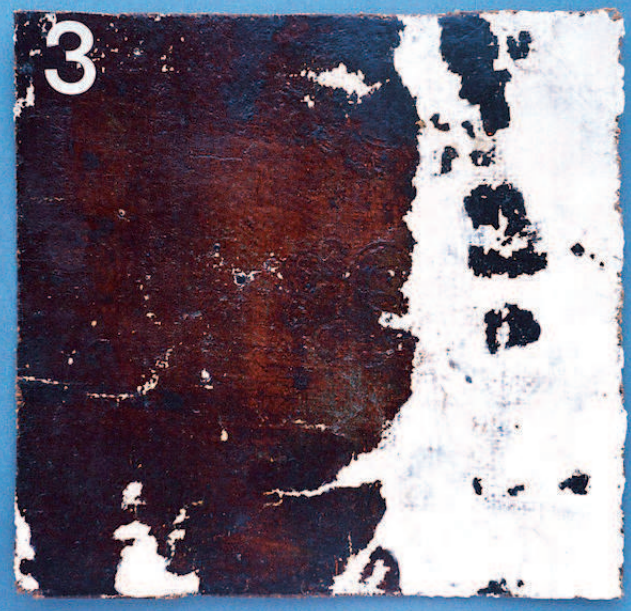

Il. 18. Fragment destruktu obrazu z kitem 3 - Modostuc założonym w ubytki zaprawy - po pięciu miesiącach badania odporności kitów na starzenie w skrajnych warunkach temperatury i wilgotności względnej powietrza 


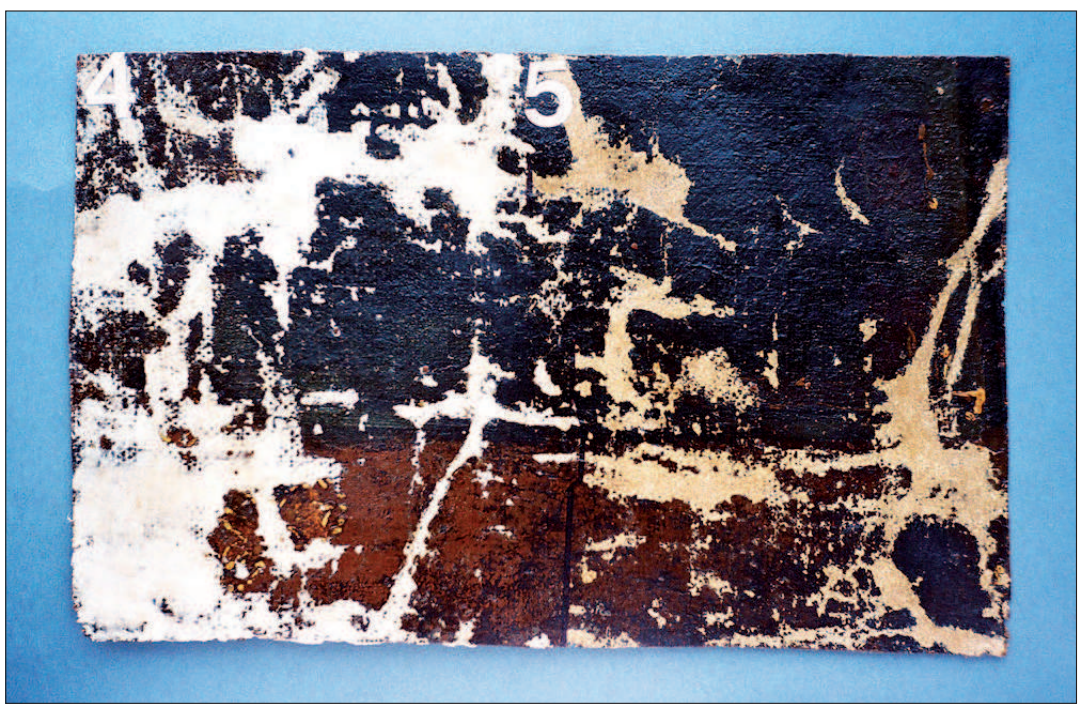

Il. 19. Fragment destruktu obrazu z kitami 4 - BEVA Gesso-P (po lewej) i 5 - BEVA Gesso-V (po prawej) założonymi w ubytki zaprawy - po pięciu miesiącach badania odporności kitów na starzenie w skrajnych warunkach temperatury i wilgotności względnej powietrza

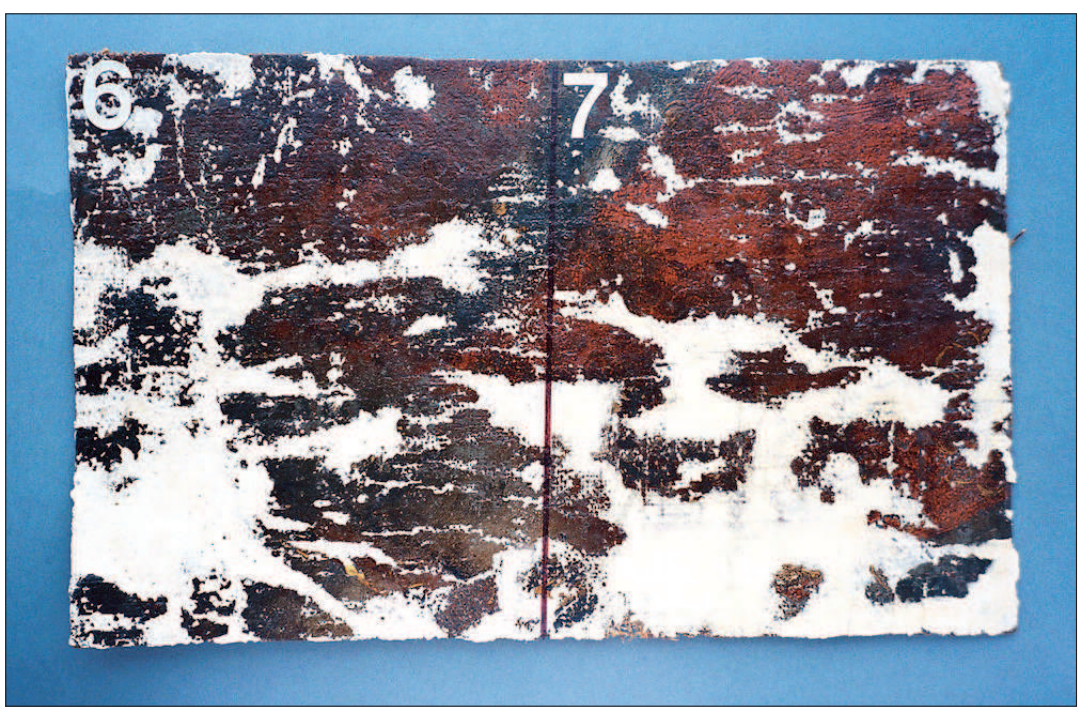

Il. 20. Fragment destruktu obrazu z kitami 6 - emulsyjnym „wiedeńskim” (po lewej) i 7 - klejowo-kredowym modyfikowanym (po prawej) założonymi w ubytki zaprawy - po pięciu miesiącach badania odporności kitów na starzenie w skrajnych warunkach temperatury i wilgotności względnej powietrza 


\section{Summary}

\section{Research on the materials used for reintegration of the injuries of priming in paintings on canvas}

The paper presents the description and results of the research on materials used or potentially suitable for reintegration of the injuries of priming in paintings on canvas. Five ready-made brand products have been tested and compared them with two products made by the recipes aiming for determination of their physical and chemical properties as well as suitability in conservation of easel paintings on canvas supports.

The following research procedures were followed: the analysis of chemical composition - using Differential Thermal Analysis (DTA) as well as IR-spectroscopy; the evaluation of preparation, application and other of handling properties; suitability for imprinting the texture on the surface of filling using negative moulds of artificial resins; evaluation of shrinkage and cracking during drying of the material applied to canvas support; the adhesion to canvas sized with methyl cellulose and saturated with bees-wax-and resin mixture; determination of $\mathrm{pH}$ of fresh, cured and aged materials; elasticity of fillings on canvas bent on cylinders of various diameter in different humidity and temperature conditions; hygroscopic properties in high humidity atmosphere; absorbability and wettability of the filling surface with aqueous binding media of paints; adhesion of layers of paints with water-based media resistance to biodegradation in high humidity atmosphere; ageing resistance in extreme air temperature and humidity; reversibility - the possibility to remove the fillings after several months of aging in extreme air temperature and humidity with mechanical and chemical methods. 